Prepared for the U.S. Department of Energy

under Contract DE-AC05-76RL01830

\title{
Commissioning an Engineering Scale Coal Gasifier
}

\author{
D Reid JE Cabe \\ MD Bearden
}

July 2010

\section{Pacific Northwest}

NATIONAL LABORATORY

Proudly Operated by Battelle Since 1965 


\section{DISCLAIMER}

This report was prepared as an account of work sponsored by an agency of the United States Government. Neither the United States Government nor any agency thereof, nor Battelle Memorial Institute, nor any of their employees, makes any warranty, express or implied, or assumes any legal liability or responsibility for the accuracy, completeness, or usefulness of any information, apparatus, product, or process diselosed, or represents that its use would not infringe privately owned rights. Reference herein to any specific commercial product, process, or service by trade name, trademark, manufacturer, or otherwise does not necessarily constitute or imply its endorsement, recommendation, or favoring by the United States Government or any agency thereof, or Battelle Memorial Institute. The views and opinions of authors expressed herein do not necessarily state or reflect those of the United States Government or any agency thereof.

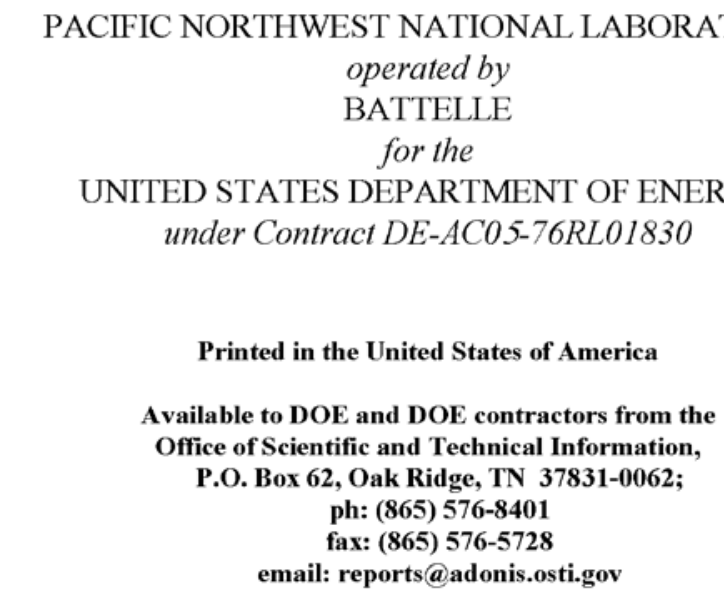

Available to the public from the National Technical Information Service, U.S. Department of Commerce, 5285 Port Royal Rd., Springfield, VA 22161 ph: (800) 553-6847 fax: (703) 605-6900 email: orders@ntis.fedworld.gov online ordering: http://www.ntis.gov/ordering.htm 


\title{
Commissioning an Engineering Scale Coal Gasifier
}

\author{
D Reid \\ JE Cabe
}

MD Bearden

July 2010

Prepared for

the U.S. Department of Energy under Contract DE-AC05-76RL01830

Pacific Northwest National Laboratory

Richland, Washington 99352 



\begin{abstract}
This report explains the development, commissioning, and testing of an engineering scale slagging coal gasifier at PNNL. The initial objective of this project was to commission the gasifier with zero safety incidents. The commissioning work was primarily an empirical study that required an engineering design approach. After bringing the gasifier on-line, tests were conducted to assess the impact of various operating parameters on the synthesis gas (syngas) product composition. The long-term intent of this project is to produce syngas product for use by internal Pacific Northwest National Laboratory (PNNL) researchers in catalyst, materials, and instrumentation development.

Future work on the project will focus on improving the reliability and performance of the gasifier, with a goal of continuous operation for greater than 4 hours using coal feedstock. In addition, alternate designs that allow for increased flexibility regarding the fuel sources that can be used for syngas production is desired. Continued modifications to the fuel feed system will be pursued to address these goals. Alternative feed mechanisms such as a coal/methanol slurry are being considered.
\end{abstract}





\section{Acknowledgments}

The authors gratefully acknowledge the financial assistance of a Laboratory Directed Research and Development (LDRD) project from Pacific Northwest National Laboratory ${ }^{1}$ (PNNL). All research herein was performed at the Integrated Environmental Technologies (InEnTec) facility in Richland, WA.

James Cabe was the project manager and a source of great knowledge and guidance. Stanley L.

Owsley Jr., Mark D. Bearden, Robert J. Robertus, Mike Dodson, and Michael L. Elliott were instrumental in the initial design and construction effort.

\footnotetext{
${ }^{1}$ Proudly Operated for the U.S. Department of Energy (DOE) by Battelle Memorial Institute
} 



\title{
Acronyms and Abbreviations
}

\author{
${ }^{\circ} \mathrm{C}$ \\ ${ }^{\circ} \mathrm{F}$ \\ $\Delta \mathrm{H}^{\mathrm{o}}$ \\ $\tau$ \\ ASTM \\ BTU \\ CGE \\ $\mathrm{CH}_{3} \mathrm{OH}$ \\ DOE \\ InEnTec \\ $\mathrm{k}$ \\ LDRD \\ PEM \\ PLC \\ PNNL \\ PPE \\ psia \\ psig \\ QA \\ Scfm \\ Slpm \\ SNG \\ SOP \\ Syngas \\ TRC \\ WGS \\ Degrees Celsius \\ Degrees Fahrenheit \\ Standard enthalpy change of reaction (units of joules). The enthalpy change that \\ occurs in a system when one mole of reactant is transformed by a chemical \\ reaction at 1 bar and $25^{\circ} \mathrm{C}$. Positive values indicate endothermic reactions, which \\ require a continuous supply of energy from the surroundings to be sustained. \\ Negative values indicate exothermic reactions, which release energy to the \\ surroundings. \\ Residence time (a.k.a. space time, units of seconds); the time necessary to \\ process one reactor volume of reactant based on entrance conditions. The \\ residence time can be thought of as the average time feedstock molecules spend \\ in the gasifier. \\ American Society for Testing and Materials \\ British thermal units \\ Cold gas efficiency \\ Methanol (often abbreviated $\mathrm{MeOH}$ ) \\ U.S. Department of Energy \\ Integrated Environmental Technologies \\ Thermal conductivity in Btu-ft/hr- $\mathrm{ft}^{2}{ }^{\circ} \mathrm{F}$ \\ Laboratory Directed Research and Development \\ Plasma enhanced melter \\ Programmable Logic Controller \\ Pacific Northwest National Laboratory \\ Personal protective equipment \\ Pounds (force) per square inch, absolute \\ Pounds (force) per square inch, gauge \\ Quality Assurance \\ Standard cubic feet per minute \\ Standard liters per minute \\ Substitute natural gas \\ Standard operating procedure \\ Syngas is also known as synthesis gas. It is the name given to a gas mixture that \\ contains varying amounts of carbon monoxide and hydrogen. \\ Thermal residence chamber \\ Water-gas shift
}





\section{Contents}

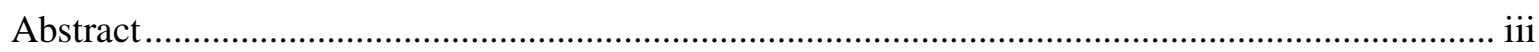

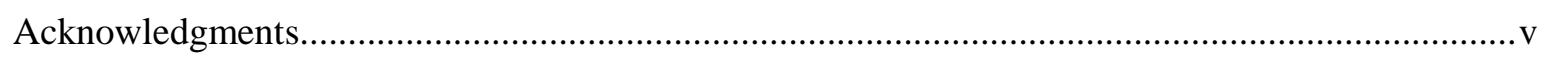

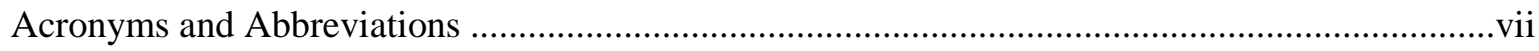

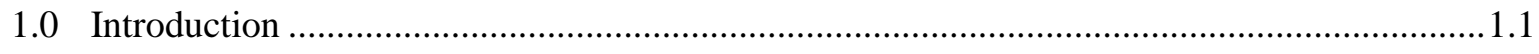

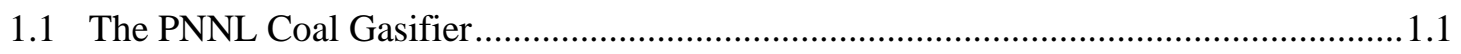

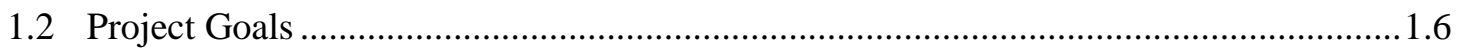

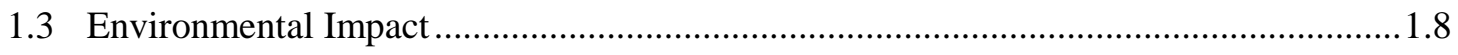

2.0 Design Parameters, Testing, and Results....................................................................... 2.1

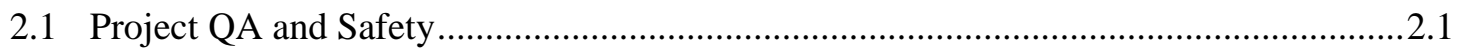

2.2 Engineering Design Approach …........................................................................... 2.1

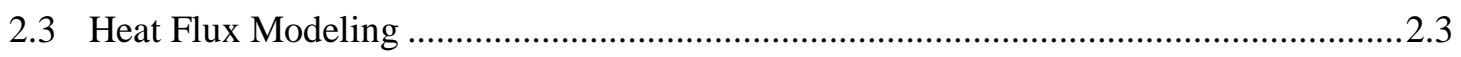

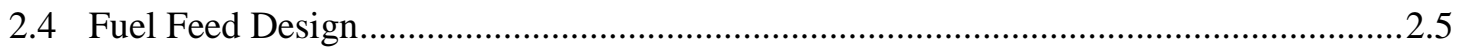

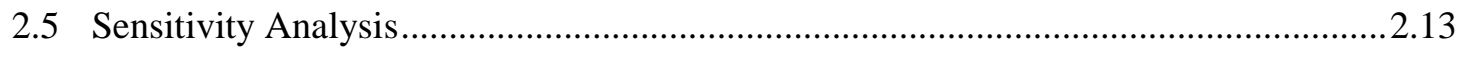

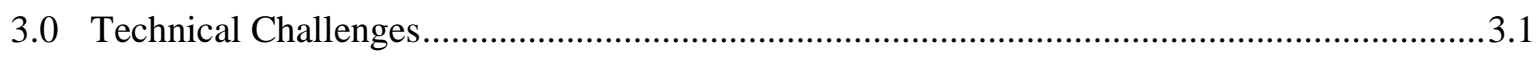

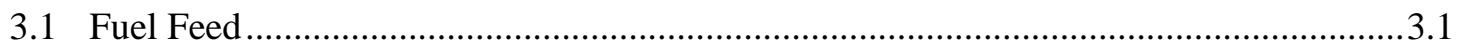

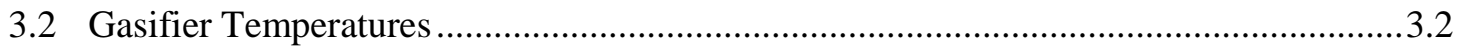

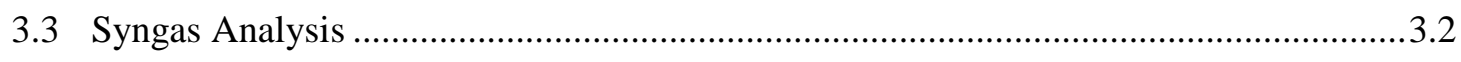

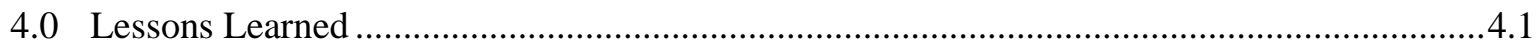

5.0 Conclusions and Recommendations for Future Work....................................................... 5.1

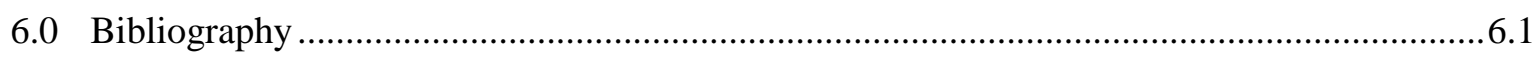

Appendix A Sample System Completion Log Sheet ..................................................................

Appendix B Thermocouple Temperatures with Methanol Fuel .................................................. B.1

Appendix C Thermocouple Temperatures with First Diesel Run.................................................. 1

Appendix D First Successful Coal Run .................................................................................. D. 1

Appendix E Aspen Model Flow Chart...................................................................................... E.1

Appendix F Harbison-Walker Calculations ................................................................................ 1

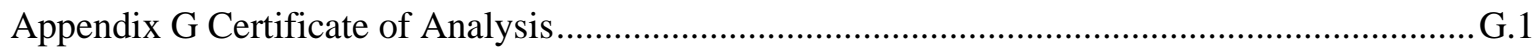

Appendix H Moyno Results....................................................................................................

Appendix I Aurex 70 Castable Data Sheets ............................................................................ I.1

Appendix J KAST-O-LITE Data Sheets..................................................................................... J.1

Appendix K BTU-BLOCK Data Sheets .....................................................................................

Appendix L Oxygen Flow Calibration Curve ............................................................................ L.1

Appendix M Methanol Pump Calibration Curve......................................................................... M.1

Appendix N Coal Auger Calibrated Flow Curve........................................................................1

Appendix O Sensitivity Analysis for Methanol Input Change .................................................. O.1 


\section{Figures}

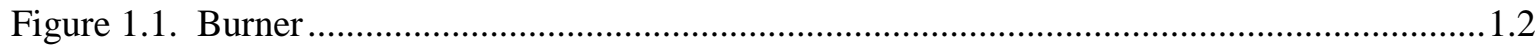

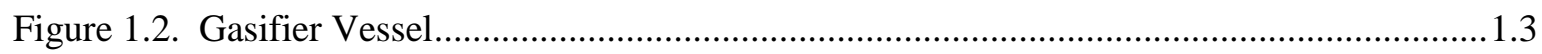

Figure 1.3. PNNL's Engineering Scale Gasifier ..................................................................... 1.5

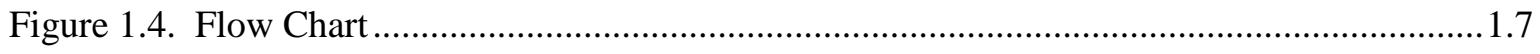

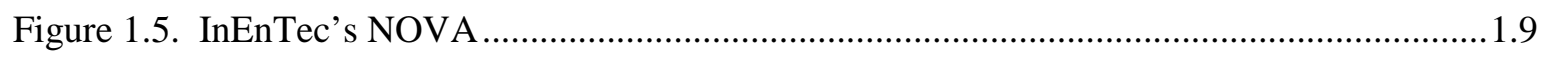

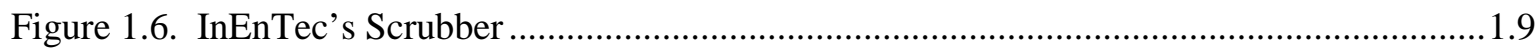

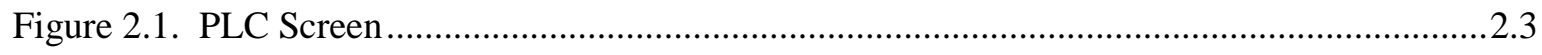

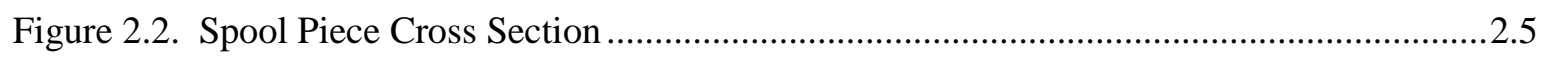

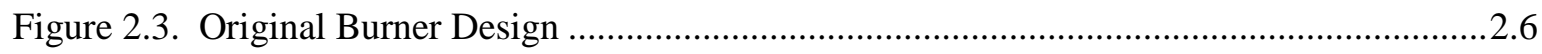

Figure 2.4. Burner Redesign Concept .................................................................................2.7

Figure 2.5. New Burner Three Dimensional Cutaway..............................................................2.7

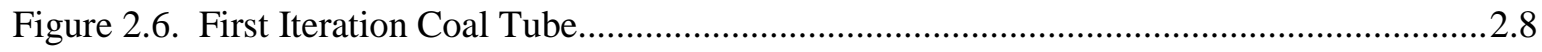

Figure 2.7. Initial Burner Redesign for Dual Fuel Feed ........................................................ 2.9

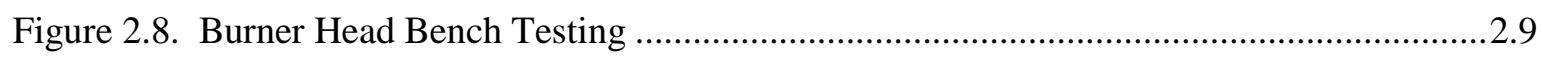

Figure 2.9. Nozzle Spray Testing in Clear Tube........................................................................10

Figure 2.10. Nozzle Spray Pattern Observed ........................................................................ 2.10

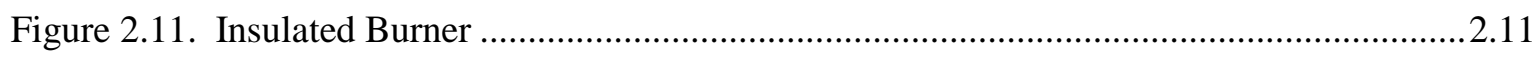

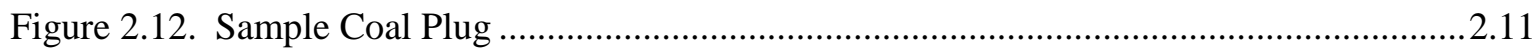

Figure 2.13. Damaged Castable .......................................................................................... 2.12

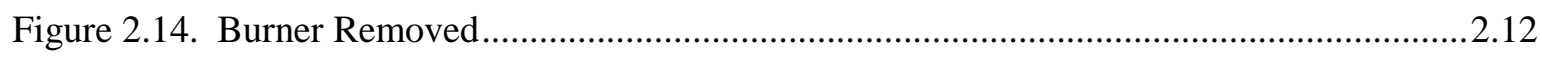

Figure 2.15. Burner Head after Coal Run in February 2010 ...................................................2.13

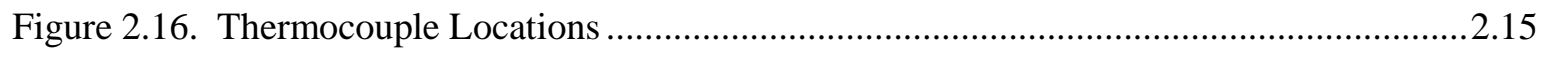

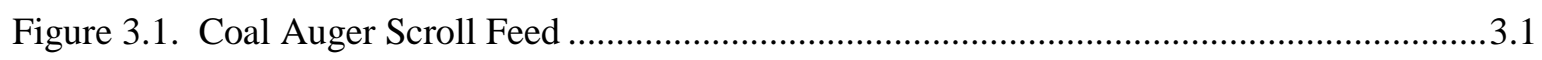

Figure 3.2. Bore Plugged up February 2010 ............................................................................ 3.2

Figure 3.3. Sable Oxygen Analyzer ........................................................................................

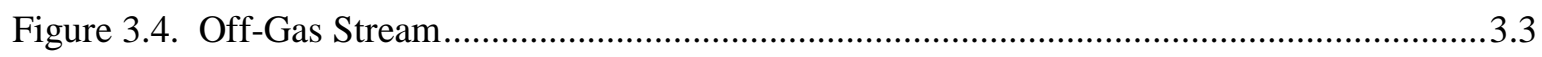

\section{Tables}

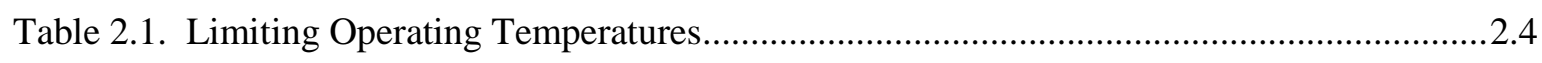

Table 2.2. Fuel Input Conversion Quick Reference.............................................................2.14

Table 2.3. Instrumentation Uncertainty/Parameter Accuracy ..................................................2.14 


\subsection{Introduction}

\subsection{The PNNL Coal Gasifier}

The theory of coal gasification is not described in this document. A separate PNNL issued document addresses these issues [17].

PNNL's gasifier at Integrated Environmental Technologies (InEnTec) is a small entrained flow slagging gasifier of nominally $10 \mathrm{lb} / \mathrm{hr}$ of pulverized coal feed. Oxygen vapor from liquid dewars is used as the oxidant. The primary purposes of this gasifier are to 1) produce an internal slag layer to determine if its thickness could be determined by millimeter wave technology and 2 ) to produce syngas from coal for catalyst and materials testing. Thus the gasifier is not designed for fundamental studies of coal gasification.

The gasification vessel and associated equipment is designed for operation to $250 \mathrm{psig}$. However, limitations of the coal feed system, oxygen supply, syngas processing capability and safety concerns have limited operation to near atmospheric pressure.

In an entrained flow gasifier, finely ground coal feedstock particles undergo thermal decomposition, partial combustion, and reaction with steam and other gas components as they are dragged along with the self generated gas stream in co-current flow.

Dry, pulverized solid coal is fed from a small nitrogen purged screw feeder and a liquid fuel (methanol) are fed to a burner located at the top of the gasifier vessel by a hopper system with nitrogen push gas and a pump, respectively (see Figure 1.1). The burner serves to establish good mixing between the fuel(s) and the oxygen, so that the gasification reactions take place in a dense cloud of very fine particles. (Methanol provides a reliable feed source that serves to attenuate temperature fluctuation in the gasifier caused by variability of the instantaneous coal feed rate from the hopper system.) 


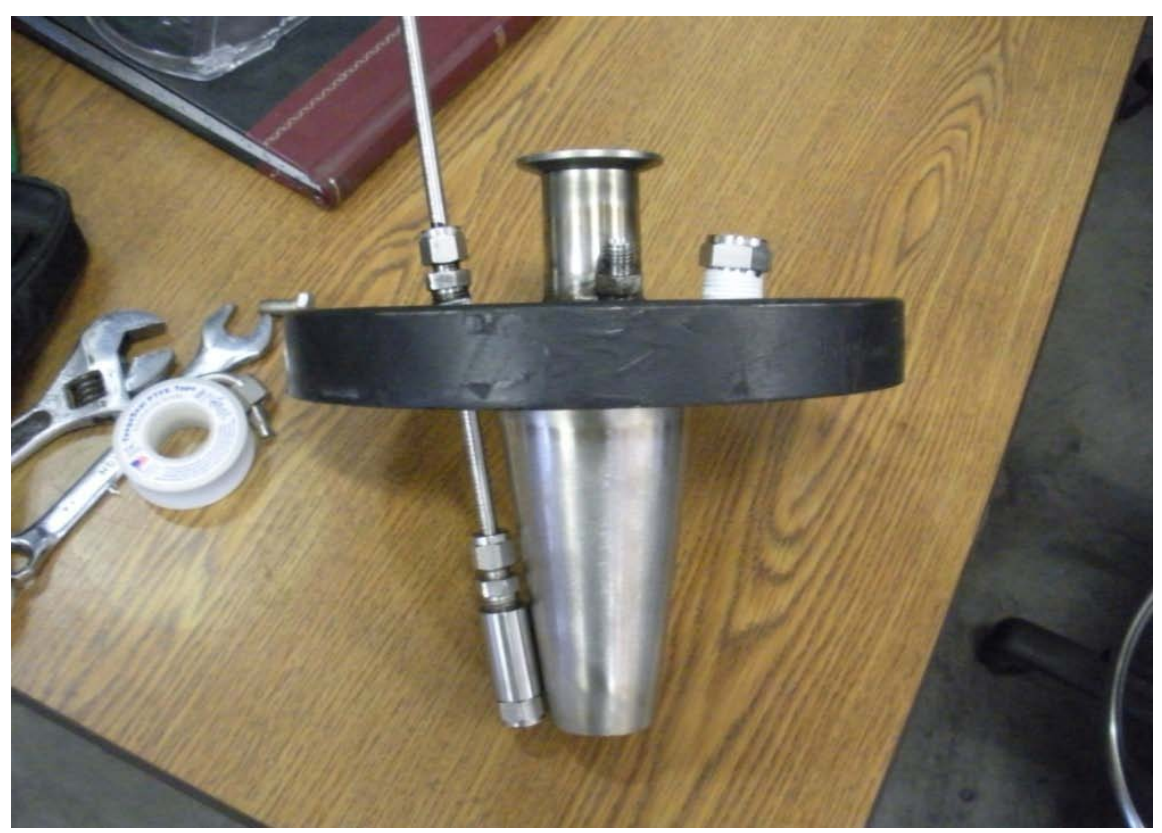

Figure 1.1. Burner

Below the burner, the gasifier vessel 3, 16" pipe flanged spool pieces bolted together to form a vessel approximately 9' tall (see Figure 1.2). The first two segments of the gasifier are lined with concentric layers of ceramic fiber blanket insulation, castable insulating refractory, and an interior dense castable ring, leaving an internal, empty cylindrical chamber in the center. The insulation and refractory layers protect the gasifier walls from high temperature and prevent excessive heat loss. The cylindrical chamber is designed to provide residence time for the coal to gasify and gas reactants to approach equilibrium at $250 \mathrm{psig}$ and $2,500^{\circ} \mathrm{F}$. 


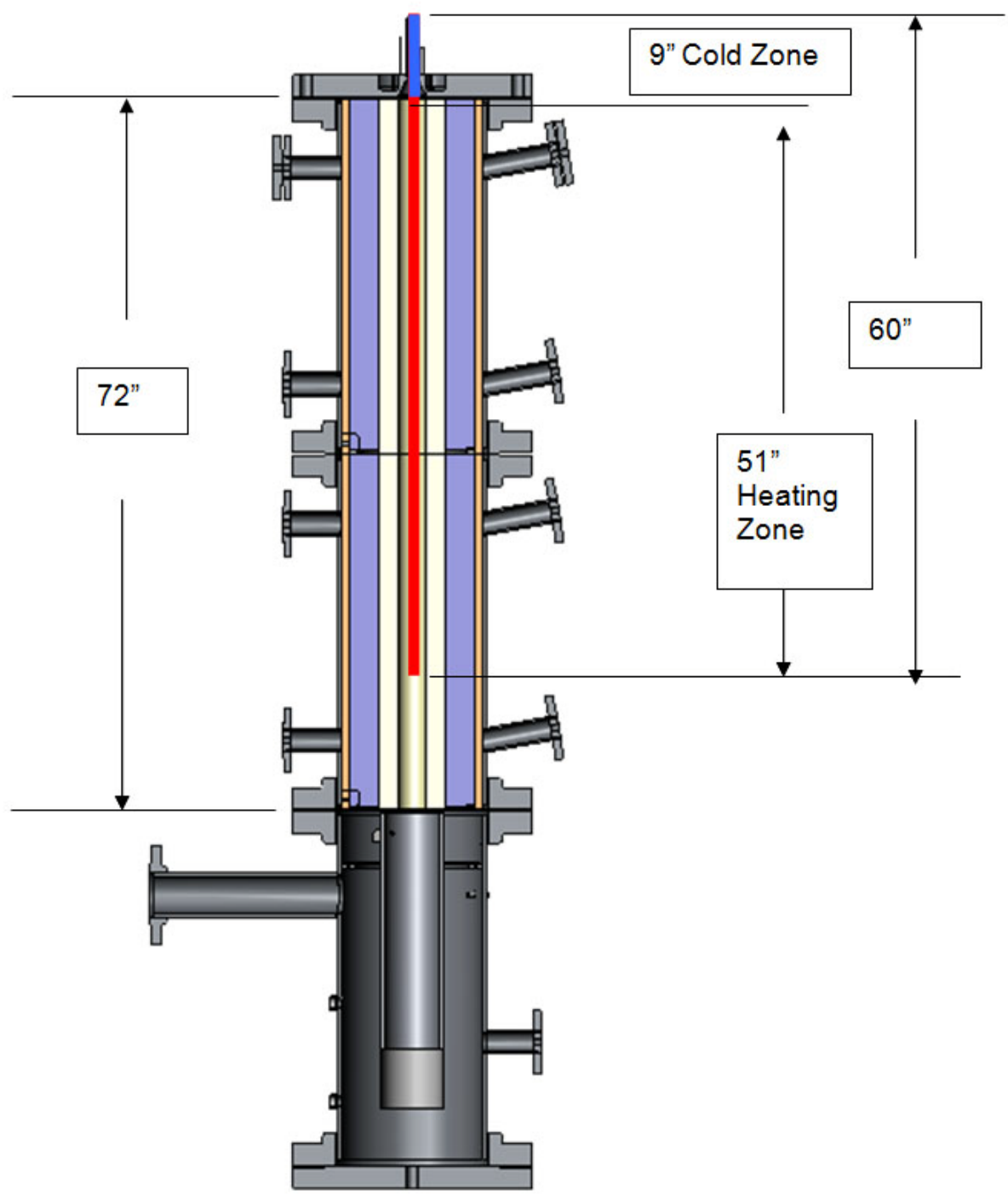

Figure 1.2. Gasifier Vessel

The gasifier is designed to react the coal feed at $2,500^{\circ} \mathrm{F}$ which is above the melting point of the coal ash. The molten ash, composed primarily of silica and alumina minerals (slag) form a highly viscous layer on the inner wall of the gasifier, with liquid slag being solidified and then removed at the bottom of the gasifier. The ash fluid temperature estimated for the Pocahontas coal used in the PNNL gasifier is $2,201^{\circ} \mathrm{F}$ [6]. The Pocahontas coal used is a low sulfur seam coal from West Virginia. The coal was ground extremely fine for greater reactivity and conversion. For a certificate of analysis of the coal fed to the PNNL gasifier refer to Appendix A.

In the third section, water is sprayed through nozzles into the gas stream to rapidly lower its temperature and stop reaction. 


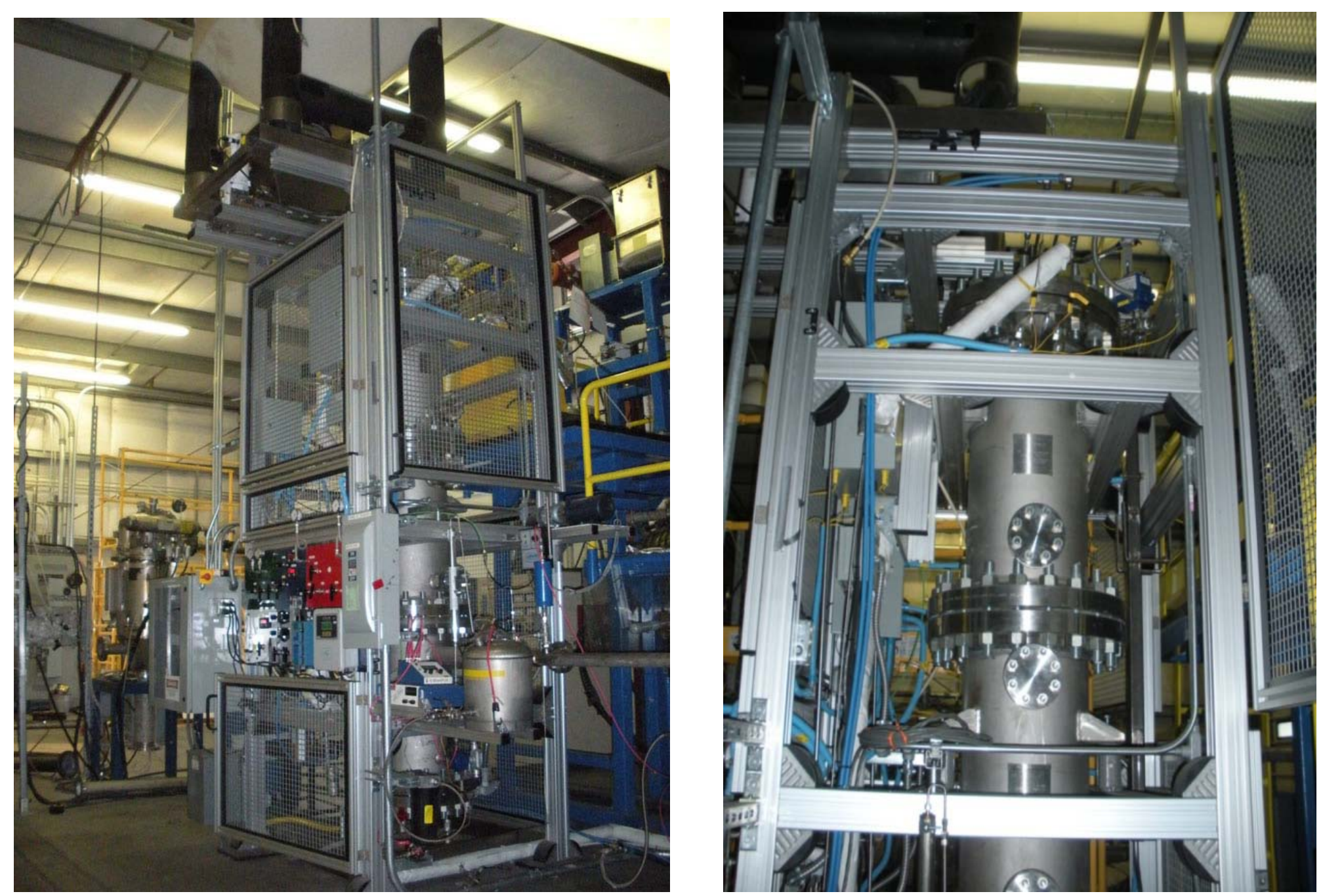

Figure 1.3. PNNL's Engineering Scale Gasifier 


\subsection{Project Goals}

The primary goals of this gasification project were to safely commission the gasifier and to provide internal PNNL customers with syngas. This project was not funded to significantly advance the science of commercial gasification, but rather to serve as a research and development effort aimed at enhancing PNNL's internal capabilities with respect to operating a small-scale gasifier. Success was defined by completion of the following milestones:

- Develop and maintain a standard operating procedure (SOP) [18] and safe operating practices

- Start up the gasifier on methanol $\left(\mathrm{CH}_{3} \mathrm{OH}\right)$

- Transition to a higher energy density fuel (diesel)

- Transition to coal feed

- Develop sustainable run procedures and capability

- Align future efforts with research objectives/projects at PNNL

- Produce syngas for internal PNNL customers.

The technical goals of this project include maximizing the conversion of carbon from the solid to gas phase, running the gasifier continuously for a length of four hours or more, and being able to fine-tune the inputs/operating conditions of the gasifier to achieve a desired syngas composition. Figure 1.4 is the process flow chart showing the inputs and outputs of the gasifier. 


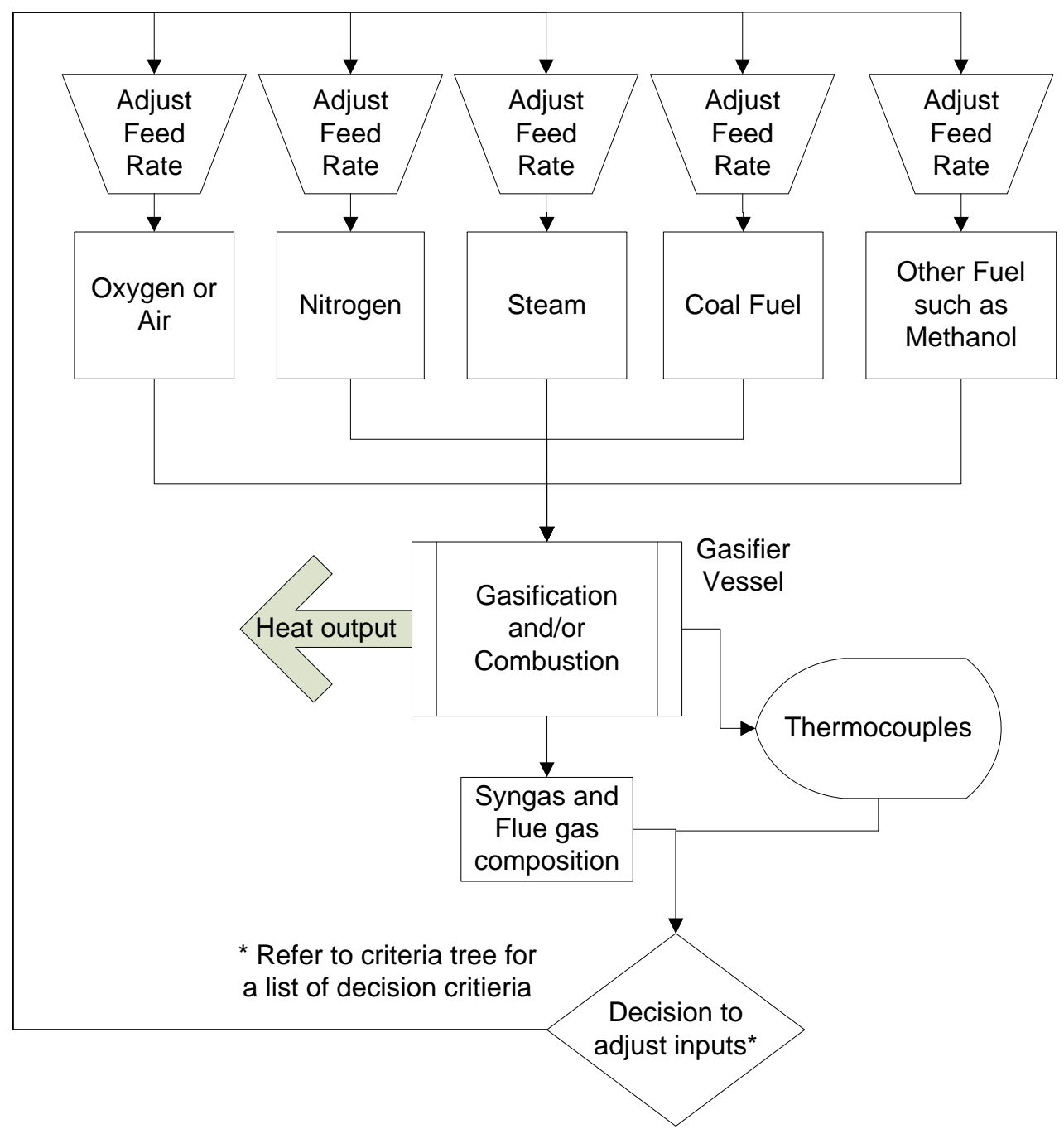

Figure 1.4. Flow Chart

The following conditions are monitored during gasifier operation:

1. Gasifier Internal Temperature. If the temperature read by any thermocouple exceeds $1,425^{\circ} \mathrm{C}$ $\left(2,600^{\circ} \mathrm{F}\right)$ an alarm is set off. A temperature exceeding $1,510^{\circ} \mathrm{C}\left(2,750^{\circ} \mathrm{F}\right)$ initiates the emergency stop system (ESTOP), which instantaneously stops fuel and oxygen from entering the gasifier.

2. Syngas Oxygen $\left(\mathrm{O}_{2}\right)$ Content. If the continuous oxygen meter registers more than $1.0 \% \mathrm{O}_{2}$ in the exiting syngas outlet stream for a period of time that exceeds the expected lag time between syngas sample and measurement, ESTOP is initiated. (Normal syngas $\mathrm{O}_{2}$ content is from 0.1 to $0.3 \%$ ).

3. Syngas Hydrogen $\left(\mathrm{H}_{2}\right)$ Content. Altered by adjusting fuel and oxygen inputs.

4. Syngas $\mathrm{CO}$ to $\left(\mathrm{CO}+\mathrm{CO}_{2}\right)$ Ratio. Altered by adjusting fuel and oxygen inputs.

5. Syngas $\mathrm{CO}$ to $\mathrm{H}_{2}$ Ratio. Altered by adjusting fuel and oxygen inputs.

6. Gasifier Heat Ramp. The rate the gasifier bore heats up should not to exceed $150^{\circ} \mathrm{C} / \mathrm{hr}$. 
7. Gasifier Pressure and Delta Pressure. ESTOP is initiated if pressure in the gasifier exceeds 5 psig. Normal gasifier operation requires the pressure to be below the high-high set point of 2 psig. The gasifier's delta pressure (inlet to outlet) is not to exceed 1.5 psig. (A 1 psig pressure is maintained at the coal fuel hopper.)

8. Fuel to $\mathrm{O}_{2}$ Ratio. Sub-stoichiometric for gasification.

9. For additional conditions, refer to the alarm response section of the SOP[18].

PNNL leases space at Integrated Environmental Technologies (InEnTec). Figure 1.2 shows the gasifier located in the InEnTec facility in Richland, WA. Facility information can be found on the InEnTec website [10].

\subsection{Environmental Impact}

Before constructing a gasifier facility, PNNL considered the environmental impact. The syngas product stream from the PNNL gasifier is sent through existing equipment maintained by InEnTec for treatment of syngas produced by their plasma enhanced melter (PEM) waste-to-energy technology. The analytics was performed by InEntec's NOVA instrument (figure 1.5). The syngas is quenched with water at the bottom of the gasifier vessel. InEnTec disposes of the quench water via approved regulatory disposal paths. Next, the syngas passes through a thermal residence chamber (TRC), which is a refractory-lined empty steel vessel. The TRC provides additional cooling for the syngas. The syngas exits the TRC and moves into a packed column scrubber (figure 1.6), which removes acid gases $\left(\mathrm{CO}_{2}\right.$ and $\mathrm{H}_{2} \mathrm{~S}$ ) and particulates. After passing through the scrubber, the gas is directed through a high efficiency particulate air (HEPA) filter. The cleaned syngas is then released to the atmosphere through a stack. 


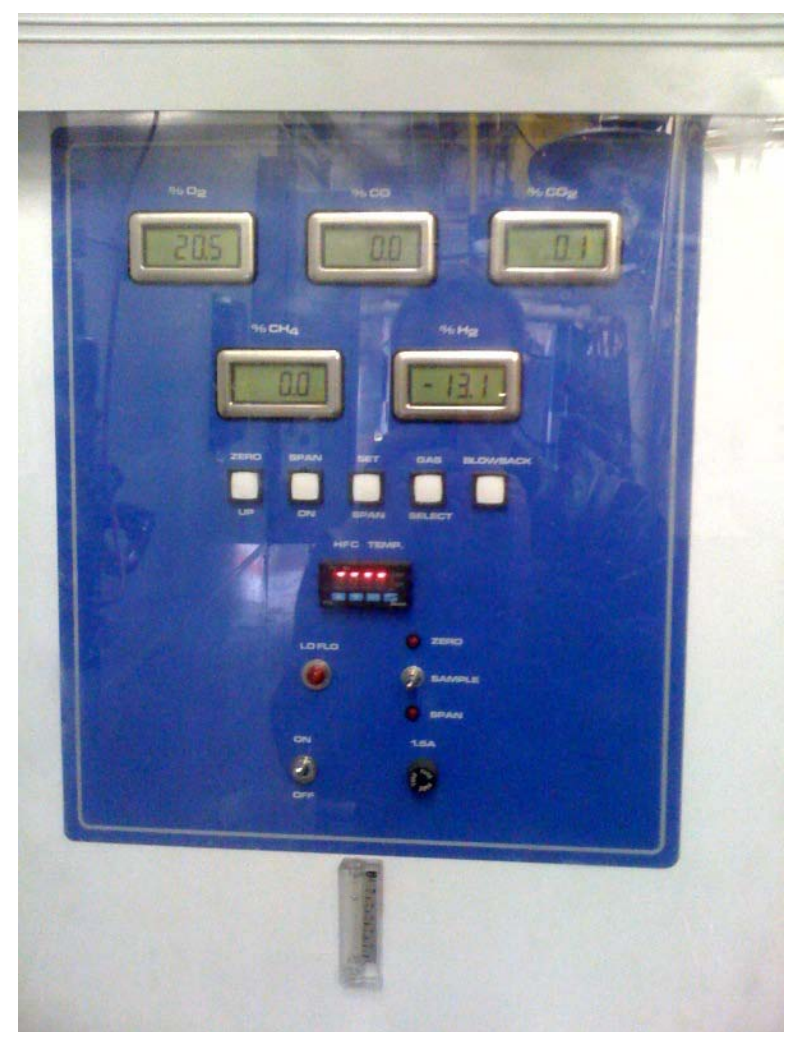

Figure 1.5. InEnTec's NOVA

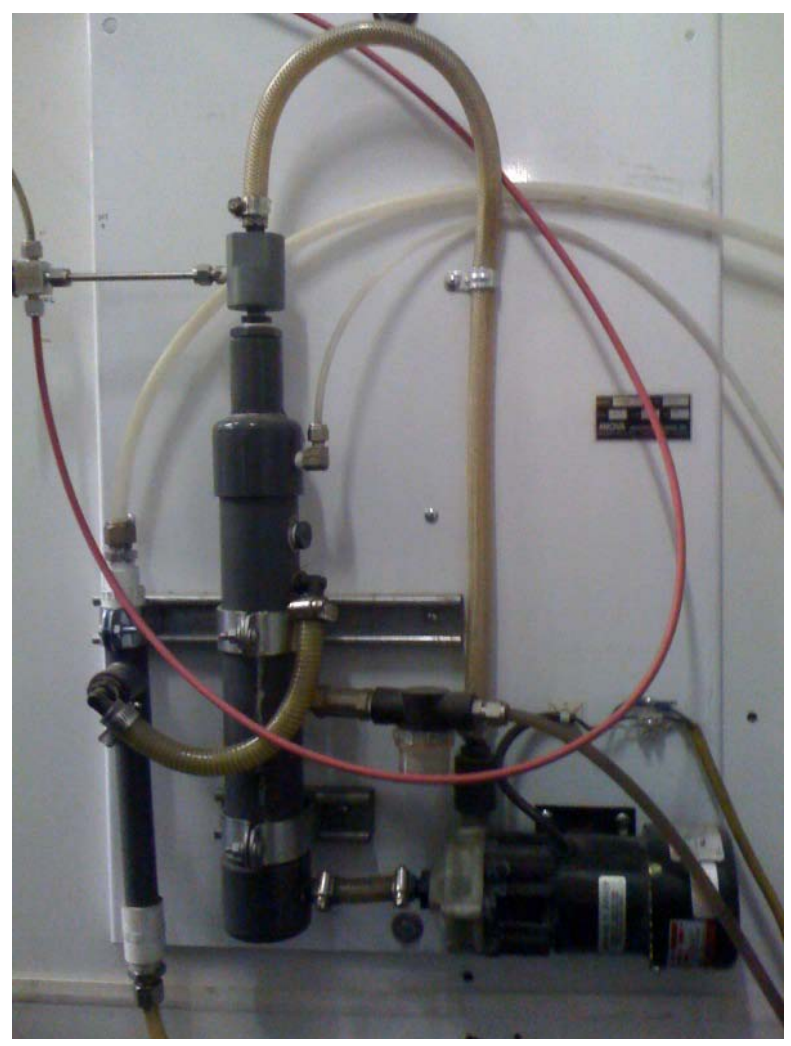

Figure 1.6. InEnTec's Scrubber 



\subsection{Design Parameters, Testing, and Results}

An entrained flow slagging gasifier was developed, commissioned, and tested. This chapter addresses the system design, the engineering design approach, testing, and results.

\subsection{Project QA and Safety}

A standard quality assurance process was implemented and followed during the gasifier commissioning. First, a hazard assessment was conducted to assess physical and chemical hazards to which lab employees may be exposed. Based on the hazard assessment the required personal protective equipment (PPE) was determined and a standard operating procedure was developed, maintained, and followed. Appropriate PPE includes such items as safety goggles, Nomex or Tyvek suits, appropriate gloves, and dust masks when working with the pulverized coal.

Implementation of system changes were documented on system logs; a sample system log is provided in Appendix A. When non-conformance issues were discovered, immediate corrective action was taken to mitigate potential hazards. Lessons learned were documented and discussed with the project team to prevent future occurrences. An example of this was the observance of audible deflagrations during one of the runs. This led to the design of alternative feed systems including a slurry feed system discussed in Chapter 5.

\subsection{Engineering Design Approach}

An engineering design approach was applied to commissioning the gasifier. This approach focused on the coordination of all the individual tasks, activities, and technical disciplines to develop a total system. This methodology involves the understanding of the problem statement, identification of objectives and requirements, concept selection, system creation, system operation, and life cycle management.

Before any experimentation could be performed, the incomplete engineering scale coal gasifier required system completion. To achieve mechanical and electrical system completion, the project team created and completed system check-out and mechanical logs. These logs helped track the process of equipment modification, addition, elimination, and testing. The team followed engineering best practices including peer review and quality assurance measures. When appropriate, certain subsystems were independently developed and bench tested prior to connecting them together in a cohesive system. This approach allowed parallel development and thorough pre-testing of each subsystem as well as simultaneous procurement of parts. All components were organized into a system/subsystem list as follows:

- Purge system

- Gas supply (provided by InEnTec facility)

- Nitrogen to head

- Nitrogen to coal hopper

- Manual stop valve 
- Oxygen system

- Gas supply (provided by InEnTec facility)

- Manual stop valve

- Inlet/outlet pressure

- Dwyer meter

- Block valve

- Injection tubing and/or nozzles

- Water systems

- Cold water supply to head

- Filter for head water

- Flow valve

- Cold water supply to basin

- Filter for basin water

- Spray nozzles for basin

- Structure/Frame

- Cages

- Safety structure

- Gasifier

- Steel vessel

- Flanges and sealing surfaces

- Refractories and BTU-BLOCK

- Bolting

- Insulation

- Feed systems

- Containers

- Filters

- Drawdown tube

- Pumps

- Valving (isolation and check)

- Nozzles

- Instrumentation (run via programmable logic controller (PLC) see Figure 2.1)

- Steam, oxygen, and coal block valves 
- Slag basin fill and discharge valves

- Oxygen flow control valve

- Off-gas analyzers including the NOVA (gas analyzer at InEnTec http://www.novaanalytic.com/brand.html )

- Emergency-stop

- Water basin level switches

- Thermocouples

- Pressure sensors

- Fuel feed control

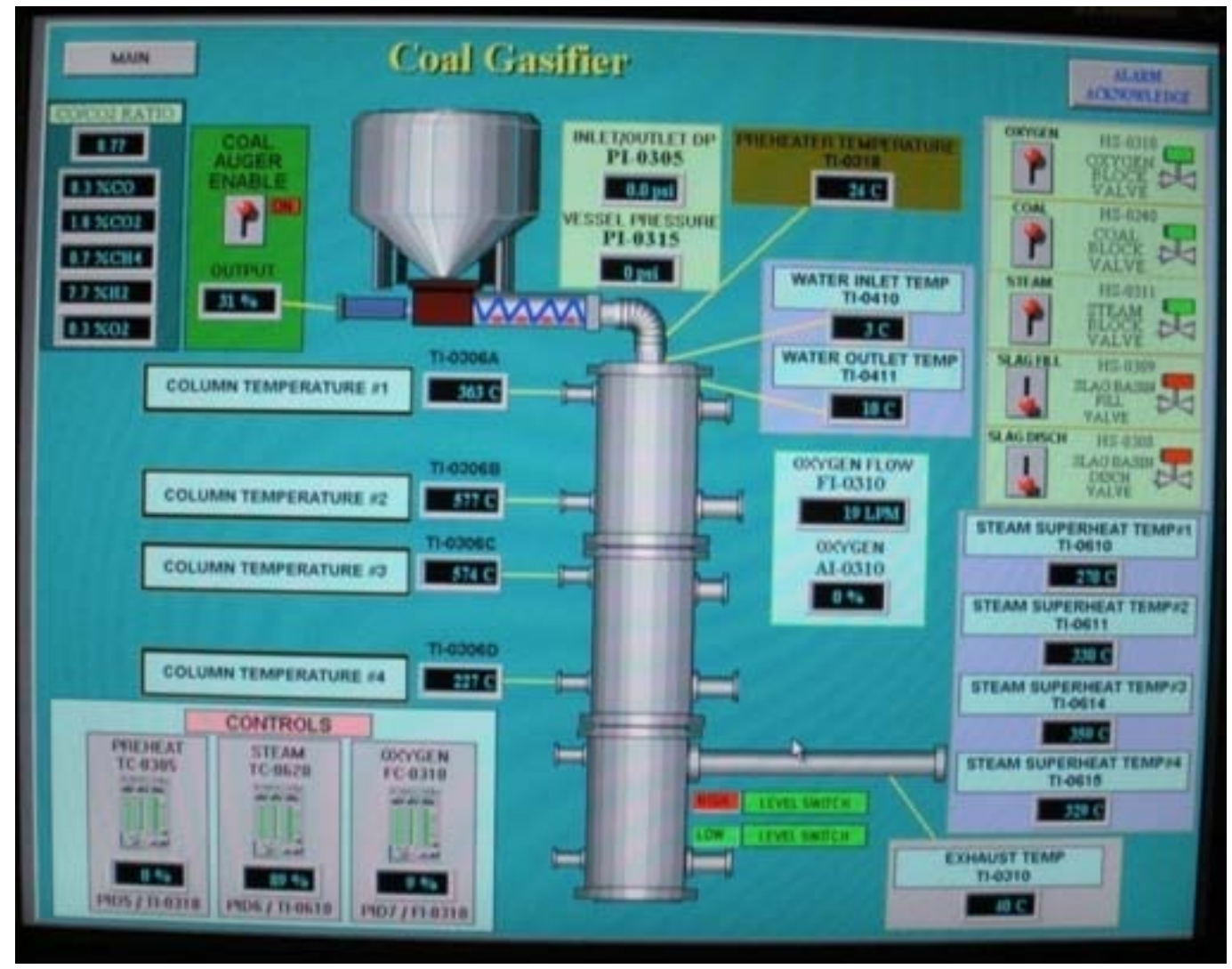

Figure 2.1. PLC Screen

\subsection{Heat Flux Modeling}

Thermal modeling of the gasifier vessel takes into account the various thermal conductivity values (K), various heat transfer rates (units of Btu/hr), heat transfer rates per unit area (units of Btu/hr- $\mathrm{ft}^{2}$ ), and internal heat generation as calculated by the AspenPlus ${ }^{\circledR}{ }^{1}$ program. AspenPlus is one of the many software tools that are used to simulate the material and energy balances for the chemical process

\footnotetext{
${ }^{1}$ AspenPlus is a registered trademark of AspenTech Incorporated.
} 
industry. Dr. Robertus of PNNL was instrumental in the initial calculations. Acceptable operating temperatures are material specific and are provided in data sheets from the vendors. Table 2.1 lists the materials of construction along with their limiting operating temperatures.

Table 2.1. Limiting Operating Temperatures

\begin{tabular}{cc}
\hline Material & Maximum Recommended Service Temperature \\
\hline Aurex 70 & $1,816^{\circ} \mathrm{C} / 3,300^{\circ} \mathrm{F}$ \\
Kast-O-Lite 50-25 & $1,371^{\circ} \mathrm{C} / 2,500^{\circ} \mathrm{F}$ \\
BTU-block & $649^{\circ} \mathrm{C} / 1,200^{\circ} \mathrm{F}$ \\
\hline
\end{tabular}

In the original gasifier, KS-4V-Plus (http://www.empire-refractory.com/catalog/ks-4v-plus.htm) was installed; however, after flame impingement damaged the liner, it was replaced with Aurex 70 . Aurex 70 has a higher heat tolerance.

The operating pressures are driven by the internal reactions and are observed by pressure sensors. To calculate the internal heat generation, Aspen modeling was performed by senior PNNL staff using AspenPlus version 2006.5. The Aspen combustion databank was used for these heat load predictions and a flow chart is displayed in Appendix F. The modeling approach assumes RGIBBS equilibrium reactors were used, which minimize Gibbs free energy (i.e., stoichiometric equations are not required and equilibrium is determined from the free energy). Additional simplifying assumptions include an atmospheric operating pressure at sea level (14.696 psia), a constant feed temperature of $15.5^{\circ} \mathrm{C}\left(60^{\circ} \mathrm{F}\right)$, and that ionization can occur in combustion flames or gases at high temperature. Resulting flame temperatures were calculated to be $2,628^{\circ} \mathrm{C}\left(4,762^{\circ} \mathrm{F}\right)$ without ionization and $2,479^{\circ} \mathrm{C}\left(4,494^{\circ} \mathrm{F}\right)$ with ionization. In the case of ionization, the resulting flame burns at such a temperature as to strip electrons from many compounds, producing positively charged ions and electrons and reducing the energy available to increase the temperature. The energy from this reaction center is radiated away in all directions with the most lost to the quench section where water spray reduces the temperature to near ambient. Additional energy radiates to the refractory walls where it is conducted through the refractory and vessel wall layers and ultimately to the ambient air surrounding the gasifier shell.

The Harbison-Walker website [8] provides a heat flux modeling capability. This website employs the American Society for Testing and Materials (ASTM) C680-08 [1] standards of practice to provide the algorithms and calculation methodologies for predicting the heat loss or gain and surface temperatures of certain thermal insulation systems that can attain one-dimensional, steady- or quasi-steady-state heat transfer conditions in field operations. This practice is based on the assumption that the thermal insulation systems can be well defined in rectangular, cylindrical or spherical coordinate systems and that the insulation systems are composed of homogeneous, uniformly dimensioned materials that reduce heat flow between two different temperature conditions. ASTM C680-08 also specifies that qualified personnel familiar with insulation-systems design and analysis should resolve the applicability of the methodologies to real systems. The range and quality of the physical and thermal property data of the materials comprising the thermal insulation system limit the calculation accuracy. PNNL consulted the Harbison-Walker website to determine predicted temperatures of each layer of the gasifier under various conditions. The website tool includes material properties for the materials of construction used in PNNL's engineering scale gasifier. The Harbison-Walker website tool also allowed PNNL staff to create scenarios where various thicknesses of the spool piece walls could be varied thus resulting in different 
thermal profiles. The hypothetical thermal profiles allowed staff to determine minimum thicknesses of the individual constituents that are necessary to maintain safe operating temperatures. Figure 2.2 shows the refractory layout in a cross section of a typical spool piece (note: dimensions shown have changed in the latest modified design).

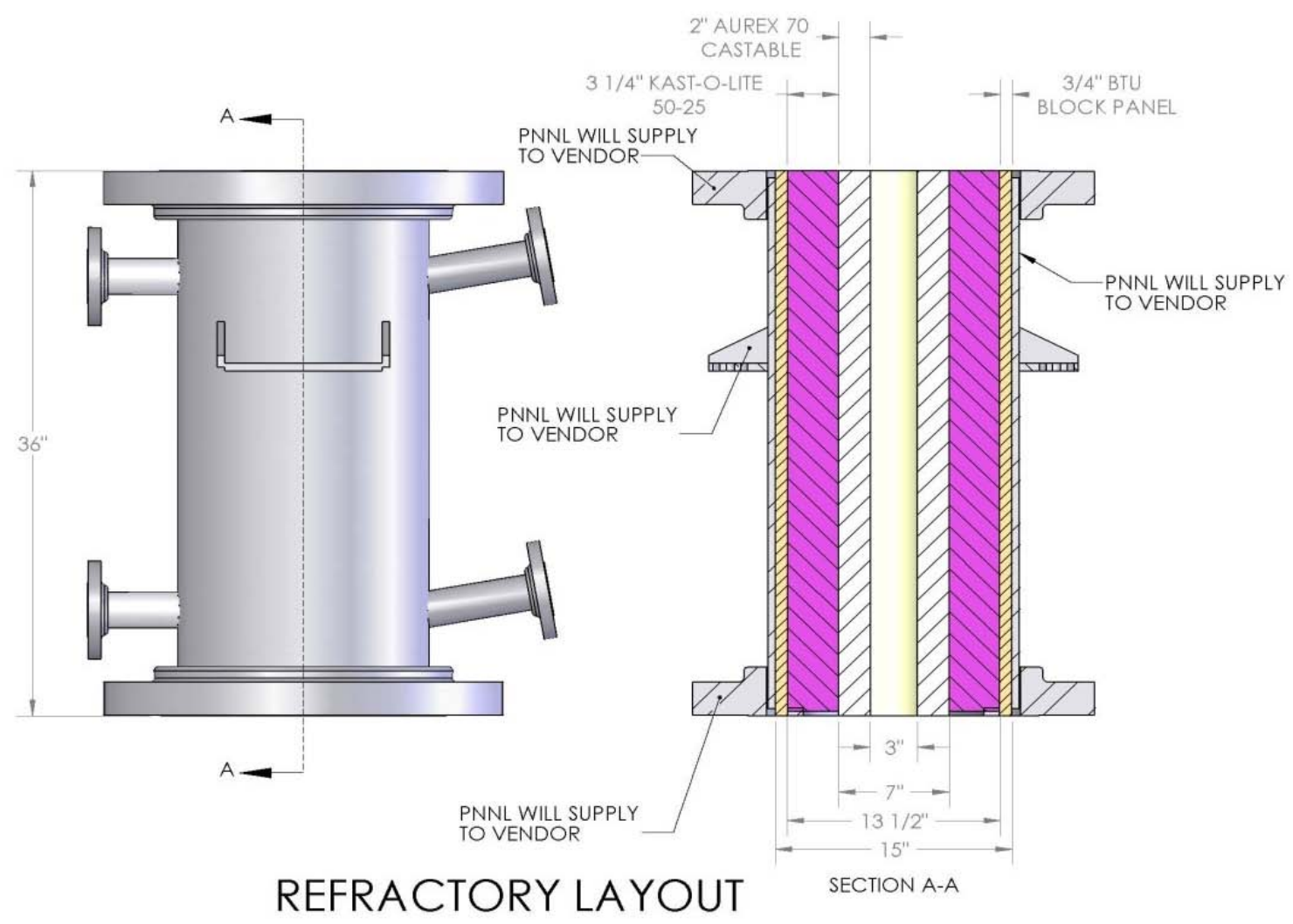

Figure 2.2. Spool Piece Cross Section

\subsection{Fuel Feed Design}

Many feed designs were considered to deliver both the coal and the methanol and many driving parameters were considered in the head design. Such parameters included the dynamics of mixing feed constituents. Feed dynamics involve velocities, residence time, chemical reactions, and the target percent of carbon conversion. Residence time (also known as space time, denoted by the symbol $\tau$ is the time necessary to process one reactor volume of reactant based on entrance conditions. In the case of a gasifier, the residence time can be thought of as the average time feedstock molecules spend in the gasifier. Residence time is related to the volume $(\mathrm{V})$ and the volumetric flow rate $(V)$ in the mathematical relation:

$$
\tau=\frac{V}{v}
$$

Previous modeling based on a vessel pressurized at 150 psig predicted a 2 second residence time. Experimentation at near atmospheric conditions suggests a residence time of less than a half second. The 
feed design will largely affect the residence time as well as the internal heat production and distribution. Modeling suggests certain temperatures or distributions, but experimental data ultimately recalibrated the understanding of how the system behaves.

The original burner design is shown in Figure 2.3. This design included integral water cooling system that was experimentally determined unnecessary in future iterations. The original design did not facilitate easy access to the bore and did not allow a dual fuel feed capability.

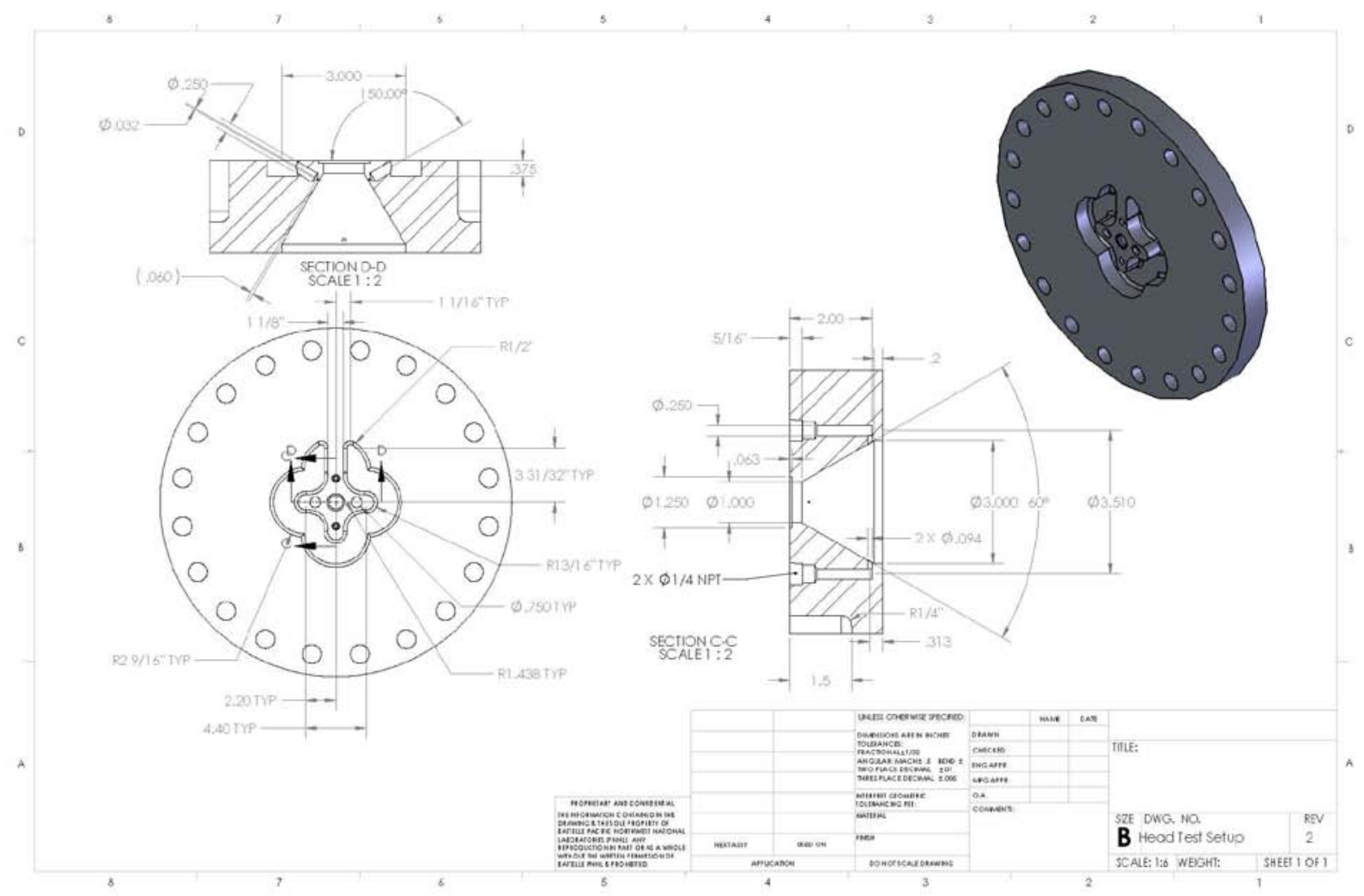

Figure 2.3. Original Burner Design

Figure 2.4 shows a rendered solid model of the first redesign of the feed head. This initial change allowed for easy access to the bore. 


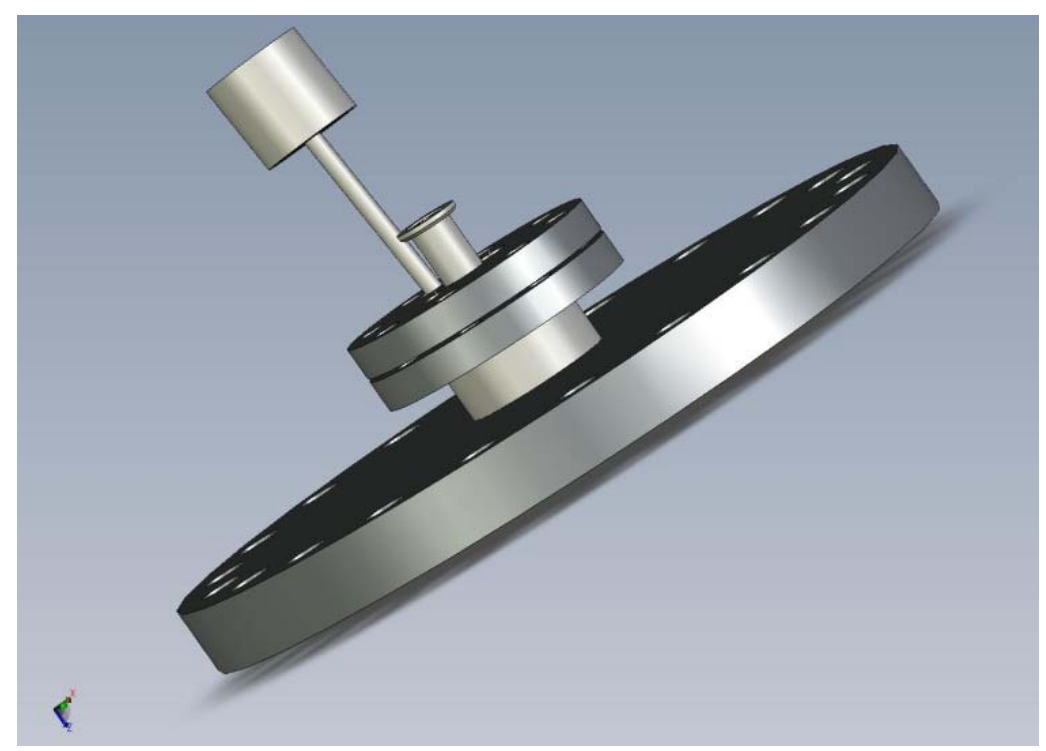

Figure 2.4. Burner Redesign Concept

Figure 2.5 is a cut away view of the redesigned burner head. The oxygen, nitrogen, and steam were injected into the annular space between the inner coal feed tube and the reducer.

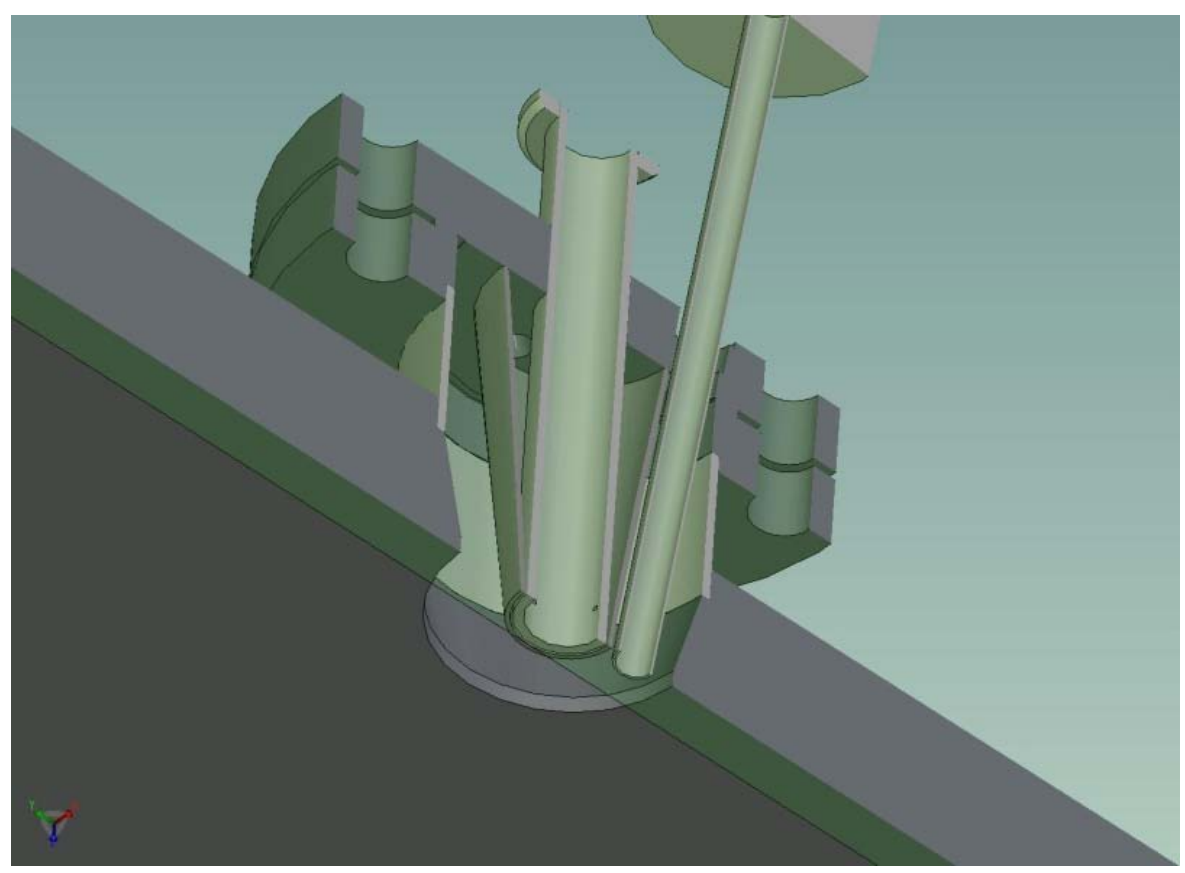

Figure 2.5. New Burner Three Dimensional Cutaway

Figure 2.6 shows the first iteration of the coal tube. After several trial runs, steam was eliminated from the feed process. It was difficult to keep the steam in the vapor phase and was determined that the attenuating quality of steam addition was not necessary to control the reactions.

The initial process of heating up the gasifier bore involves inserting an electric heating rod and gradually heating the bore over a 24-hour period. Once the top two thermocouples in the bore exceed 
$600^{\circ} \mathrm{C}\left(1,112^{\circ} \mathrm{F}\right)$, the heating rod is removed. Methanol is then injected at a controlled rate until the temperature of the first two thermocouples exceeds $1,000^{\circ} \mathrm{C}\left(1,832^{\circ} \mathrm{F}\right)$. At this point, varying rates of coal and methanol are fed into the gasifier.

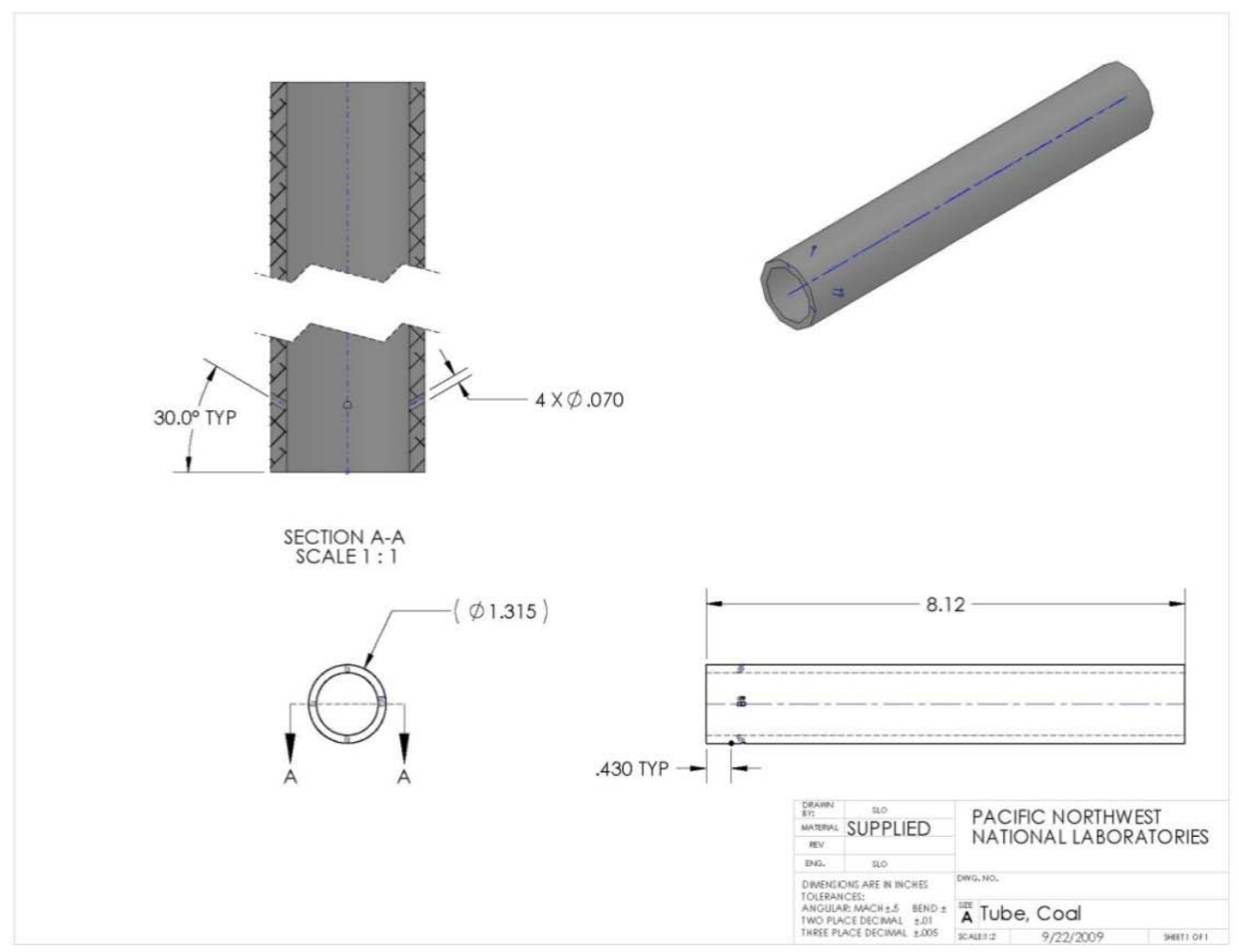

Figure 2.6. First Iteration Coal Tube

Figure 2.7 shows the installation of the methanol fuel post. The first run involving coal feed resulted in a plug in the coal feed tube. Figure 2.12 shows one of the coal plugs. More nitrogen was added in an attempt to apply motive energy.

Prior to running the new head design, a series of bench top tests (Figure 2.8) were performed to simulate the coal feed with the forced jet mixing provided by the four holes shown in Figure 2.6. Effective mixing was observed using a silica sand substitute for coal; however the mixture tended to form eddies. This indicated that some of the coal was being drawn back up toward the outside of the reducer thereby increasing the surrounding feed head temperature. Based on bench testing of the fuel spray (Figure 2.9 and Figure 2.10), gas injection, and coal feed, the burner was insulated to protect it from extreme temperatures. Insulation was wrapped around the burner, as shown in Figure 2.11, but coal still plugged the opening as a result of the processes of coal devolatilization, softening, and swelling within the burner head. A 1-lb check valve was added to the coal hopper using nitrogen to prevent backpressure and syngas leaks. Coal plugging was still encountered. When the nitrogen feed rate was increased another problem was encountered. If the worst case flame temperature of $2,628^{\circ} \mathrm{C}\left(4,762^{\circ} \mathrm{F}\right)$ was actually reached and the oxygen force from the 0.07-inch diameter nozzles forced the flame front to the extreme sides of the bore, the maximum service temperature of $1,371^{\circ} \mathrm{C}\left(2,500^{\circ} \mathrm{F}\right)$ would clearly have been 
exceeded leading to the damage to the castable shown in Figure 2.13 and Figure 2.14. It is also believed that at least two of the nozzle holes were plugged thereby doubling the nozzle velocity of the remaining two holes.

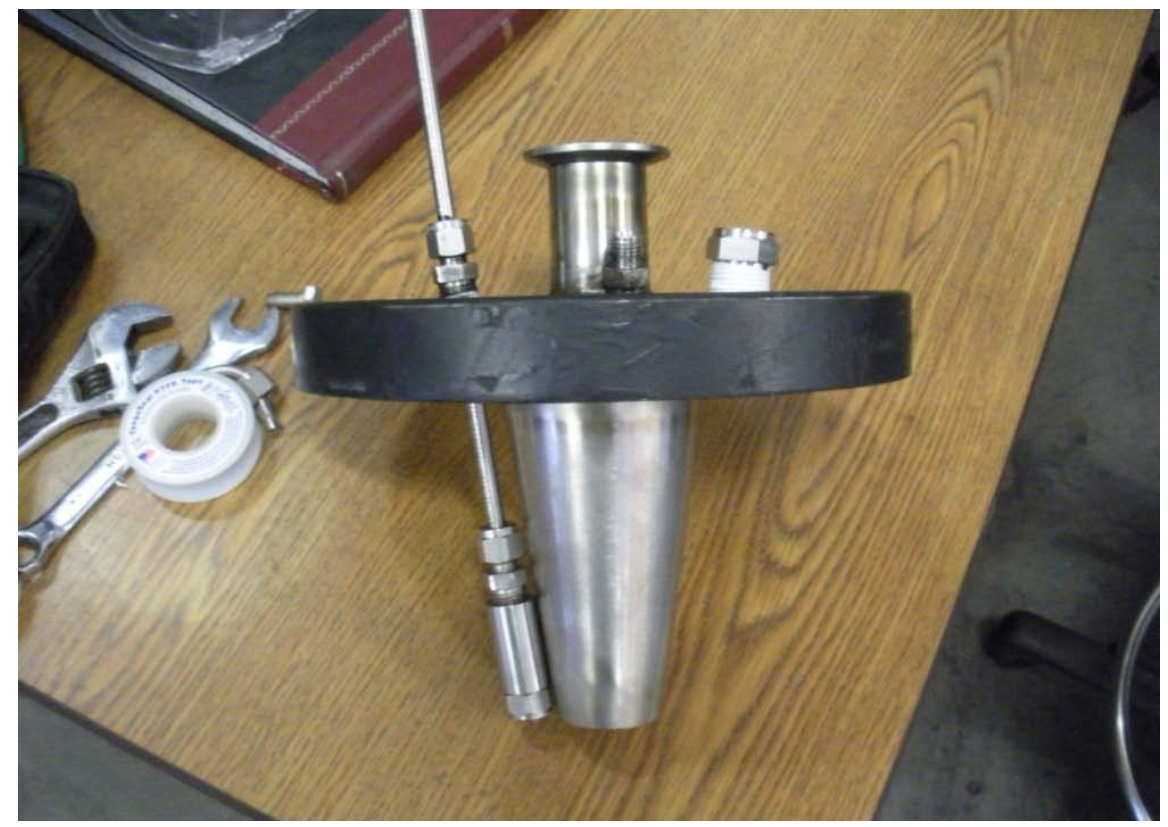

Figure 2.7. Initial Burner Redesign for Dual Fuel Feed

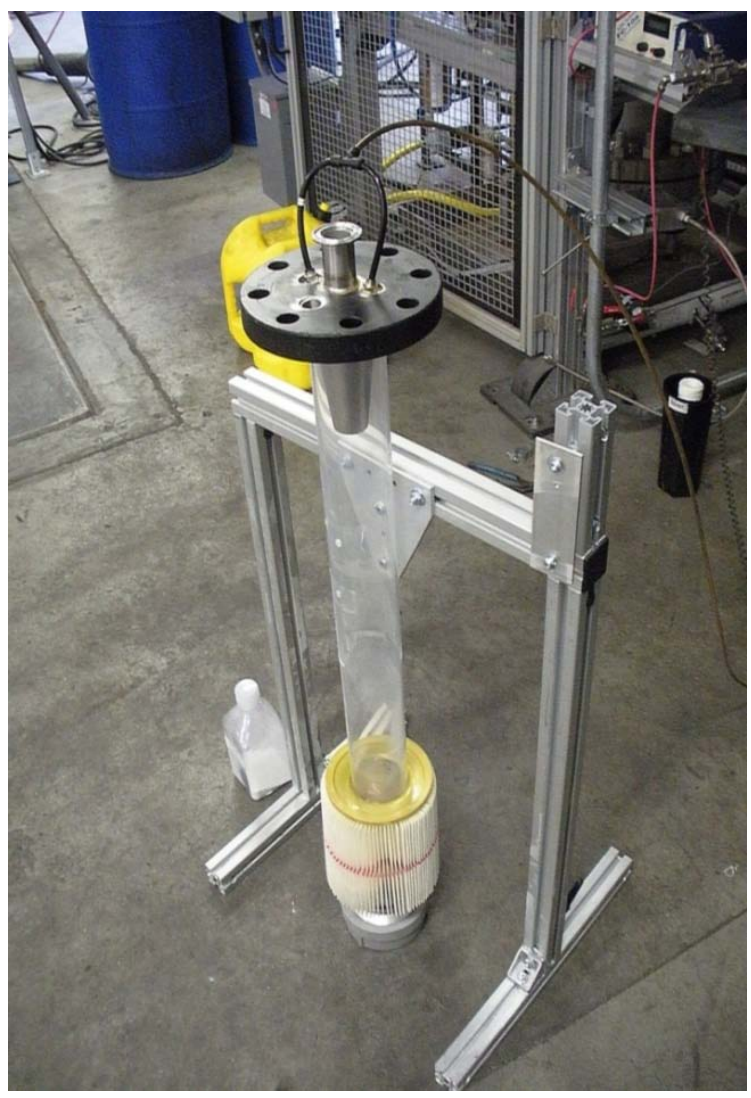

Figure 2.8. Burner Head Bench Testing 


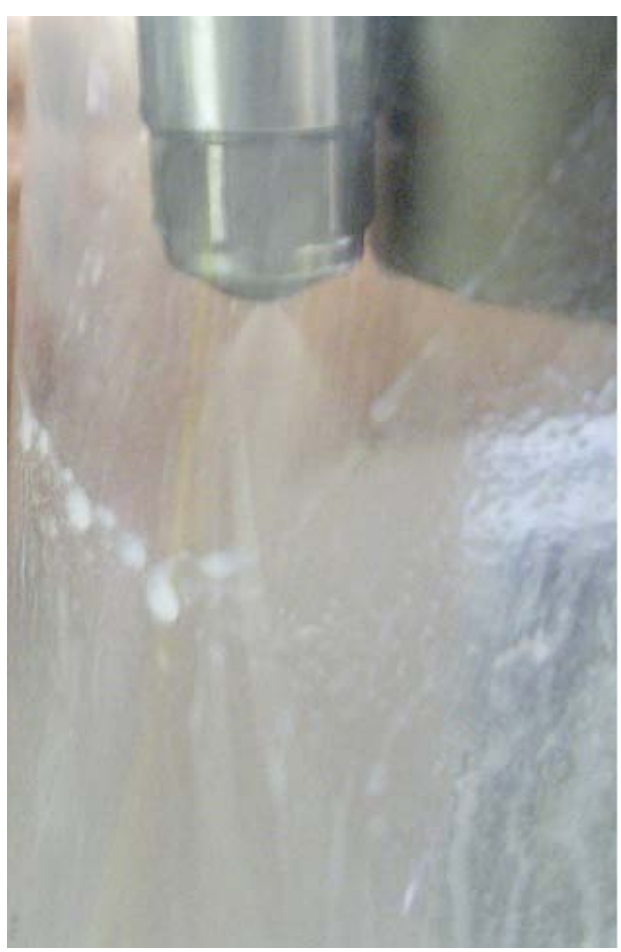

Figure 2.9. Nozzle Spray Testing in Clear Tube

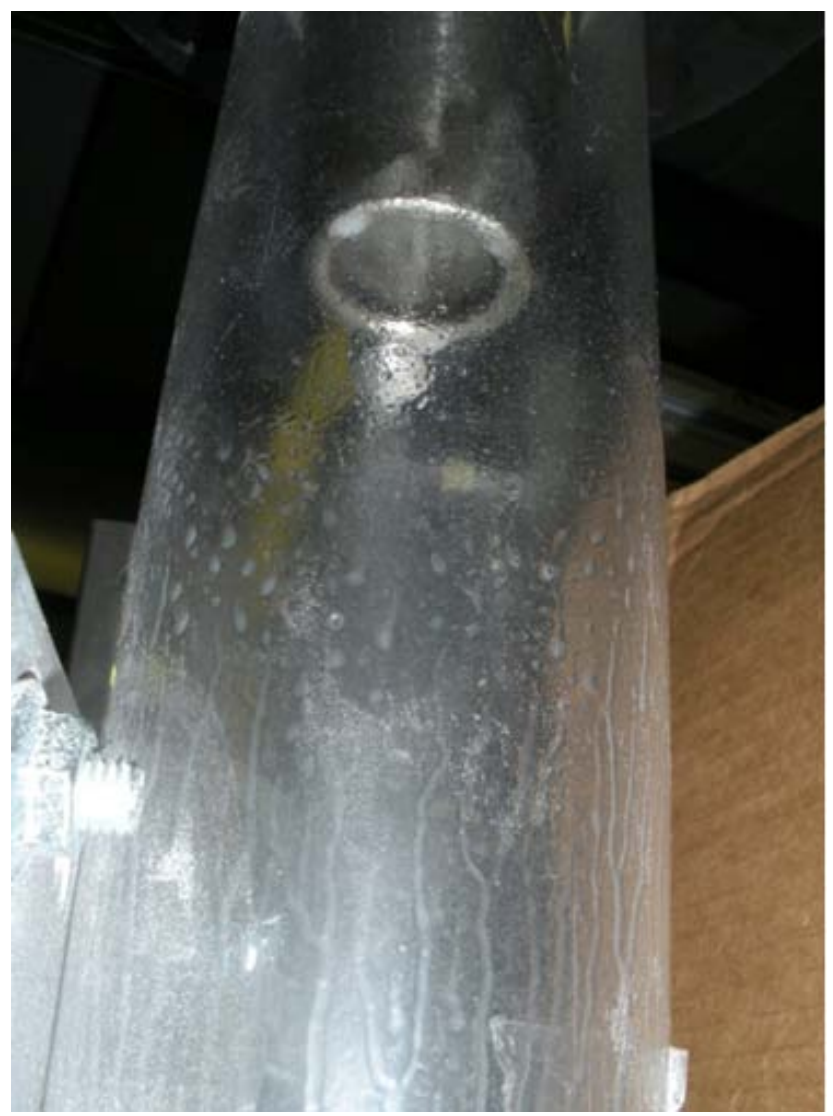

Figure 2.10. Nozzle Spray Pattern Observed 


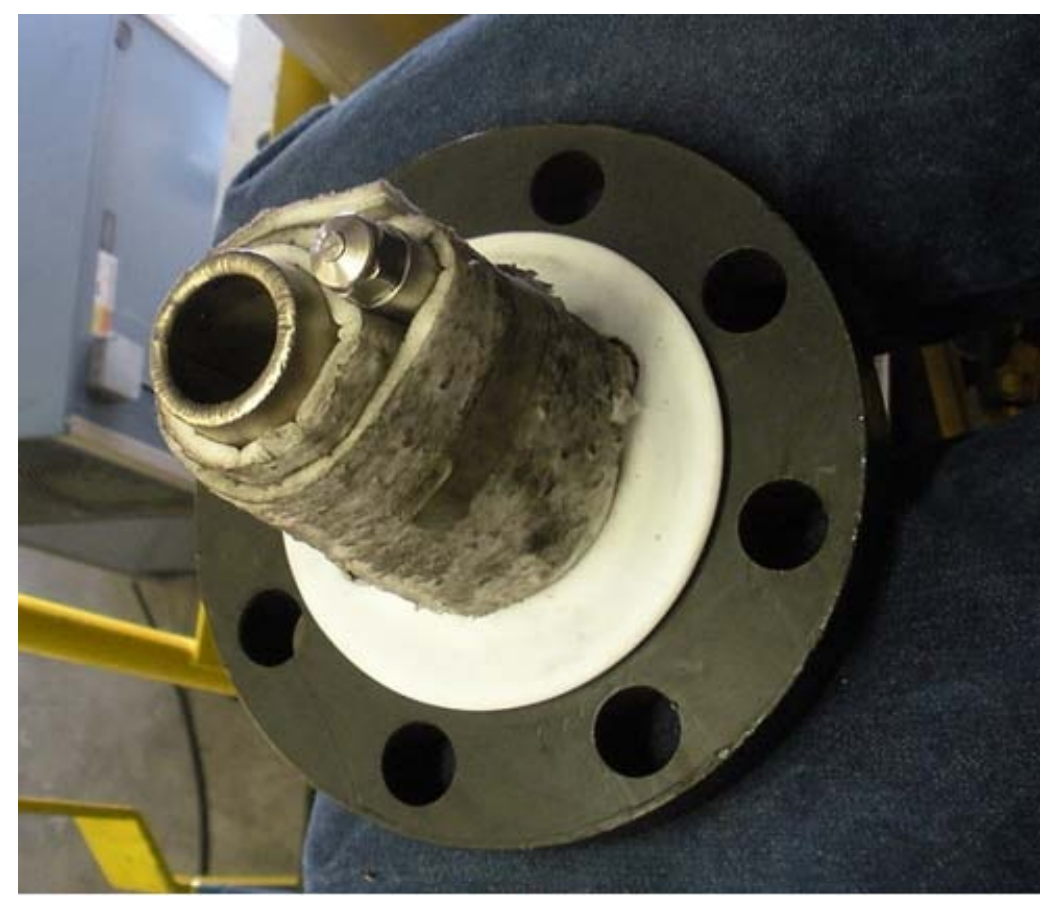

Figure 2.11. Insulated Burner

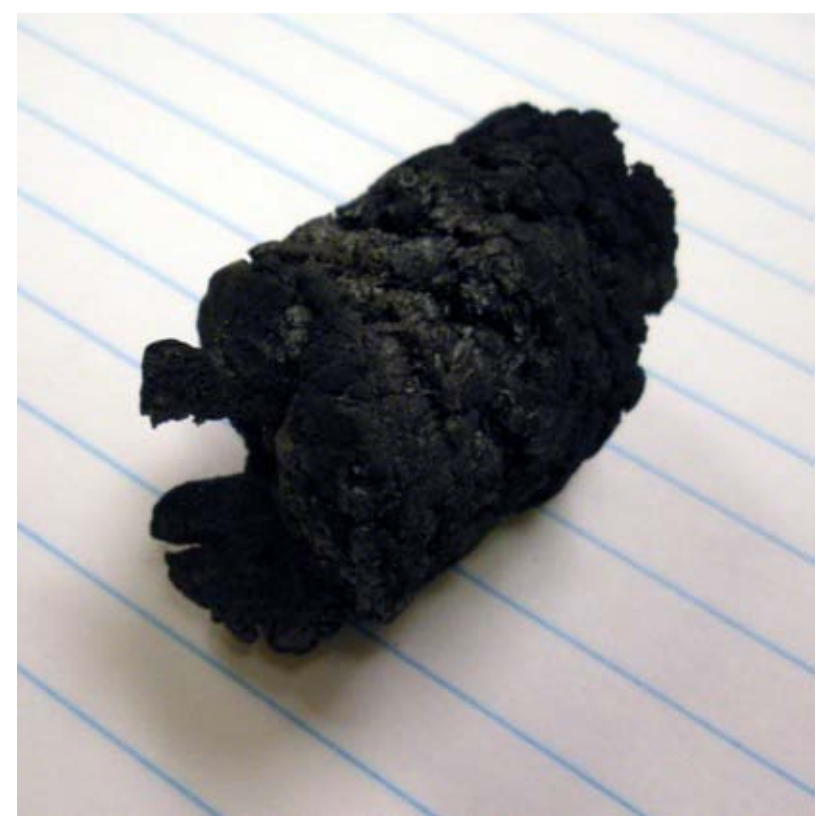

Figure 2.12. Sample Coal Plug 


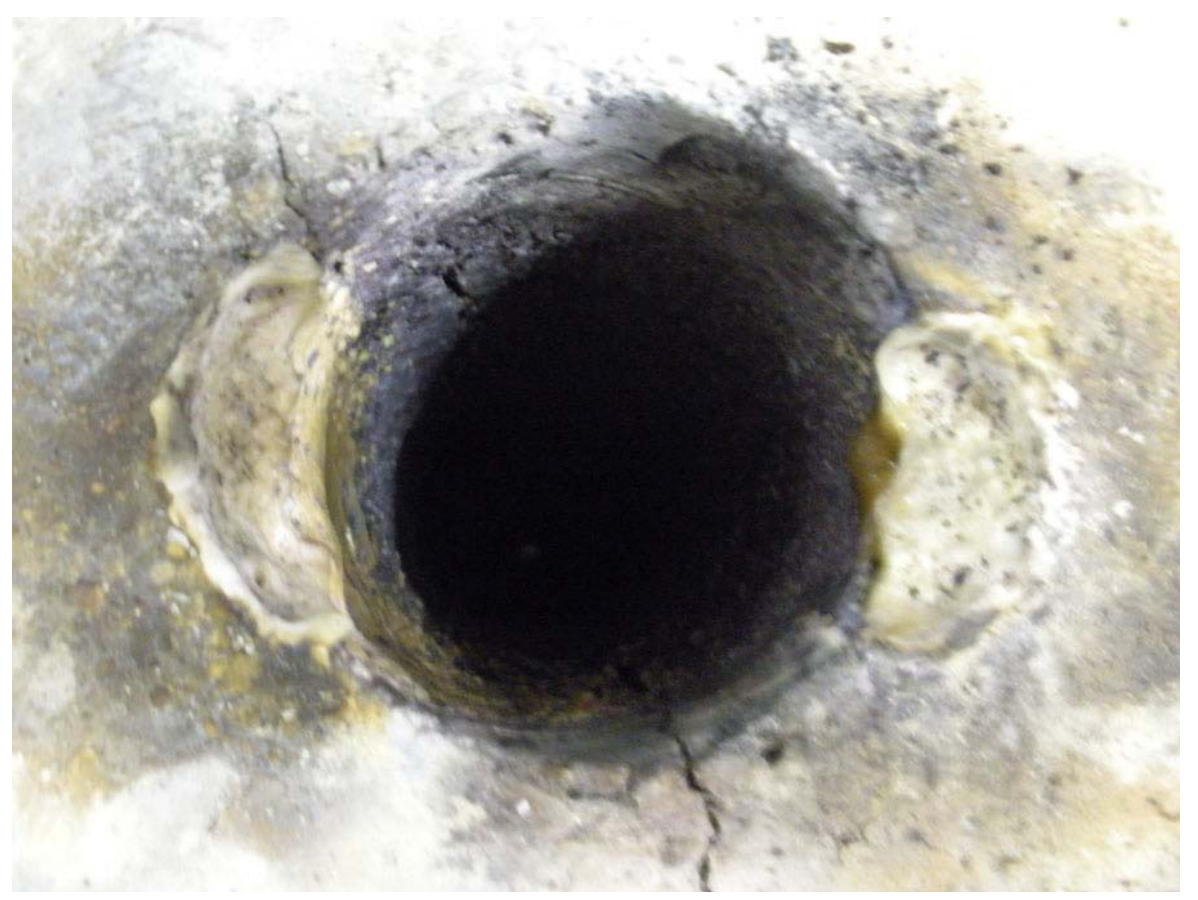

Figure 2.13. Damaged Castable

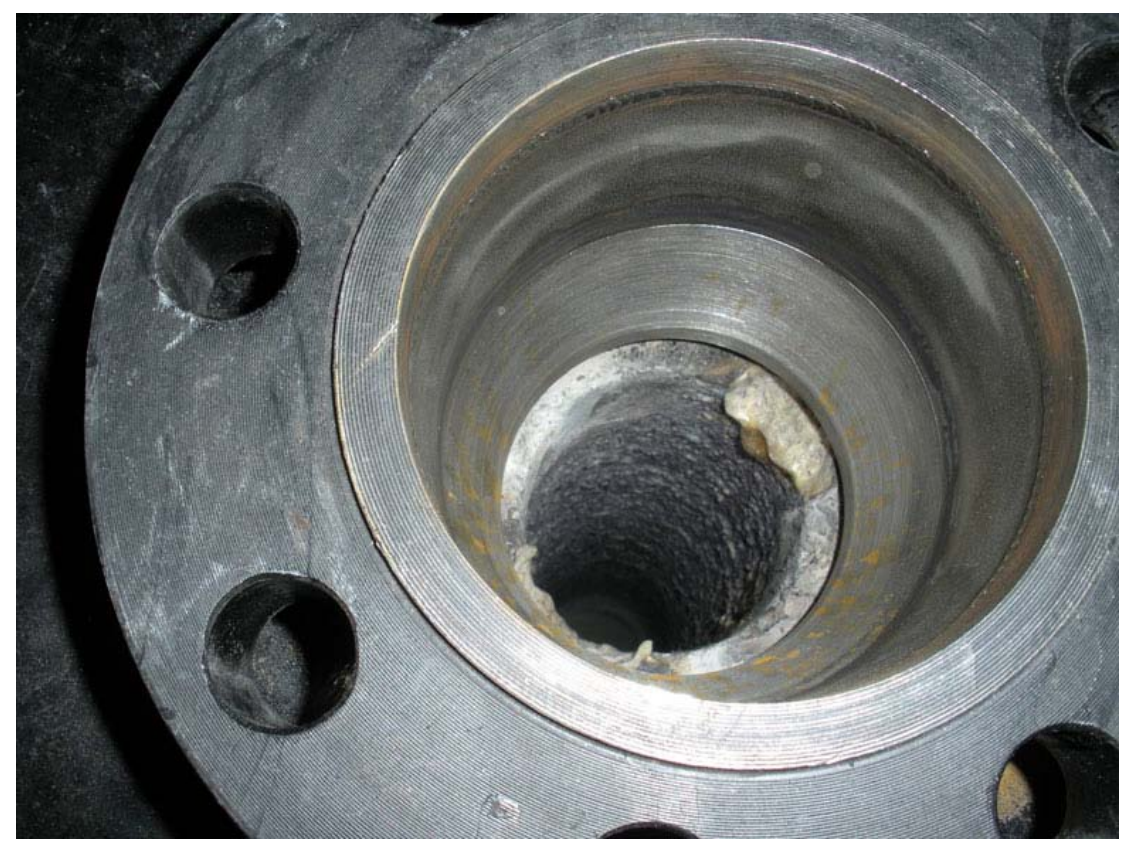

Figure 2.14. Burner Removed

A total of 9 methanol runs were performed to date. Two diesel runs were attempted before deciding to return to methanol. Dry coal was fed into the gasifier on five occasions. For the initial runs, the first iteration coal tube (Figure 2.6) was used. In the $5^{\text {th }}$ and most successful run, the feed holes were relocated to the extreme bottom of the coal feed tube, where the reducer is welded on. The four relocated nozzle holes were increased to a diameter of $3 / 32$ inch and pointed vertically down, parallel to the gasifier walls.

Figure 2.15 shows the most recent burner head design after a methanol and coal run. 


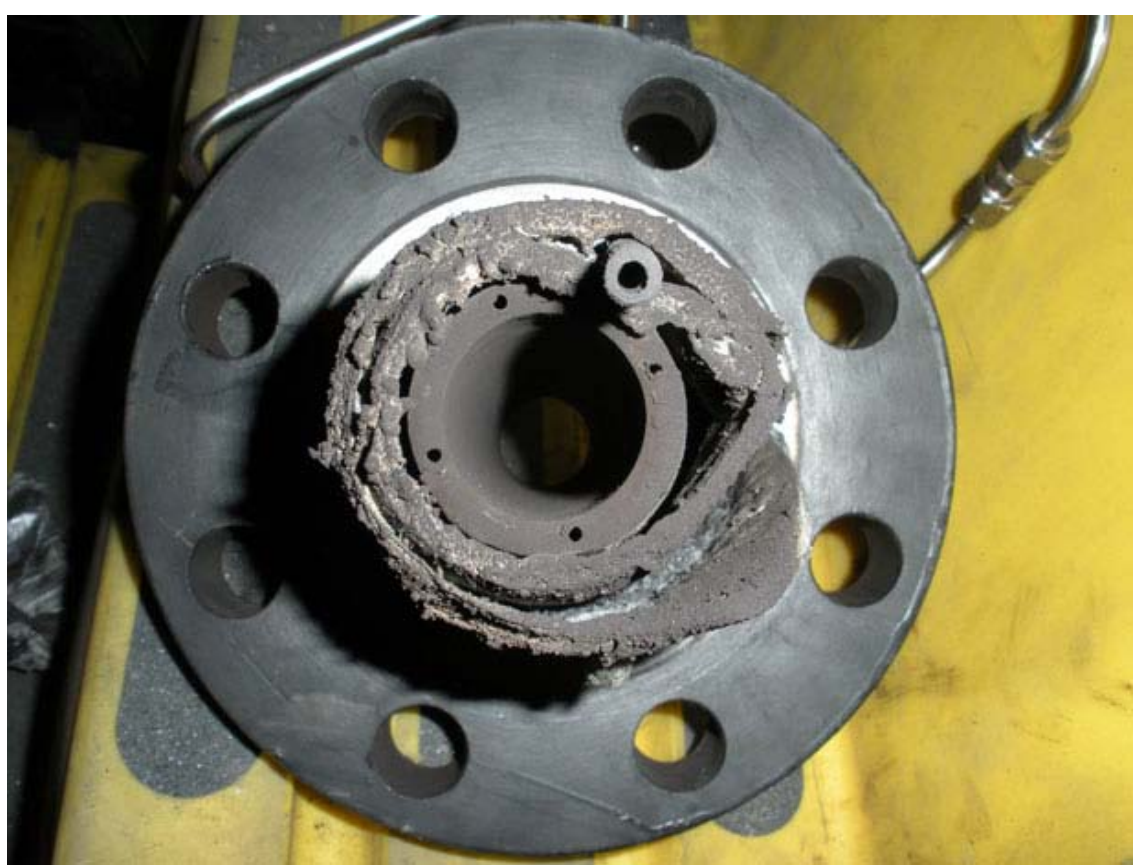

Figure 2.15. Burner Head after Coal Run in February 2010

\subsection{Sensitivity Analysis}

A sensitivity analysis was performed during a methanol run. Additional sensitivity analysis will be performed during the future gasifier run including coal runs. Sufficient runs have been performed to date to establish an effective heat up procedure. In general, the procedure involves ramping up heat in the gasifier no more than $150^{\circ} \mathrm{C}\left(302^{\circ} \mathrm{F}\right)$ per hour by observing thermocouple readings. The goal is to gradually feed less methanol and more coal. Ultimately a $100 \%$ coal feed is desired. The highest mass ratio of methanol to coal reached to date is 0.27 at steady state. Chemical composition and empirical evidence indicate that as the coal feed ratio increases, the carbon content increases, and as the methanol feed ratio increases, the hydrogen content increases. One percent adjustments are made to the input parameters approximately every five minutes. The procedures were designed to keep the gasifier below stoichiometry for combustion. The following steps outline the process to reach stable conditions where sensitivity studies can be performed. Refer to Table 2.2 for feed rate unit conversions.

- Heat up bore to about $600^{\circ} \mathrm{C}\left(1,112^{\circ} \mathrm{F}\right)$ with heating rod

- Install the burner head and start feeding $40 \%$ methanol fuel and $20 \%$ oxygen

- After a gradual ramp up in temperature, a 36\% methanol fuel and 24\% oxygen ratio is where coal can be introduced at about $8 \%$.

- Eventually the methanol fuel should be $26 \%$, oxygen $26 \%$, and coal $14 \%$

- Begin sensitivity analysis.

The percent inputs refer to the PLC controls. Units of scfm refer to standard cubic feet per minute, and slpm refers to standard liters per minute. 
Table 2.2. Fuel Input Conversion Quick Reference

\begin{tabular}{cccc}
\hline \multicolumn{4}{c}{ Methanol Fuel Feed } \\
\hline \% Flow & $\mathbf{~ m l / m i n}$ & $\mathbf{l b} / \mathbf{h r}$ & $\mathbf{s c f m}$ \\
25 & 72 & 7.5 & 2.04 \\
50 & 140 & 14.7 & 3.96 \\
75 & 210 & 22.1 & 5.95 \\
100 & 280 & 28.6 & 7.93 \\
\multicolumn{5}{c}{ Oxygen Feed } \\
\% Flow & slpm \\
25 & 50 \\
50 & 100 \\
100 & 203 & \\
\multicolumn{4}{c}{ Coal Feed } \\
\% Output & $\mathbf{l b} / \mathbf{h r}$ \\
10 & 6.6 \\
20 & 12.6 \\
30 & 18.6 \\
\hline
\end{tabular}

The uncertainty of all the instruments reading the various inputs and outputs must be considered before experimentation can begin. To the extent possible each instrument was calibrated and checked for accuracy and precision. Accuracy is important because it refers to the agreement between a measurement and the true or correct value. Precision is also important because it refers to the repeatability of measurement.

Table 2.3 shows the accuracy of each of the parameter data recording instruments used, and the operating range for which it is valid.

Table 2.3. Instrumentation Uncertainty/Parameter Accuracy

\begin{tabular}{lcc}
\hline \multicolumn{1}{c}{ Instrumentation } & $\begin{array}{c}\text { Uncertainty / Parameter } \\
\text { Accuracy }\end{array}$ & $\begin{array}{c}\text { Valid in This Operating } \\
\text { Range }\end{array}$ \\
\hline K-Type Thermocouples & $+/-0.1^{\circ} \mathrm{C}$ & -200 to $1,250{ }^{\circ} \mathrm{C}$ \\
Methanol pump & $+/-0.18 \mathrm{lb} / \mathrm{hr}$ & 8 to $12 \mathrm{lb} / \mathrm{hr}$ \\
Coal auger & $+/-0.6 \mathrm{lb} / \mathrm{hr}$ & 6 to $12 \mathrm{lb} / \mathrm{hr}$ \\
Oxygen feed & $+/-1$ Liters per minute & 40 to $80 \mathrm{Liters} \mathrm{per} \mathrm{minute}$ \\
Nitrogen feed & $+/-0.1 \mathrm{scfm}$ & 1 to $2.5 \mathrm{scfm}$ \\
Syngas readings from & & \\
InEnTec's NOVA instrument & $+/-0.2 \%$ & Any \\
\hline
\end{tabular}

Figure 2.16 shows the locations of the thermocouples. They are referred to as TC1, TC2, TC3, and TC4. The tip of each thermocouple was installed 1-inch from the inside surface of the gasifier bore. 


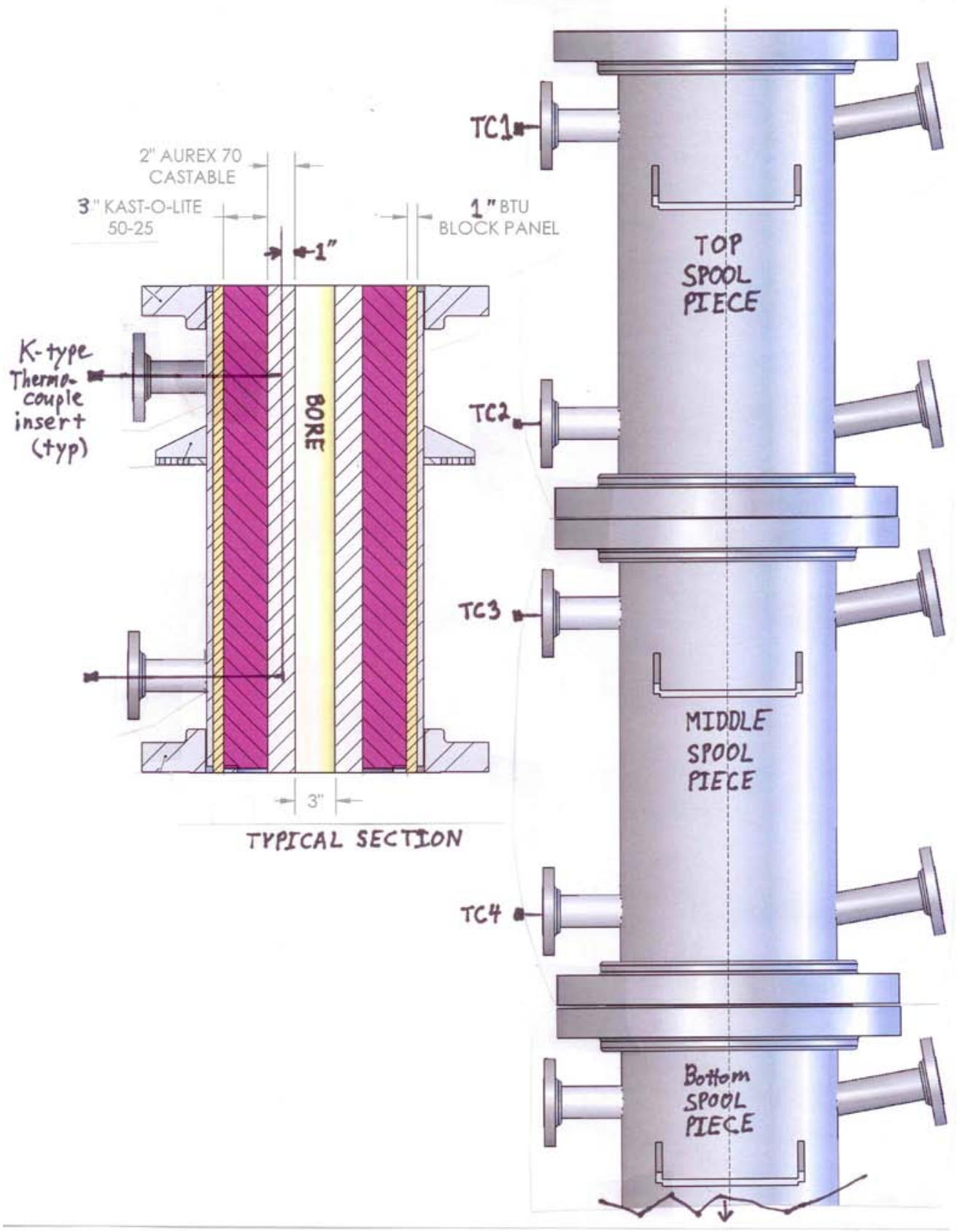

Figure 2.16. Thermocouple Locations

Appendix L relates the oxygen flow percentage reading from the PLC to a slpm flow rate. Appendix $\mathrm{M}$ relates the methanol flow percent reading from the PLC to a lb/hr rate. Appendix $\mathrm{N}$ relates the coal flow percent reading from the PLC to a lb/hr rate. The oxygen, methanol, and coal are assumed to be at standard temperature and pressure. Appendix $\mathrm{O}$ contains the results of the sensitivity analysis for a methanol run in February 2010. In this run, methanol was fed until the gasifier temperatures were high enough to begin feeding coal. Section 3.2 contains a discussion and picture of the coal plug that stopped the coal feed after about 20 minutes. 
The output syngas readings are measured and displayed by the NOVA instrument on a percent volume basis. The NOVA instrument is maintained and calibrated by the InEnTec facility. Moisture is removed by a wet scrubber before it goes to the NOVA. Previous to, and including this last sensitivity run, the flow meter on the NOVA was not functional. Although the flow meter has been repaired, the percentage of gas measured by NOVA is vented separately and not measured as part of gas going through flow meter. Currently there is no capability to measure the caloric value of the syngas. With the specific setup and instrumentation available at this gasifier an elemental mass balance is not possible. There are many factors that prevent an exact measure of the carbon conversion and syngas production. In the future, PNNL will develop the capability to quantify the carbon content captured in the water bath. An accurate measure of the calorific content of the syngas is also needed. In the future PNNL plans to bottle the syngas for internal customers. When gas bottling occurs it will be feasible to send a sample to be tested for its caloric value.

Table O-1A reports the fuel sensitivity data for 1-\% incremental increases in methanol fuel. All other inputs remained constant. The nitrogen feed was held at $1.2 \mathrm{scfm}$, and the oxygen was constant at $18 \%$. Table O-1B shows the net change in each of the syngas constituents over the entire 20 minute test. Table O-1C shows the gasifier temperature profile for which this test is valid. Figure O-1 plots the output syngas data from Table N-1A with time in minutes on the $\mathrm{x}$-axis and volume $\%$ on the $\mathrm{y}$-axis. Figure $\mathrm{O}-2$ plots the output syngas ratio data from Table O-1A with time in minutes on the $\mathrm{x}$-axis, and volume $\%$ on the y-axis. In both Figure O-1 and O-2, a step function showing the methanol \% input is overlaid to show the discrete points in time where adjustments were made to the methanol input. The actual methanol percent values are printed next to each change in the step function for clarity.

Table O-2A reports the fuel sensitivity data for 1-\% incremental increases in oxygen flow. All other inputs remained constant. The nitrogen feed was held at $1.2 \mathrm{scfm}$, and the methanol was constant at $24 \%$. Table O-2B shows the net change in each of the syngas constituents over the entire 15 minute test. Table O-2C shows the gasifier temperature profile for which this test is valid. Figure O-3 plots the output syngas data from Table O-2A with time in minutes on the $\mathrm{x}$-axis, and volume $\%$ on the $\mathrm{y}$-axis. Figure $\mathrm{O}$ 4 plots the output syngas ratio data from table $\mathrm{O}-2 \mathrm{~A}$ with time in minutes on the $\mathrm{x}$-axis and volume $\%$ on the y-axis. In both Figure O-3 and O-4, a step function showing the oxygen \% input is overlaid to show the discrete points in time where adjustments were made to the methanol input. The actual oxygen percent values are printed next to each change in the step function for clarity.

Several conclusions can be drawn from the sensitivity analysis data in Appendix O

A given percentage change in methanol has more of an impact on the output syngas composition than the same percentage change in oxygen. When the methanol is increased the fuel to oxygen mixture becomes fuel rich, and the $\mathrm{CO}$ to $(\mathrm{CO}+\mathrm{CO} 2)$ ratio increases, thus indicating more incomplete combustion in the gasifier. A higher $\mathrm{CO}$ to $(\mathrm{CO}+\mathrm{CO} 2)$ ratio is desirable when the intended output is a syngas with high combustible content. The $\mathrm{CO}$ to $\mathrm{H} 2$ ratio is an indication of the formation of free radicals and cannot be used directly to predict quantitatively the calorific value of the syngas generated. 


\subsection{Technical Challenges}

\subsection{Fuel Feed}

The current pulverized coal auger feed design does not deliver a consistent feed rate because the coal powder has a tendency to clump. Additionally at low speed corresponding to low flow rates, the feeder is observed to jump. Bucket and stop watch calibration have shown that on average the feeder is reasonably reliable. Figure 3.1 shows the top of the gasifier including a close-up of the coal auger scroll feed. An alternative slurry feed system under consideration has been designed to replace the current dry coal delivery system. Modifications to dry feed are currently being pursued before consideration of slurry feed.

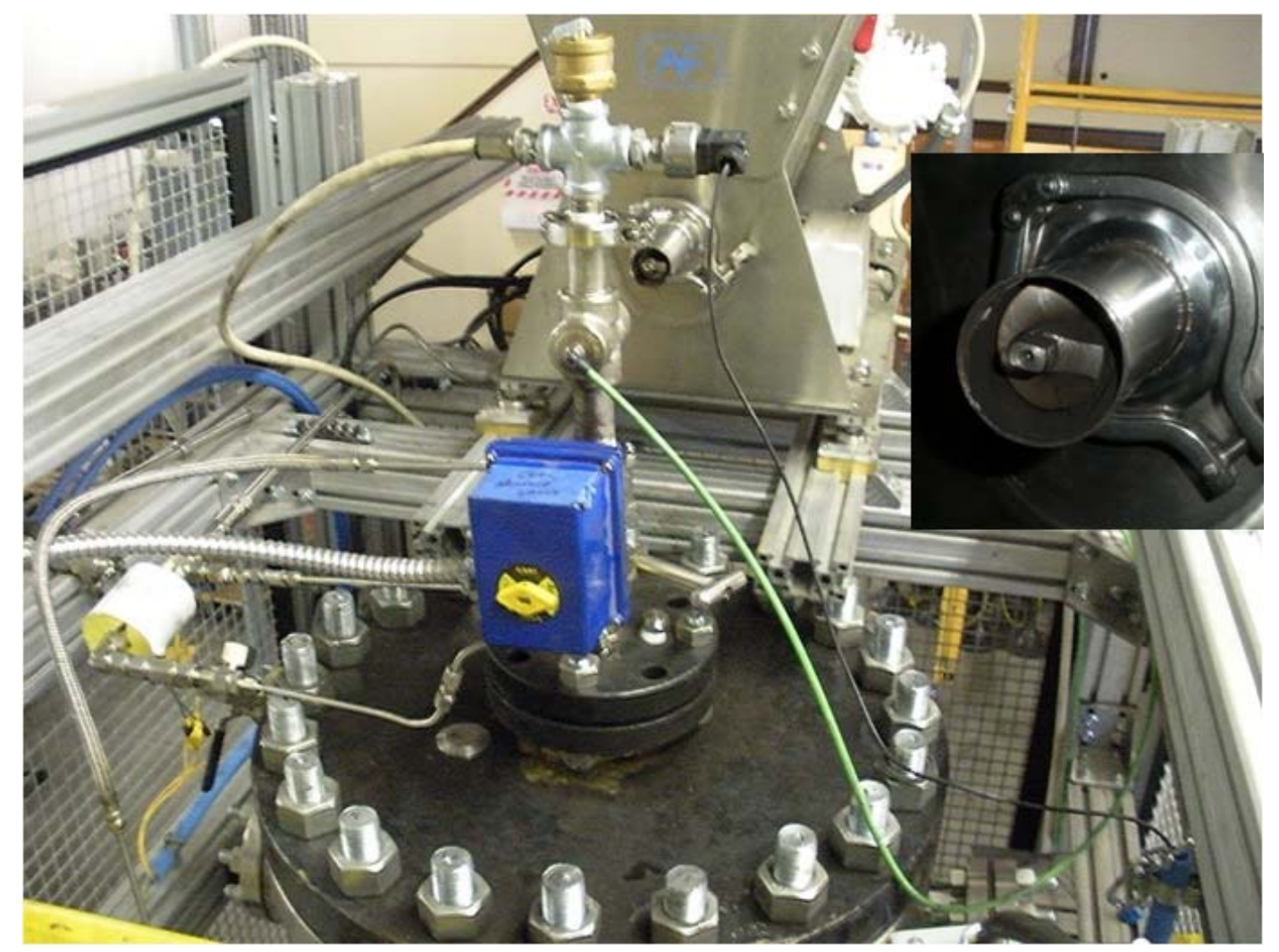

Figure 3.1. Coal Auger Scroll Feed

Diesel fuel was evaluated as an alternative to methanol because of its higher energy content. Gasifying with diesel fuel presented many problems. During testing, sufficient oxygen was not supplied resulting in incomplete combustion of the diesel. The water basin became contaminated with diesel and created a dirty cleanup and disposal scenario. Additionally, diesel has much higher viscosity than methanol, thus making it a less attractive candidate for slurry feed. The syngas composition is significantly more affected by feeding diesel than to methanol. Thus methanol is preferred for start up and normal operation of the gasifier. 


\subsection{Gasifier Temperatures}

Another unexpected problem is evidenced by the large temperature fluxuations shown in Appendix C. Sudden changes in temperature can cause unacceptable thermal expansion and contraction leading to cracking of the gasifier vessel. Appendix $\mathrm{C}$ also shows five times where analytics caused issues. Sensors were tripped due to high oxygen levels causing delays in the continuity of fuel feed. This is evidence of incomplete mixing. Figure 3.2 shows how the bore became plugged from coal build up half-way down the gasifier. This problem is also a temperature delta problem, which causes the slag to cool too rapidly before encountering the water bath at the bottom of the gasifier.

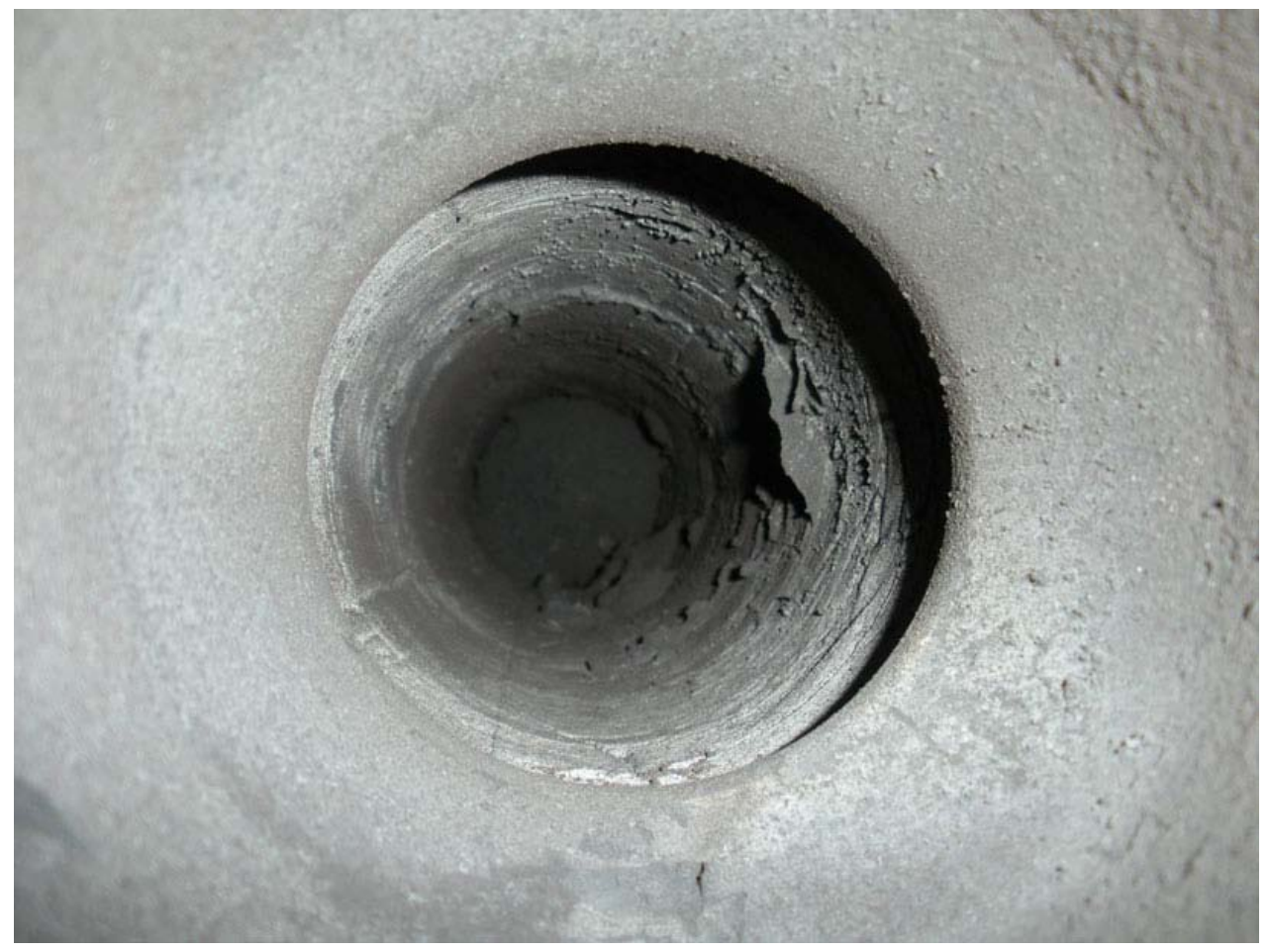

Figure 3.2. Bore Plugged up February 2010

\subsection{Syngas Analysis}

Initially, a Sable Systems oxygen analyzer (Figure 3.3) was purchased for sampling and analyzing the off-gas stream for oxygen content. The gas traps installed to filter the syngas prior to the Sable sub-sampler became plugged too frequently to be relied on for the critical oxygen alarms. After testing and experimentation, it was determined that the NOVA instrument provided by InEnTec would be used to measure syngas composition. Oxygen high alarms were provided by the NOVA system because the lag time was significantly less than the Sable system. 


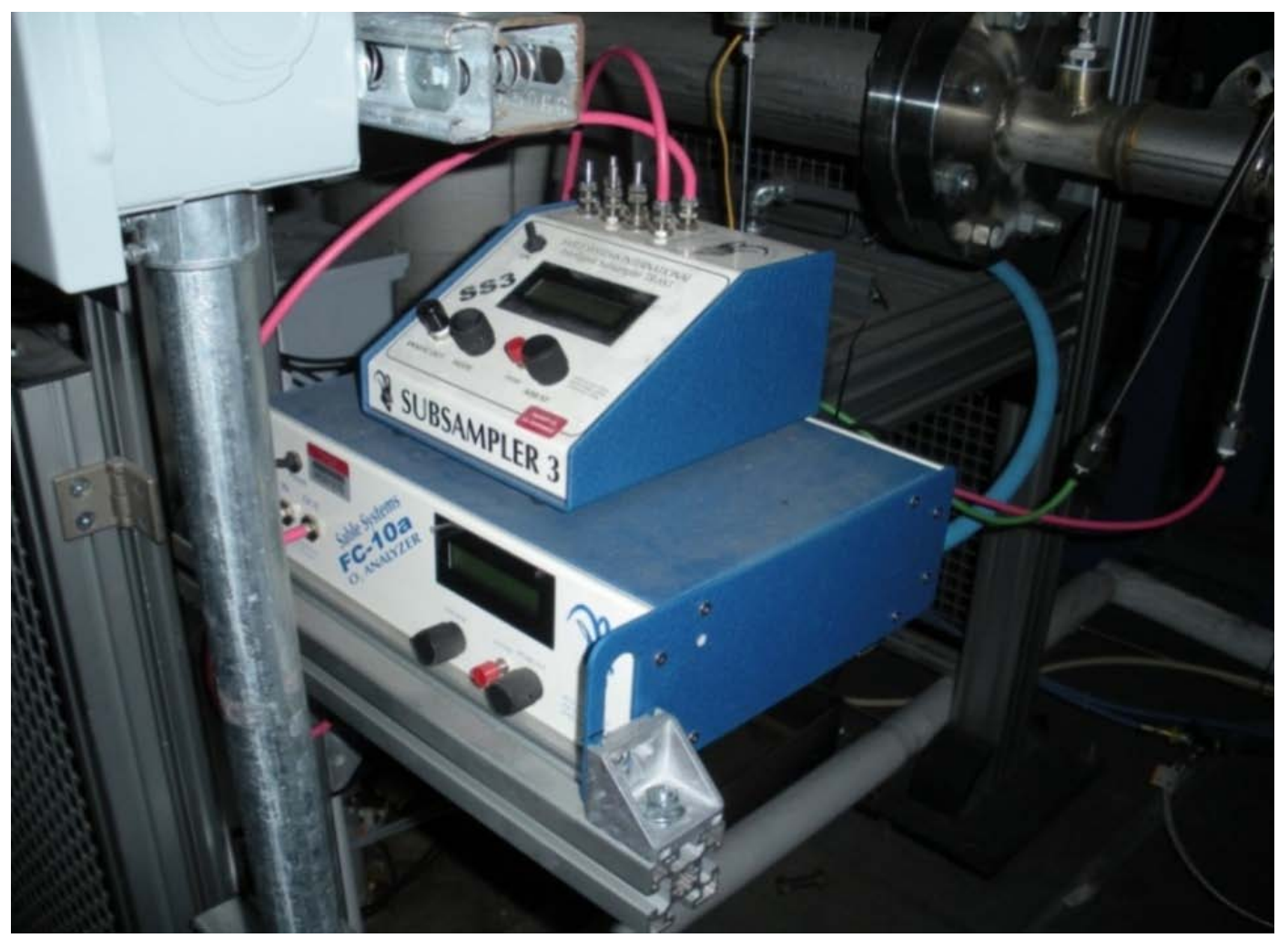

Figure 3.3. Sable Oxygen Analyzer

Figure 3.4 shows the path of the off-gas stream from the gasifier.

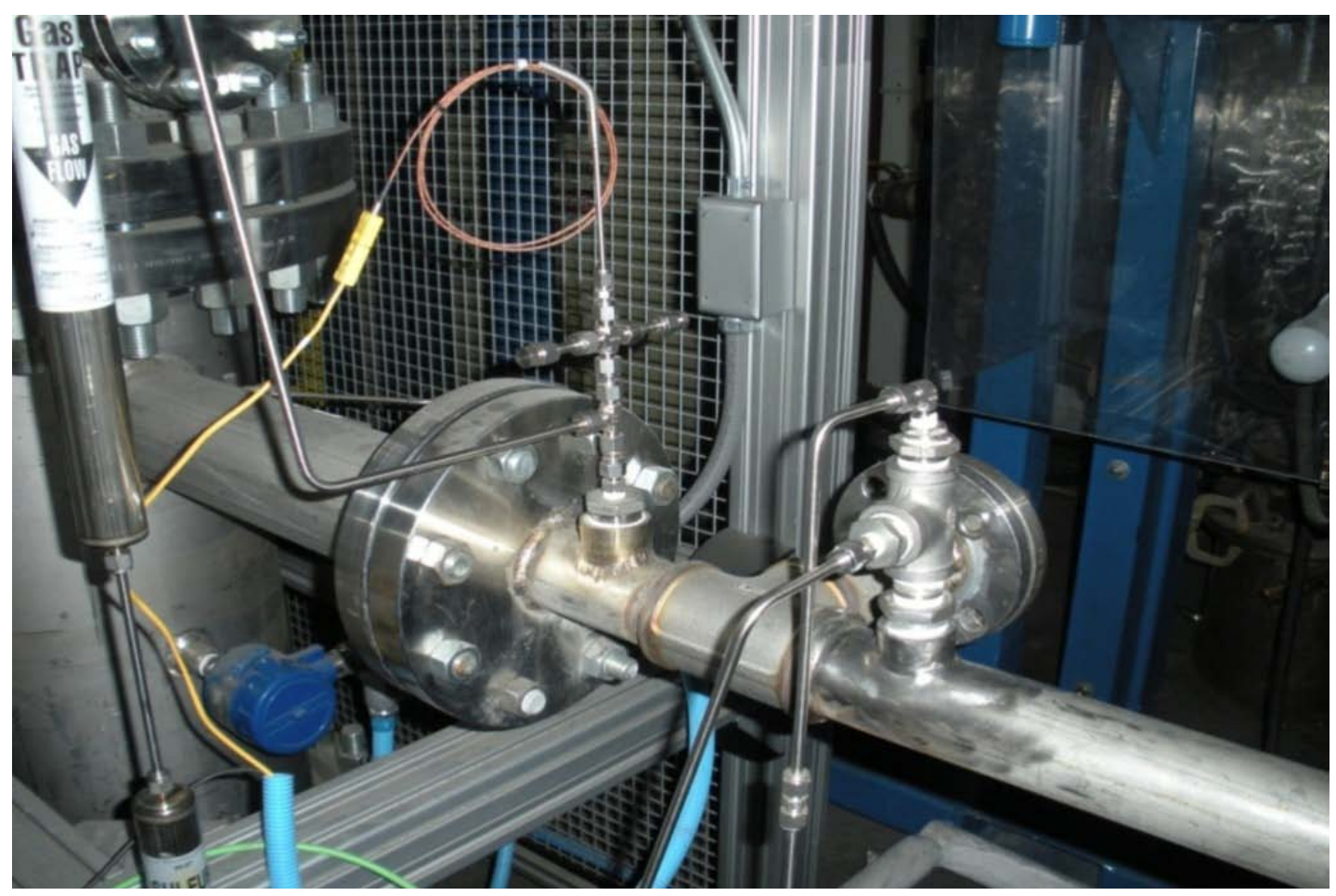

Figure 3.4. Off-Gas Stream 



\subsection{Lessons Learned}

In the process of encountering the technical challenges of running the gasifier, many lessons were learned. One challenge encountered at InEnTec was limited facility space. If future funding allows, a larger space will be used to facilitate easier access to the gasifier. Another important lesson learned was that gasifying with methanol is preferable to diesel in this application for reasons described in Chapter 3. Also, the challenges of technology scaling became evident. The predictions for full scale operation do not easily translate to engineering scale. Relying on the upper pressure gauge to determine the basin water level was a temporary solution to the fouled limit switches. More reliable water level sensors will be installed for future runs.

The original refractory liner was rated for lower temperatures than the intended operation of the gasifier. New material was purchased, and new spool pieces were fabricated.

The current feed system and gasifier setup does not allow for sustained run time. The feed system must be continually modified and improved to allow longer run times.

Predicted results from analytical models must ultimately be validated with experimentation. A cost benefit analysis must be performed when determine whether analytical modeling is justified prior to experimentation. When a limited budget is involved, the risk of damaging equipment must be weighed against the time and cost of extensive modeling and engineering analysis. 



\subsection{Conclusions and Recommendations for Future Work}

At the conclusion of commissioning, proof of principle was achieved for a modified burner that delivers coal and methanol to the gasifier (see Figure 1.1). Bench testing for fuel constituent mixing was completed, followed by successful demonstration in the gasifier vessel itself. As the project progresses, future gasifier runs will be prioritized and aligned with PNNL research objectives. These primary future objectives include providing syngas to researchers by pressurizing and bottling samples and by ensuring syngas composition is appropriate for customer needs.

Increased residence time for the fuel is needed. By observing the amount of particulate in the water we know there is still a lot of fixed carbon in the quench solids. A material balance suggests only about $30 \%$ of the carbon that is fed into the gasifier is accounted for in the syngas. This calculation is inexact due to current feed rate and syngas measurements. The possibility of increasing the bore size on the upper two spool pieces has been considered. Increasing the feed path length by way of swirling may be achieved by a fuel feed design modification. The possibility of installing a fire eye has been left open pending sufficient need and budget. To facilitate a reliable and consistent feed rate, a slurry feed capability was also considered.

In the current configuration, the engineering scale gasifier does not support highly pressurized operation. Future testing of a bench top setup will evaluate delivery of coal methanol slurry into an atmospheric gasifier. When diesel was under consideration as a fuel source, a slurry sample was sent to Moyno Industrial for analysis [15]; Appendix $\mathrm{H}$ shows the test results. When methanol was ultimately chosen for the slurry feed, the results from Appendix H were consulted to size a pump. Methanol's specific gravity is less than diesel, and there was no time to wait for another analysis before a pump was ordered. Appendix I shows viscosity in centipoise on the y-axis and velocity in $\mathrm{ft} / \mathrm{sec}$ on the $\mathrm{x}$-axis. Basic velocity calculations were performed for the new head design resulting in a maximum anticipated feed rate of 12 pounds an hour. The resultant velocity of the slurry through the 0.25 -inch feed line and the 0.03 -inch diameter fuel post is $0.0011 \mathrm{ft} / \mathrm{sec}$ and $10.9 \mathrm{ft} / \mathrm{sec}$, respectively. These values lie on the extreme ends of the Moyno viscosity curve, shown in Appendix H. The pump ordered has nitrile o-rings and is chemically compatible with methanol, as defined in [13].

Appendix D depicts the thermal profile of the four thermocouples versus time in hours and minutes. One of the ongoing design goals is to move the flame front further down in the vessel. When this is achieved, the temperature profile of thermocouple 1 and 2 will more closely match. Future burner designs aim to move the thermal energy further down the gasifier.

Additional sensitivity runs need to be performed to better understand the affects that a given change in the input has on the output syngas composition. Sensitivity data similar to appendix O must be gathered for changes in all input parameters, and preferably during longer duration tests. 



\subsection{Bibliography}

1. ASTM- American Society for Testing and Materials - 2008. "Standard Practice for Estimate of the Heat Gain or Loss and the Surface Temperatures of Insulated Flat, Cylindrical, and Spherical Systems by Use of Computer Programs.” C 680-08. 2008, West Conshohocken, Pennsylvania. DOI: 10.1520/C0680-08, www.astm.org

2. Baxter, Larry. “Ash Fusion Temperatures.” Energy Laboratory Web Site. Brigham Young University, 2001. Web. Jan. 2009.

http://www.et.byu.edu/ larryb/Ash\%20Fusion\%20Temperatures_1.html

3. Chen, Lei, Nolan, Rane, and Shakeel Avadhany. "Thermodynamic Analysis of Coal-to-SNG process”. Massachusetts Institute of Technology, May 14, 2009. Web. Jan. 2010. www.mit.edu/people/leichen/Thermodynamic_Analysis_of_the_coal_to_SNG_process.pdf

4. “Chemical Compatibility Chart For Disposable Gloves.” Cole-Parmer Technical Library, 2009. Web. Jan. 2009. www.coleparmer.com/techinfo/techinfo.asp?htmlfile=ChartDisposGloves.htm\&ID=56

5. “Coal Gasification.” EcoGeneration Solutions, LLC, 2002. Web. Jan. 2009. http://www.cogeneration.net/Coal-Gasification.htm

6. “Coal and Power Systems: Gasification.” National Energy Technology Laboratory (NETL), n.d. Web. Jan. 2009. http://www.netl.doe.gov/technologies/coalpower/gasification/

7. “Gasification.” Wikipedia, the free encyclopedia, n.d. Web. Jan. 2009. http://en.wikipedia.org/wiki/Gasification

8. Harbison-Walker Thermal Modeling Web Tool. ANH Refractories Company, 2005. Web. 18 Sep 2009. http://www.hwr.com/

9. Higman, Christopher, and Maarten van der Burgt. Gasification. $2^{\text {nd }}$ ed. Burlington, MA: Elsevier, Inc., 2008. Print.

10. InEnTec Website. InEnTec LLC, 2009. Web. Jan. 2009. http://www.inentec.com/

11. Krause, Theodore. "Water-Gas Shift Catalysis.” DOE Hydrogen Program: FY 2005 Progress Report, 2005. Web. 24 Jan. 2010. http://www.hydrogen.energy.gov/pdfs/progress05/vii_f_1_krause.pdf

12. Lindeburg, Michael R. Mechanical Engineering Reference Manual for the PE Exam. $11^{\text {th }}$ ed. Belmont, CA: Professional Publications, Inc., 2001. Print.

13. "Material Safety Data Sheet: Methyl Alcohol.” Chemistry Material Safety Data Sheets, Iowa State University, 14 March 2001. Web. April. 2009. http://avogadro.chem.iastate.edu/MSDS/methanol.htm 
14. “Material Safety Data Sheet: No. 2 Diesel Fuel.” PetroCard, Inc., 2007. Web. April. 2009. http://www.petrocard.com/Products/MSDS-ULS.pdf

15. Moyno Industrial Products Website. Moyno, Inc., 2008. Web. March 2009.

http://www.moyno.com/

16. "Occupational Safety and Health Guideline for Coal Dust (Greater than or Equal to $5 \% \mathrm{SiO}_{2}$ )." Occupational Safety \& Health Administration, n.d. Web. Jan. 2009. http://www.osha.gov/SLTC/healthguidelines/coaldust-greater5percentsio2/recognition.html

17. Reid DJ, JE Cabe, and MD Bearden. 2010. PNNL Coal Gasification Research. PNNL-19606, Pacific Northwest National Laboratory, Richland, Washington.

18. Pacific Northwest National Laboratory. PNNL Gasification Project: Commissioning SOP (Methanol + Coal). Document Number: ECI-Me:Coal 1. Rev. A. Richland, WA: Pacific Northwest National Laboratory, 2009. Print.

19. "Recovery Act - Integrated Energy System with Beneficial CO2 Use.” United States Department of Energy, Office of Fossil Energy Project Fact Sheet, 2009. Web. 24 Jan. 2010. http://fossil.energy.gov/fred/feprograms.jsp?prog=all\&state=AZ

20. Rezaiyan, John, and Nicholas P. Cheremisinoff. Gasification Technologies: A Primer for Engineers and Scientists. Boca Raton, FL: CRC Press, 2005. Print.

21. Sierra Instruments. Sierra Instruments, Inc., 2010. Web. Jan. 2009. http://www.sierrainstruments.com/

22. Speight, James G. The Chemistry and Technology of Coal. $2^{\text {nd }}$ ed. Laramie, WY: CD\&W Inc., 1994. Print. 
Appendix A

Sample System Completion Log Sheet 



\section{Appendix A - Sample System Completion Log Sheet}

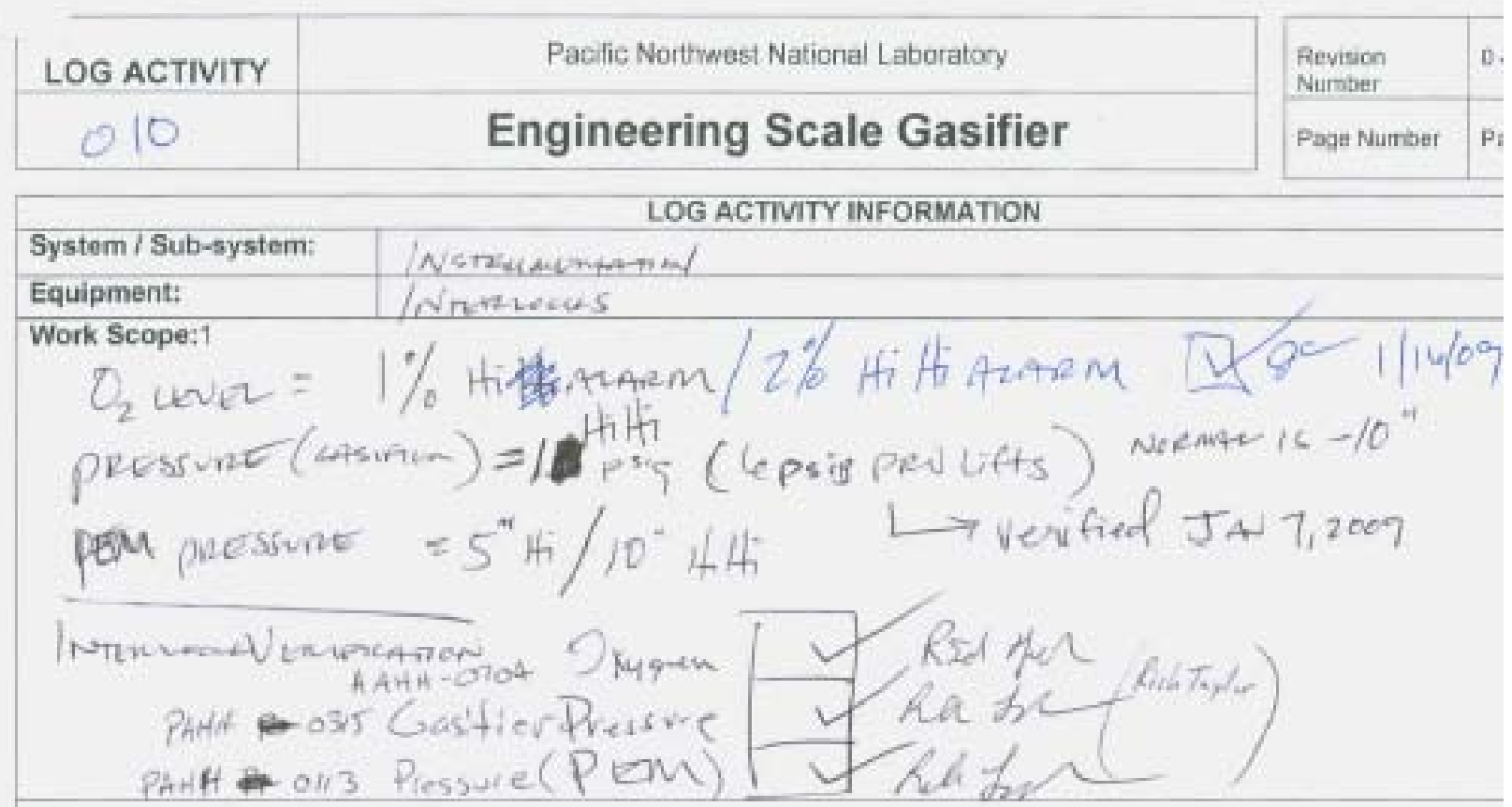

Notes:

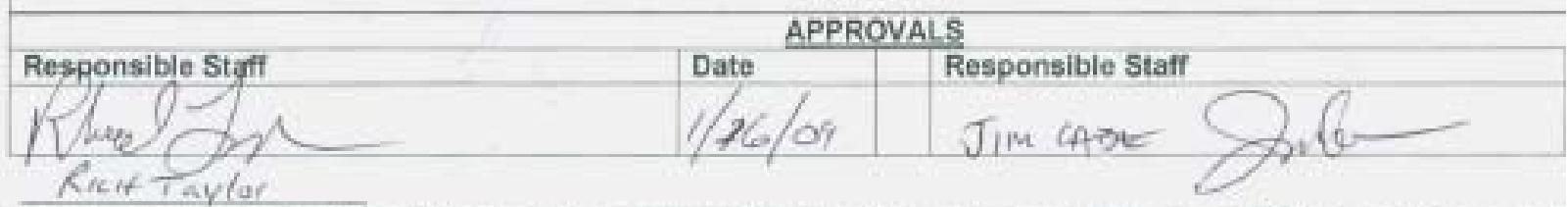

1 in a concented effort to develop revelutionary solutians and tectinclogies, ene Pacific Nouthest Naticnal Laboratory (PNNL) has desioned. cons test a novel research gasifier. This is a joint venture between PNNL and an industrial patner dintegrated Environmentil Technoiogies. Inc. (IET), 

Appendix B

\section{Thermocouple Temperatures with Methanol Fuel}





\section{Appendix B - Termocouple Temperatures with Methanol Fuel}

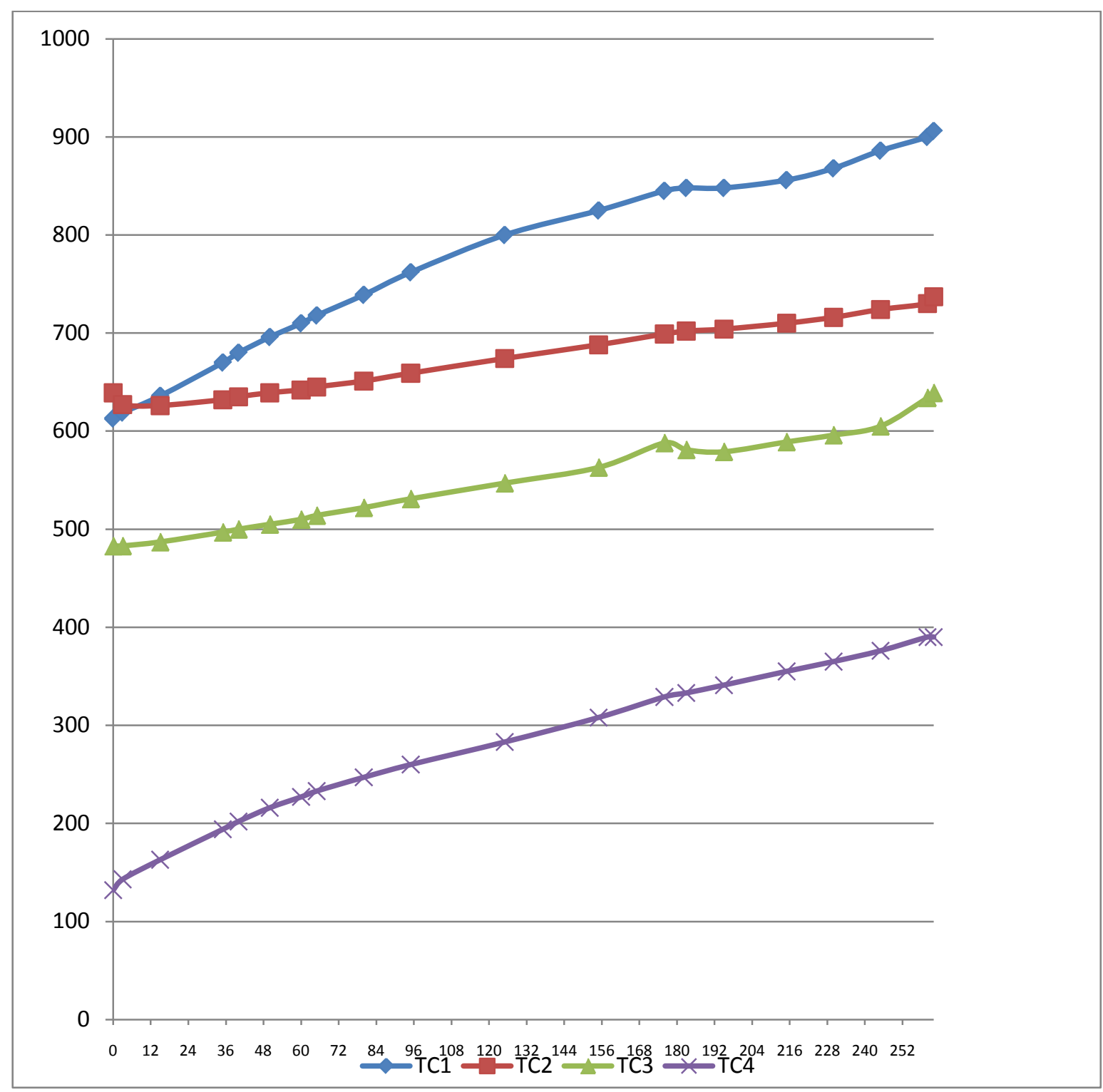



Appendix C

Thermocouple Temperatures with First Diesel Run 



\section{Appendix C - Thermocouple Temperatures with First Diesel Run}

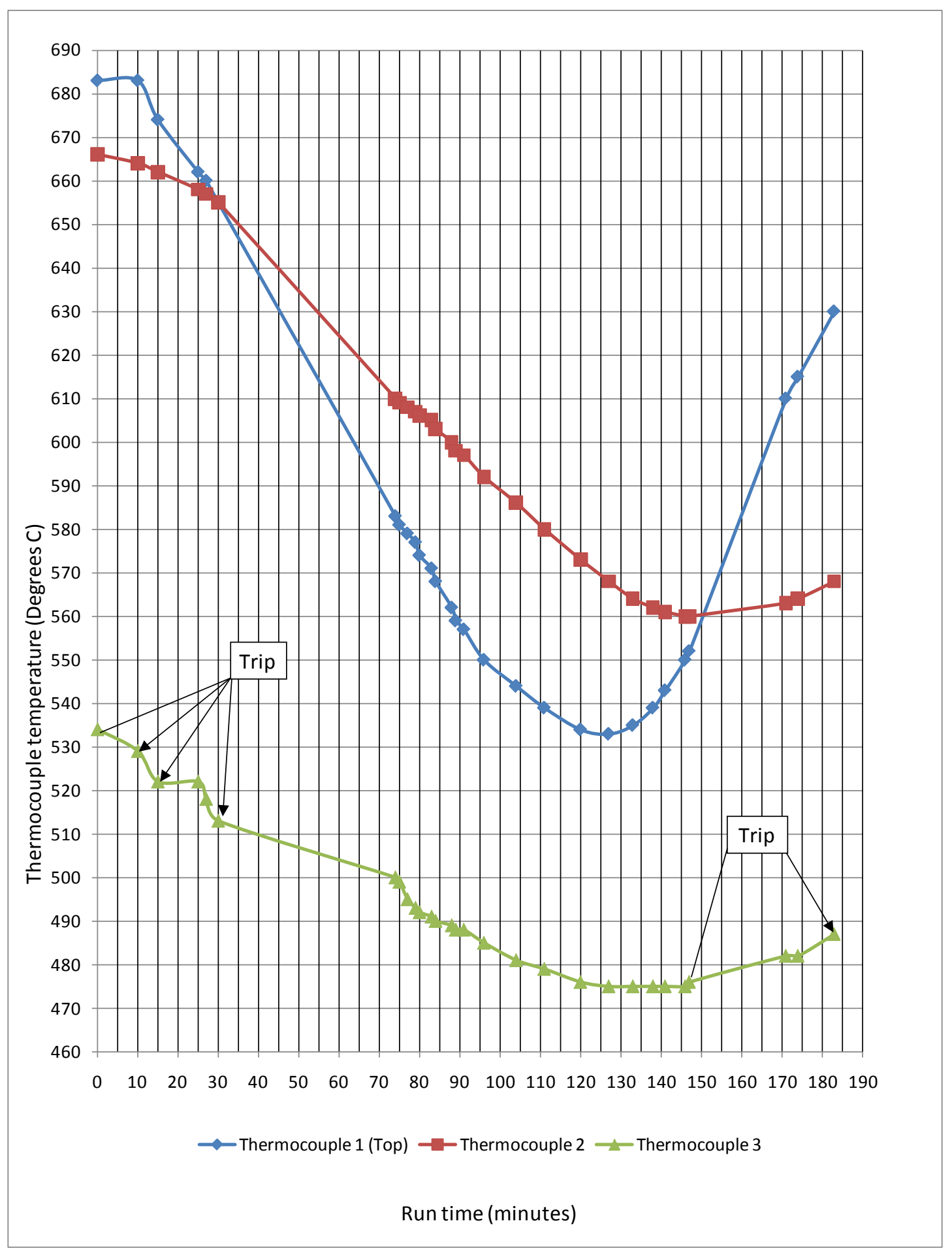

C.1 

Appendix D

First Successful Coal Run 



\section{Appendix D - First Successful Coal Run}

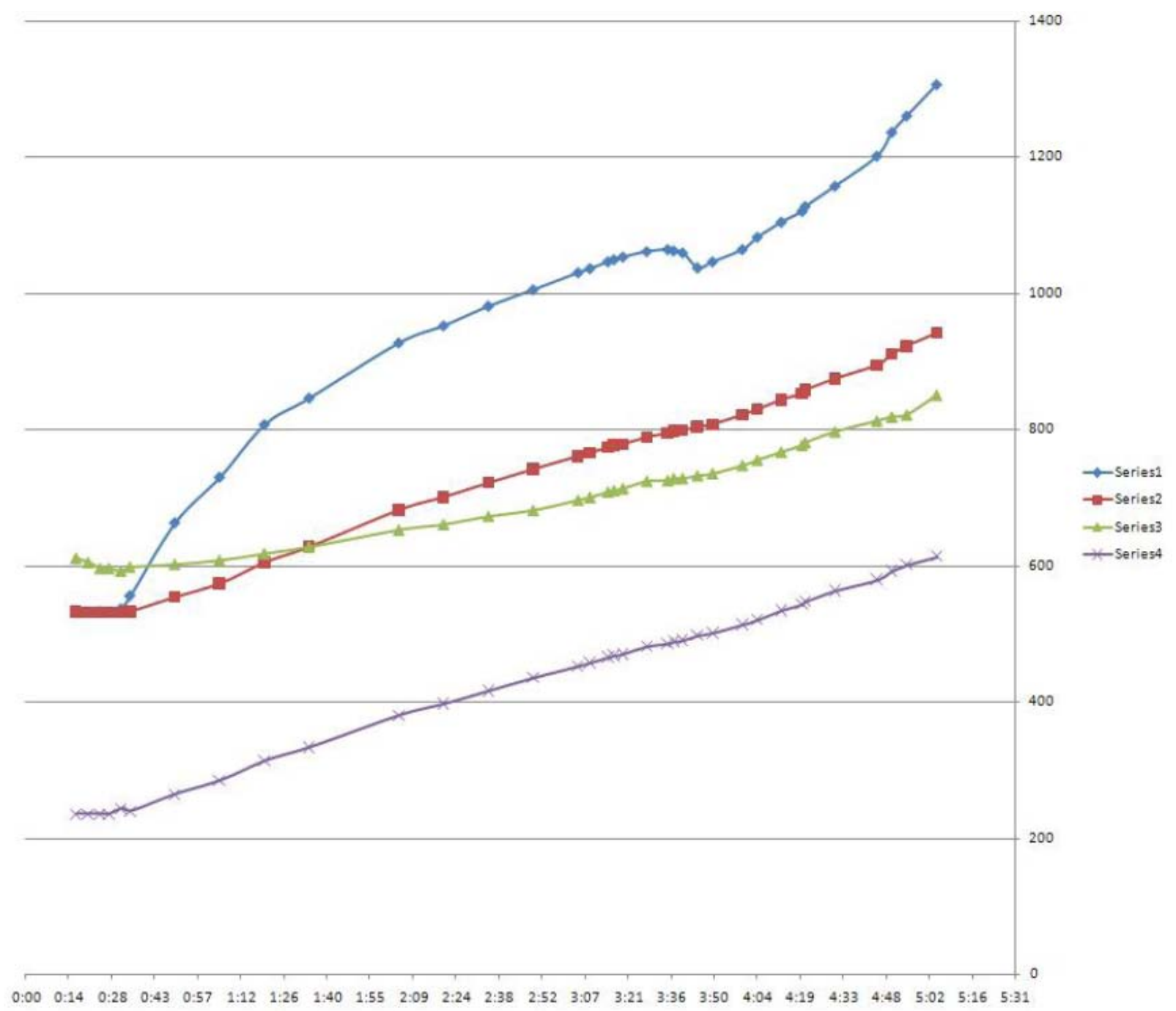



Appendix E

Aspen Model Flow Chart 



\section{Appendix E - Aspen Model Flow Chart}

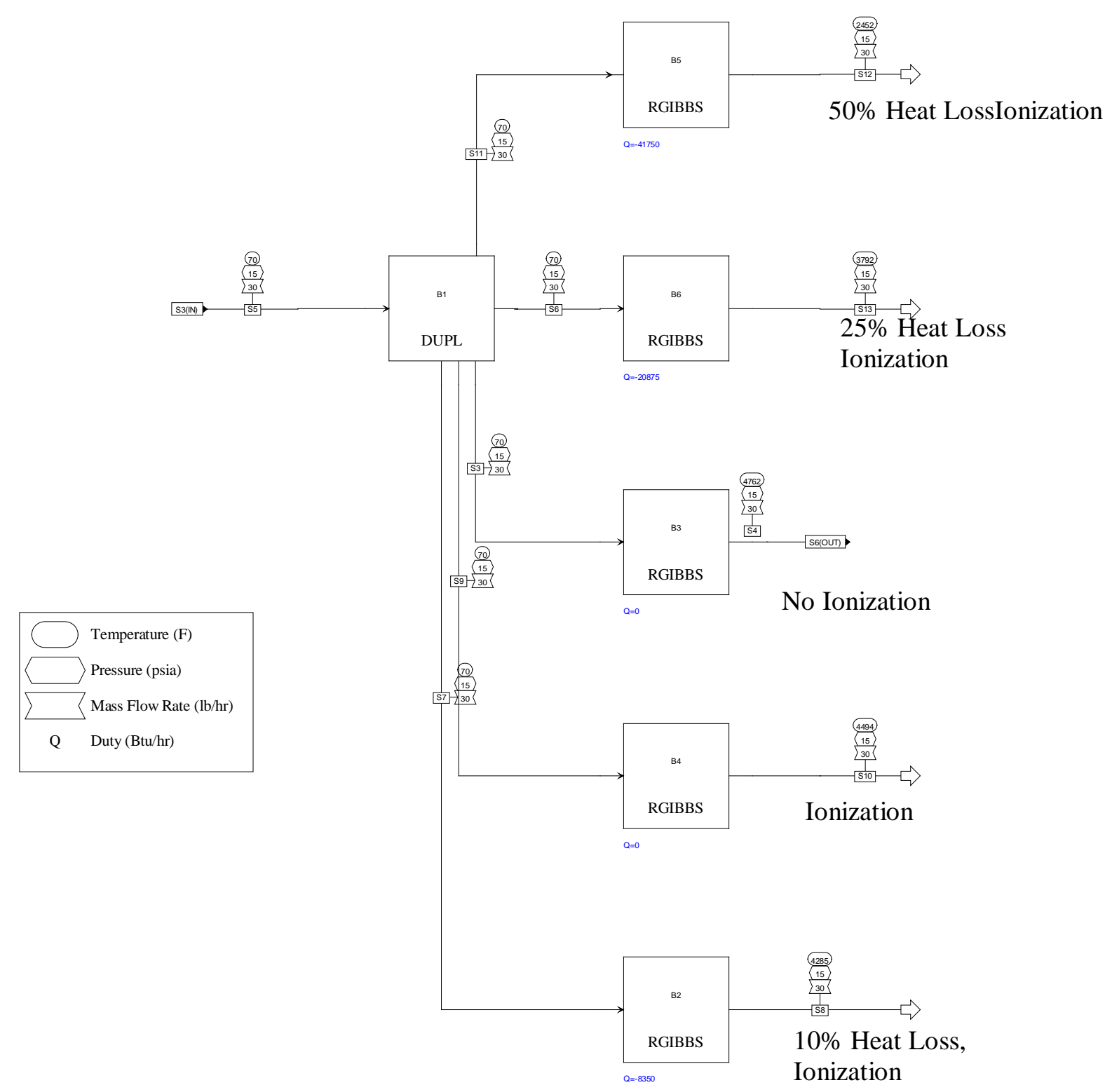





\section{Appendix F}

\section{Harbison-Walker Calculations}





\section{Appendix F - Harbison-Walker Calculations}

Harbison-Walker Refractories Company

\begin{tabular}{llll} 
& & APGreen & \\
\hline Customer: & PNNL & Date: & Sep 18, 2009 \\
Vessel Type: & gasifier & Shell Geometry: & Vertical Cylinder \\
Hydrogen Atmosphere: & $\mathbf{0} \%$ & Thermal Dimensions: & Outside Diameter: 1.33 (ft)
\end{tabular}

\begin{tabular}{|c|c|c|c|c|c|c|}
\hline Hot Face Temp $\left({ }^{\circ} \mathrm{F}\right)$ & Materia & & hickness (in) & K-Value & Mean Temp $\left({ }^{\circ} \mathrm{F}\right)$ & Resistivity \\
\hline 2539 & Aurex & & 2.00 & 59.49 & 2520 & 0.1147 \\
\hline 2500 & KAST- & *WARNING** & 3.00 & 2.39 & 2149 & 2.0754 \\
\hline 1799 & BTU-B & & 1.00 & 0.24 & 1006 & 4.6887 \\
\hline 213 & $304 \mathrm{Sta}$ & & 0.50 & 105.88 & 212 & 0.0049 \\
\hline Heat Flux: & 338.12 & Shell Temp: & 212 & & & \\
\hline Ambient Temp: & 75 & Wind Velocity: & 0.00 & & & \\
\hline Vessel Temp: & 2539 & Cold Face Emmissivity: & 0.91 & & & \\
\hline
\end{tabular}

Manufacturer's Suggested Maximum Service Temperature Is Being Exceeded.

The Values Shown Here Were Calculated Based on the Method Prescribed in ASTM C680 

Appendix G

Certificate of Analysis 



\section{Appendix G - Certificate of Analysis}

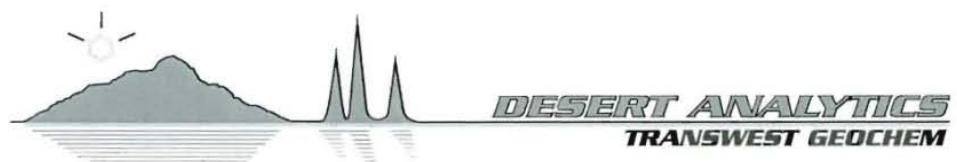

August 162007

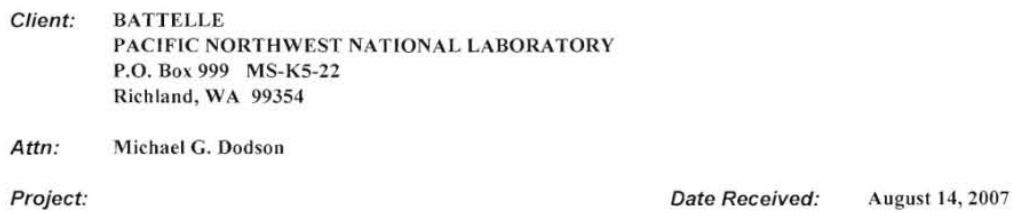

Certificate of Analysis

\begin{tabular}{|c|c|c|c|c|c|}
\hline Analyses & Method & units & $\begin{array}{c}1 \\
\text { DA07-7482 } \\
\end{array}$ & $\begin{array}{c}\# 131 \\
\text { DA07-7483 }\end{array}$ & $\begin{array}{c}\# 132 \\
\text { DA07-748 }\end{array}$ \\
\hline Proximate Analysis & D3172-89 & & & & \\
\hline Moisture & & $\%$ & 0.52 & 0.51 & 0.50 \\
\hline Volatile Matter & & $\%$ & 16.55 & 16.55 & 17.30 \\
\hline Fixed Carbon & & $\%$ & 72.60 & 72.64 & 71.88 \\
\hline Ash & & $\%$ & 10.86 & 10.81 & 10.81 \\
\hline Ultimate & D3176-89 & & & & \\
\hline Carbon & & $\%$ & 79.17 & 78.74 & 79.53 \\
\hline Hydrogen & & $\%$ & 4.32 & 4.06 & 4.06 \\
\hline Nitrogen & & $\%$ & 1.57 & 1.60 & 1.58 \\
\hline Oxygen & & $\%$ & 4.10 & 4.50 & 3.94 \\
\hline Sulfur & & $\%$ & 0.583 & 0.618 & 0.590 \\
\hline
\end{tabular}

2-3 Day Rush

Notes:

Values reported on an Moisture Free basis

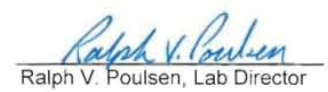

3860 S. Palo Verde Rd. Suite 303

Tucson, AZ 85714

520.623.3381

Page 1 of 1

Rpt-7482 Battelle Dodson, 8/16/2007 

Appendix $\mathrm{H}$

Moyno Results 



\section{Appendix H - Moyno Results}

\section{H.1 Page 1}

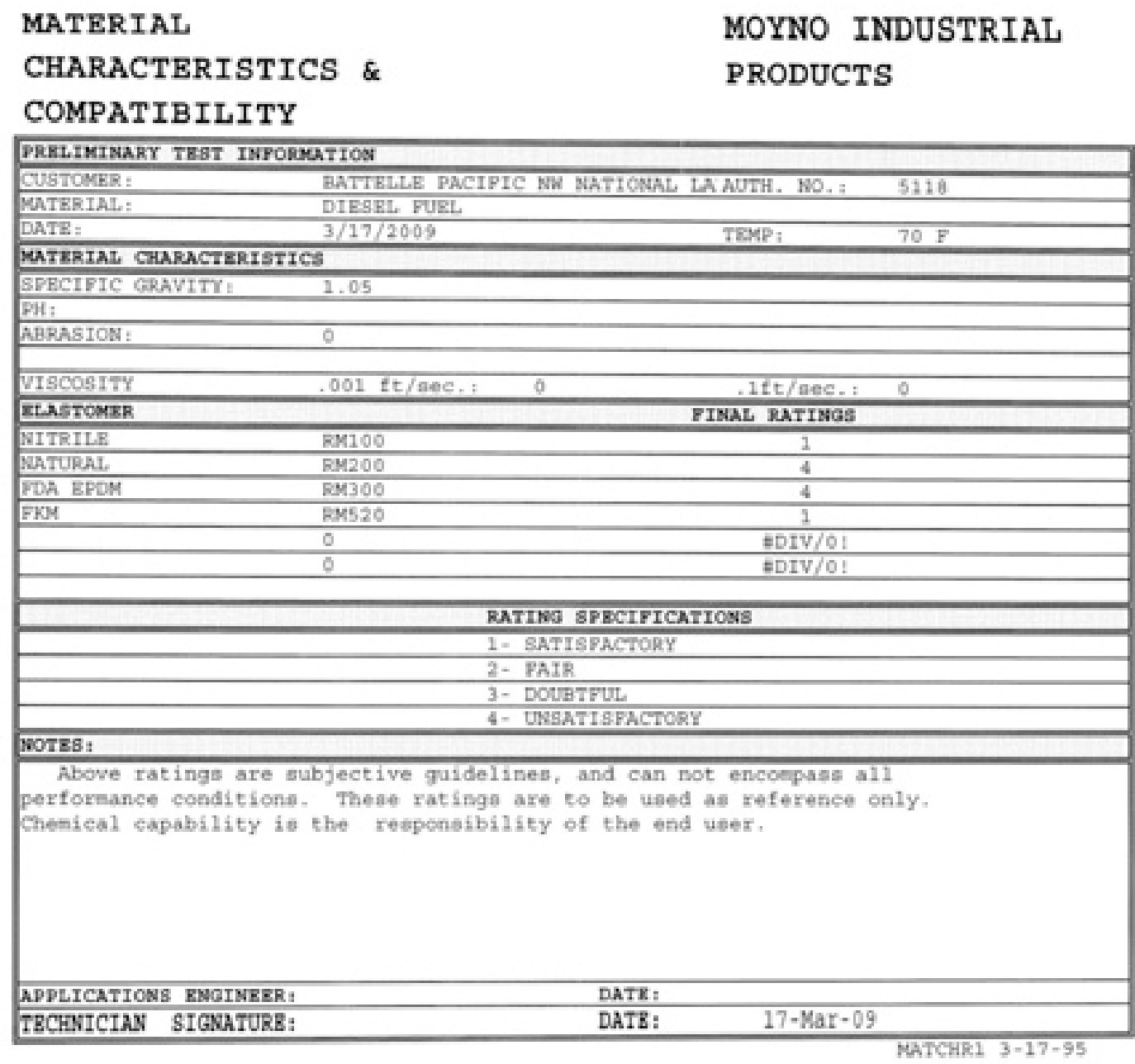




\section{H.2 Page 2}

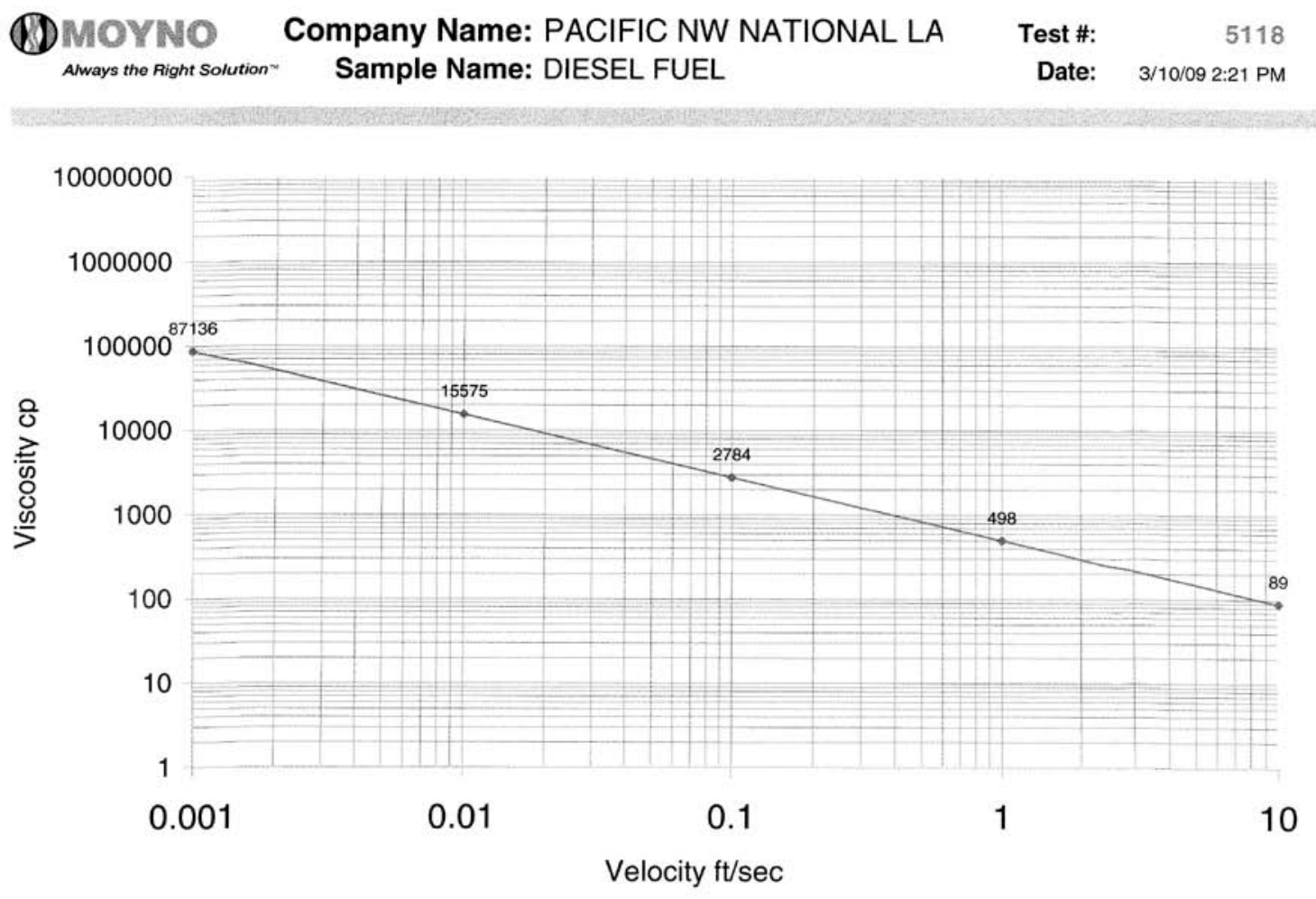

Temp Deg F: 70

Specific Gravity: 1.05 


\section{Appendix I}

\section{Aurex 70 Castable Data Sheets}





\section{Appendix I - Aurex 70 Data Sheets}

\section{I.1 Page 1}

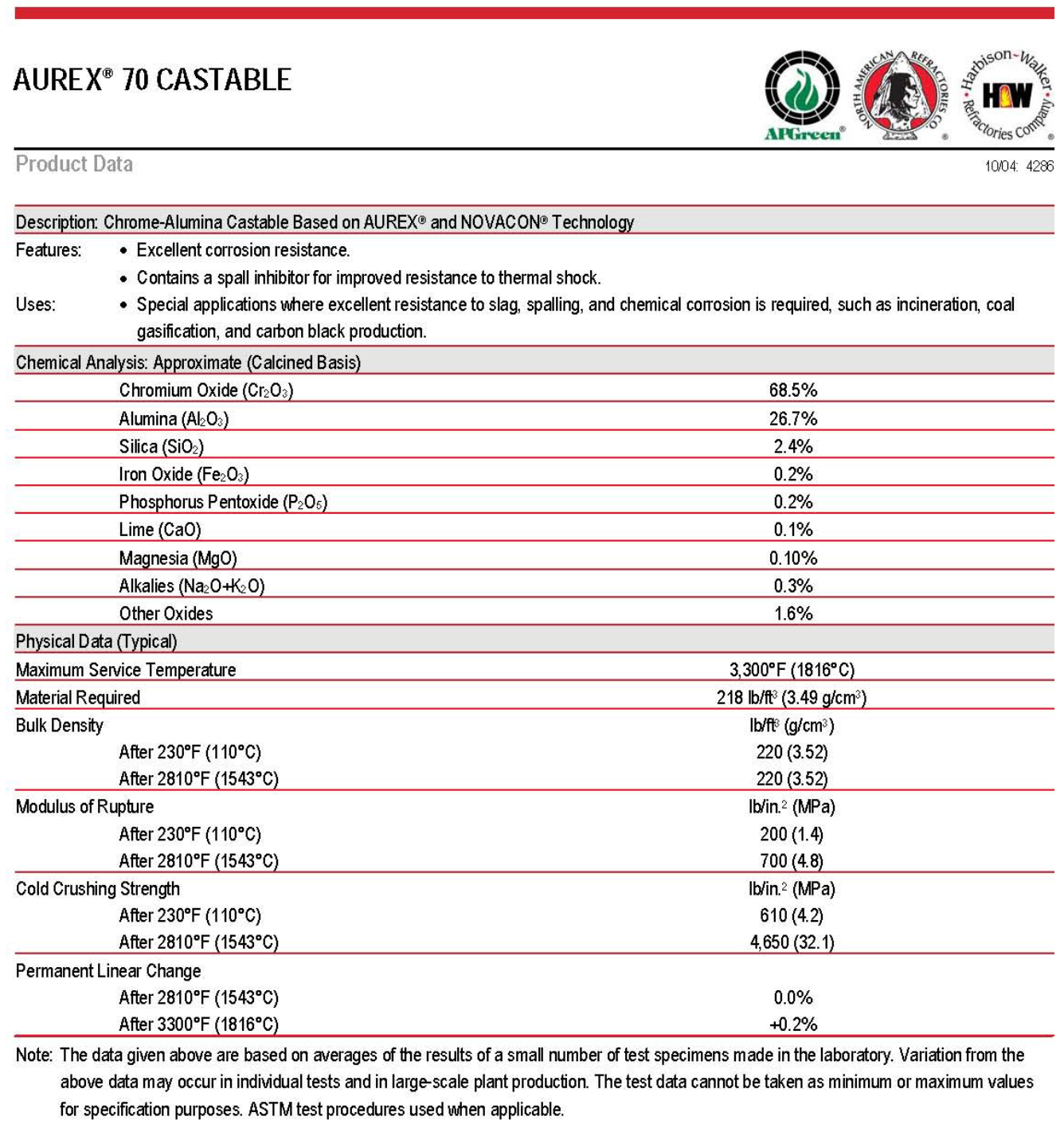




\section{I.2 Page 2}

\begin{tabular}{|c|c|c|c|}
\hline AUREX $^{\circledR} 70$ CASTABLE & & & $(7)$ \\
\hline Product Data & & & \\
\hline Mixing and Using Information (Water calculated at $8.337 \mathrm{lb} /$ gallon) & $55 \mathrm{lb}$ bag & $1000 \mathrm{lb} \mathrm{bag}$ & $1500 \mathrm{lb}$ bag \\
\hline Water Required-Vibration Casting (Weight $5.0 \%$ ) & & & \\
\hline Pounds & 2.8 & 50 & 75 \\
\hline Gallons & 0.3 & 6.0 & 9.0 \\
\hline Liters & 1.2 & 22.7 & 34.0 \\
\hline For detailed mixing and using instructions, contact your ANH repres & sit wown.anh & com. & \\
\hline Heatup/Dryout Schedule & & & \\
\hline See ANH Dryout Schedule 11-NOVACON PRODUCTS. & & & \\
\hline Installation Guidelines & & & \\
\hline See ANH Installation Guidelines LCC-3-Low Cement Castables- & & & \\
\hline Shelf Life (Under Proper Storage Conditions) & & 90 days & \\
\hline
\end{tabular}


Appendix J

KAST-O-LITE Data Sheets 



\section{Appendix J - KAST-O-LITE Data Sheets}

\section{J.1 Page 1}

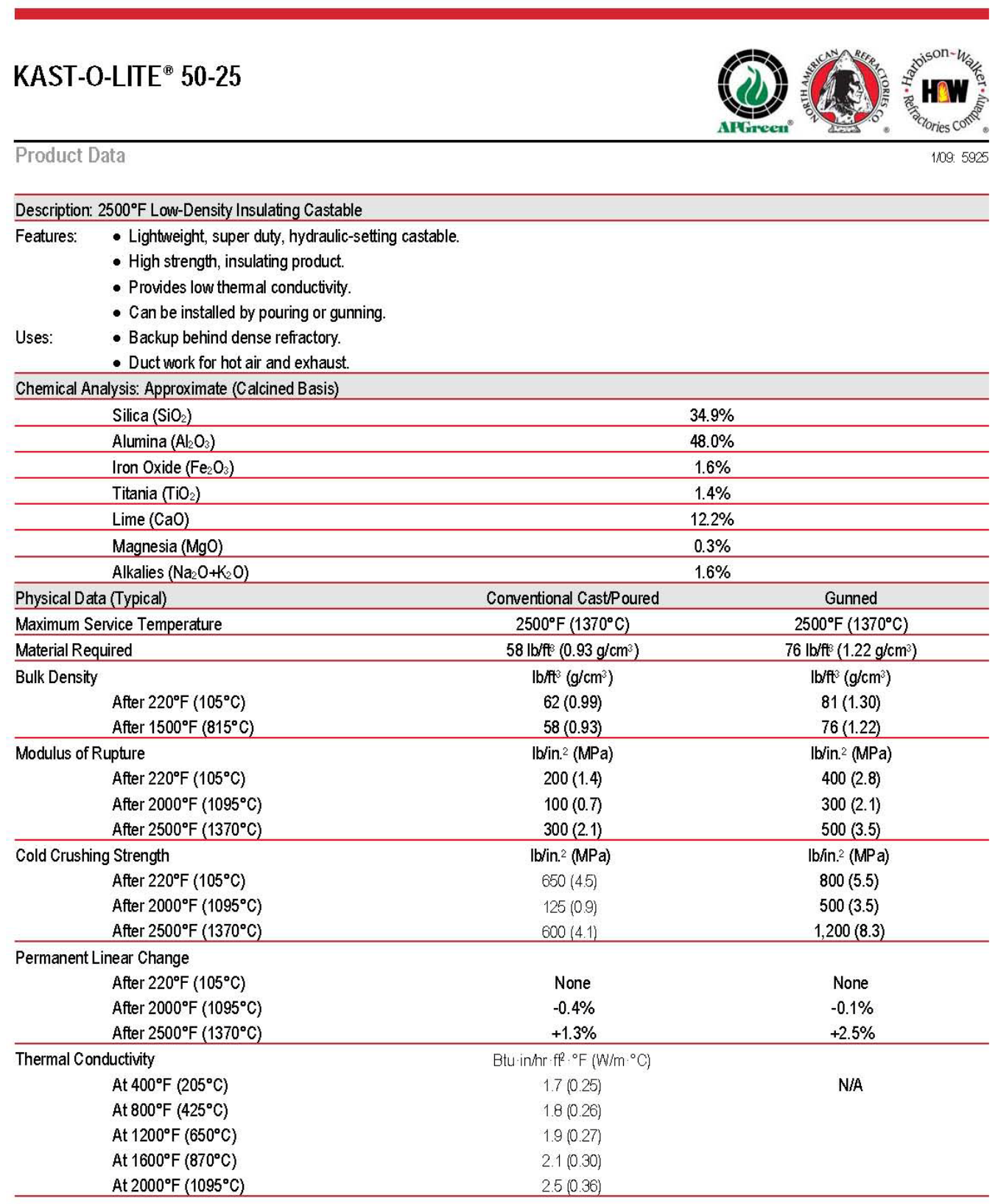

Note: The test data shown are based on average results on production samples and are subject to normal variation on individual tests. The test data cannot be taken as minimum or maximum values for specification purposes. ASTM test procedures used when applicable. 


\section{J.2 Page 2}

\begin{tabular}{|c|c|c|c|}
\hline \multicolumn{4}{|l|}{ Product Data } \\
\hline Mixing and Using Instructions (Water calculated at $8.337 \mathrm{lb} /$ gallon) & $55 \mathrm{lb}$ bag & $1000 \mathrm{lb}$ bag & $1500 \mathrm{lb}$ bag \\
\hline \multicolumn{4}{|l|}{ Water Required-Hand Casting (Weight $45.0 \%$ ) } \\
\hline Pounds & 24.8 & 450.0 & 675.0 \\
\hline Gallons & 3.0 & 54.0 & 81.0 \\
\hline $\begin{array}{c}\text { Liters } \\
\end{array}$ & 11.2 & 203.9 & 305.9 \\
\hline \multicolumn{4}{|l|}{ Water Required-Predampening for Gunning (W/Veight $13.0 \%$ ) } \\
\hline Pounds & 7.2 & 130.0 & 195.0 \\
\hline Gallons & 0.9 & 15.6 & 23.4 \\
\hline Liters & 3.2 & 58.9 & 88.4 \\
\hline \multicolumn{4}{|c|}{ For detailed mixing and using instructions, contact your ANH representative or visit wmw.anhrefractories.com. } \\
\hline \multicolumn{4}{|c|}{ Heatup/Dryout Schedule } \\
\hline \multicolumn{4}{|c|}{ See ANH Dryout Schedule 3-Standard Insulating Castables and Gunning Castables. } \\
\hline \multicolumn{4}{|c|}{ Installation Guidelines } \\
\hline \multicolumn{4}{|c|}{ See ANH Installation Guidelines IC-3-Insulating Castables-Castable/Gunnable. } \\
\hline Shelf Life (Under Proper Storage Conditions) & & 365 days & \\
\hline
\end{tabular}


Appendix K

\section{BTU-BLOCK Data Sheets}





\section{Appendix K - BTU-BLOCK Data Sheets}

\section{K.1 Page 1}

\section{(1T) Thermal Ceramics}

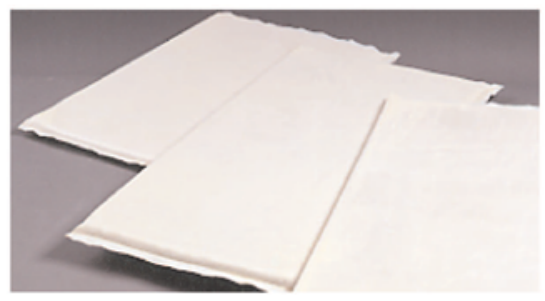

BTU-BLOCK products are a family of microporous insulation designed for use in high temperature industrial applications. Microporous insulation is a very high thermal efficiency material which has a thermal conductivity less than that of still air These materials, consisting of fine diameter heat resistant particles, reinforcement fibers and high temperature radiation blockers, address the primary modes of heat transfer in a novel way compared to traditional refractories. These components are appropriately sized and configured to create a microporous structure. This structure limits the number and movements of air particles, and creates a material of exceptionally low thermal conductivity. At elevated temperatures, the radiation blockers are employed to minimize radiation heat transfer by again proper sizing and distribution.

- Minimizing heat loss relates simply to energy saving, or reheat issues. For example, steel ladles containing back-up microporous insulation have substantially less solidified steel remaining in the ladle after the casting process is complete.

- Consistency of operating temperature, which results in a more consistent final product or an easier process to regulate and control.

- Minimum space requirements for an equivalent temperature drop across the insulation component, microporous material may need as little as $1 / 4$ the thickness compared to traditional fibrous material (at elevated temperatures).

BTU-BLOCK Panel consists of BTU-BLOCK Board encapsulated in a high temperature textile. The exterior fabric maximizes the strength of the panel while providing a lightweight, low thermal conductivity finished product. The textile also offers mechanical protection, flexural strength and an excellent substrate for bonding the panels to walls or other insulation. These panels are easily cut to shape, however the cut edge should be sealed if the part is to undergo any movement.

Standard BTU-BLOCK Panel $1208 / 16$ consists of a $1200^{\circ} \mathrm{F}$ $\left(649^{\circ} \mathrm{C}\right)$ rated outer textile, while the core has a continuous use limit of $1800^{\circ} \mathrm{F}\left(982^{\circ} \mathrm{C}\right)$. By substituting a higher temperature cloth, such as a silica or quartz cloth, the use limit of the entire composite can be increased to $1800^{\circ} \mathrm{F}\left(982^{\circ} \mathrm{C}\right)$.

Degradation of the textile may not be a concern after initial installation depending on the application.

\section{BTU-BLOCK Panel 1208/16}

Product Information

\section{Features}

- Extremely low thermal conductivity and heat loss

- High compressive strength

- Fiberglass encapsulation provides flexural strength and sur-

face for bonding $\left(1200^{\circ} \mathrm{F}\left[649^{\circ} \mathrm{C}\right]\right.$ use limit)

- Special facing allows use limit up to $1800^{\circ} \mathrm{F}\left(982^{\circ} \mathrm{C}\right)$

\section{Applications}

- OEM

- High temperature industrial

- Fire protection

- Vending machines

- Appliances

Physical Characteristics

Core density, pcf $\left(\mathrm{kg} / \mathrm{m}^{3}\right)$

Standard panel size, in $(\mathrm{cm})$

Standard thicknesses, in $(\mathrm{cm})$

16 (256)

$24 \times 36(60 \times 90)$

$1 / 2-2$

$(\mathrm{cm})$

$(1.25,5.1)$

Note: Parts may be supplied in custom shapes and sizes to meet customer requirements. 


\section{K.2 Page 2}

\section{BTU-BLOCK Panel 1208/16}

Product Information

Physical Properties
Continuous use limit, up to ${ }^{\circ} \mathrm{F}\left({ }^{\circ} \mathrm{C}\right)$
Panel core
Glass cloth
Specialty fabric
Fired linear shrinkage, \% (ASTM C 356) 24 hrs
@ $1000^{\circ} \mathrm{F}\left(538^{\circ} \mathrm{C}\right)$
$@ 1500^{\circ} \mathrm{F}\left(815^{\circ} \mathrm{C}\right)$
@ $1750^{\circ} \mathrm{F}\left(954^{\circ} \mathrm{C}\right)$

Thermal Conductivity, Btu•in. $/ \mathrm{hr} \cdot \mathrm{ft}^{2} \cdot{ }^{\circ} \mathrm{F}(\mathrm{W} / \mathrm{m} \cdot \mathrm{k})$ ASTM C 201 Mean temperature
(Q) $500^{\circ} \mathrm{F}$
@ $1000^{\circ} \mathrm{F}$
$0.18(0.02)$
$0.23(0.03)$
(Q) $1500^{\circ} \mathrm{F}$
$0.31(0.04)$

Compression Resistance, ASTM C 165

Deformation 16 pcf material, psi (Mpa)

$10 \%$

$20 \%$

$800^{\circ} \mathrm{F}\left(982^{\circ} \mathrm{C}\right)$

$1200^{\circ} \mathrm{F}\left(649^{\circ} \mathrm{C}\right)$

$1800^{\circ} \mathrm{F}\left(982^{\circ} \mathrm{C}\right)$

0.3

0.6
1.0

$30 \%$

$173(1.19)$

$315(2.17)$

$458(3.16)$

$40 \%$

$641(4.42)$

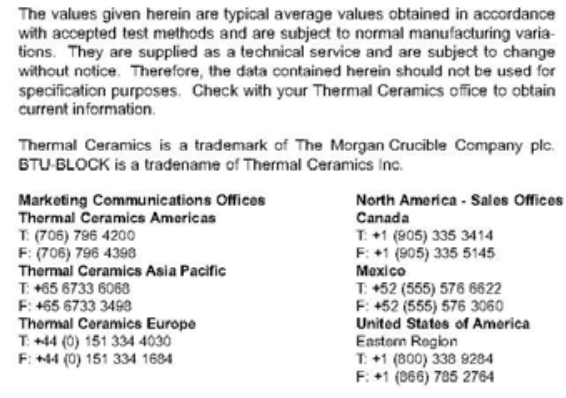

Western Region

T: +1 (1866) 7852738
F: +1 (866) 7852760

South America - Sales Offices

Argentina 4.54 (11) 43734439

F: +54 (11) 43723331

razil $+55(21) 24181366$

$1+55(21) 24181366$
$F:+55$ (21) 24181205
Chile
$\mathrm{T}:+56$ (2) 854
1084

T: +56 (2) 8541084
$\mathrm{~F}:+56$ (2) 8541952

Colombia

$\mathrm{T}+57$ (2) 2282935/2282803/2282758

F: +57 (2) 2282935/2282003/2372208

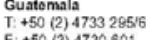

Vonezuela

T: +50 (241) a78 3164

www.thermalceramics.com 
Appendix L

Oxygen Flow Calibration Curve 



\section{Appendix L - Oxygen Flow Calibration Curve}

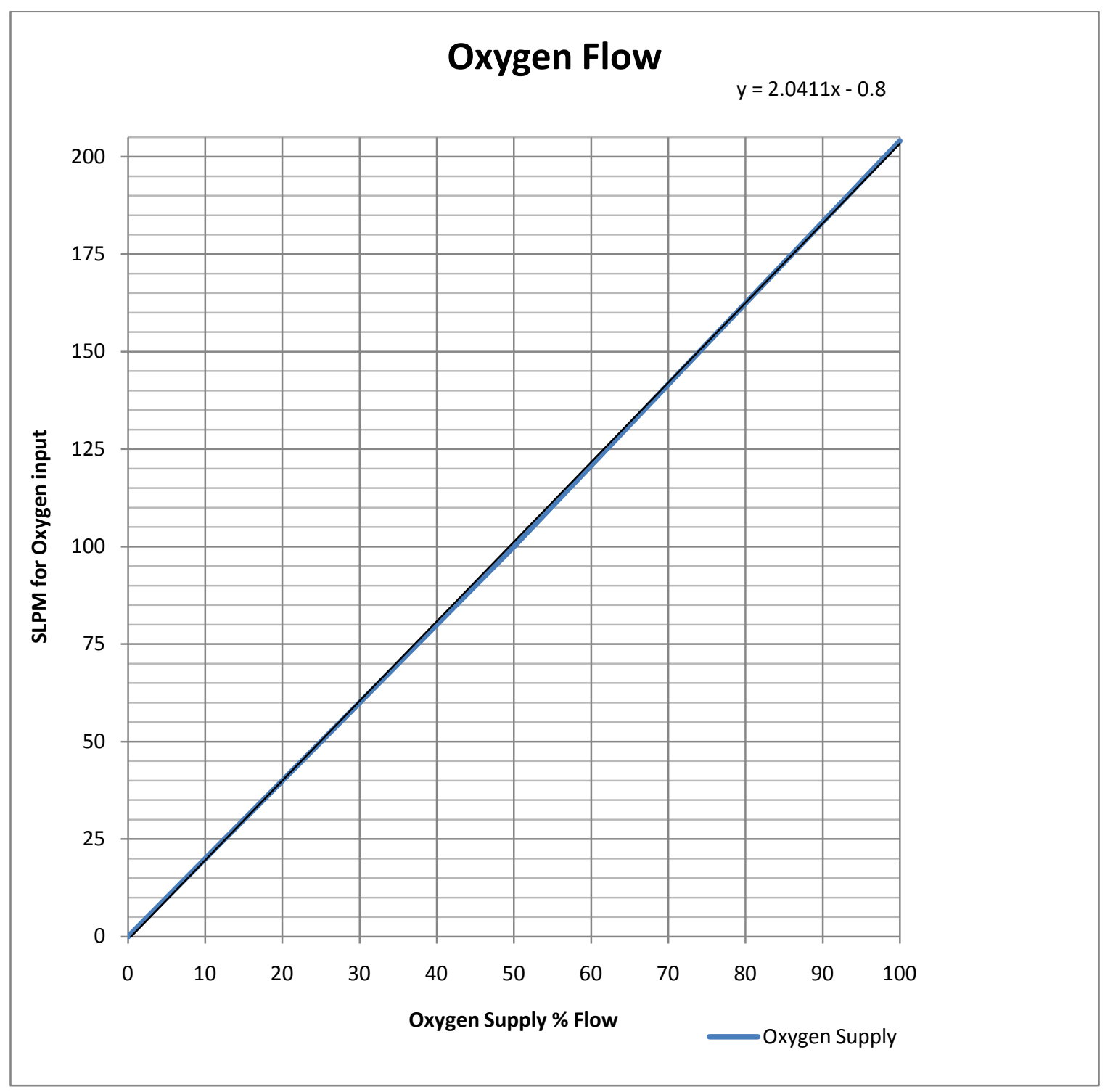





\section{Appendix M}

\section{Methanol Pump Calibration Curve}





\section{Appendix M - Methanol Pump Calibration Curve}

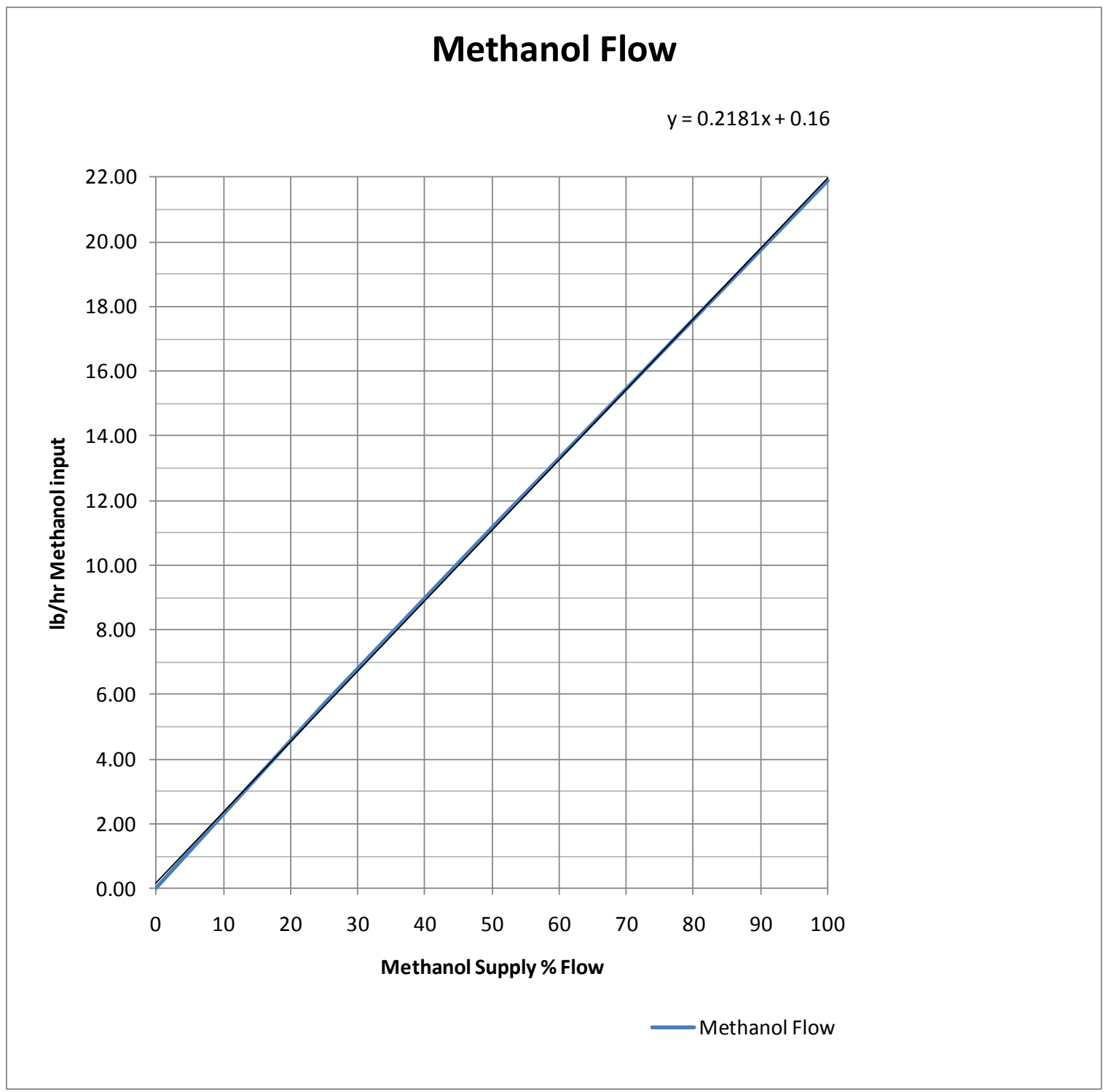



Appendix N

\section{Coal Auger Calibrated Flow Curve}





\section{Appendix N - Coal Auger Calibrated Flow Curve}

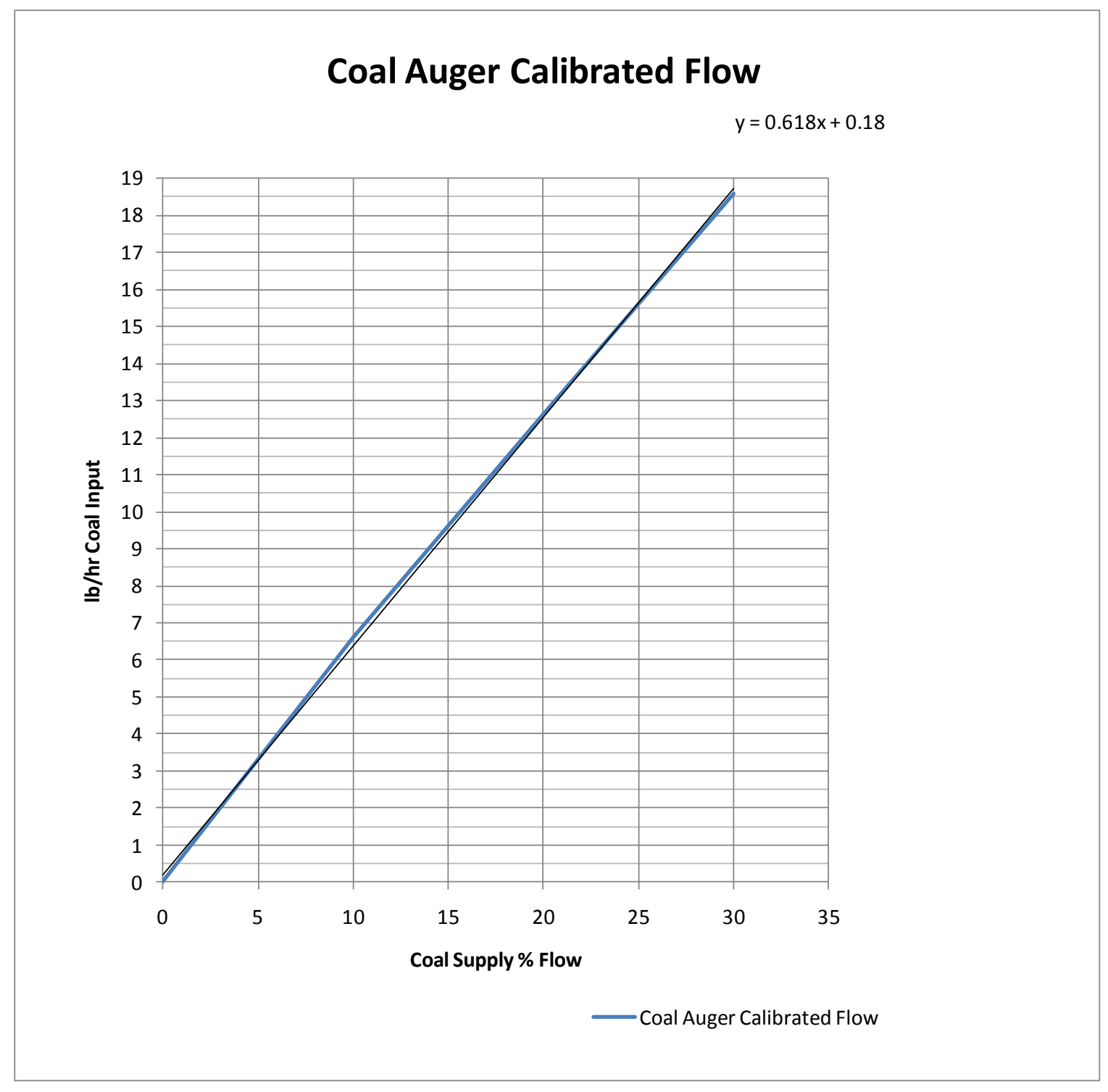





\section{Appendix 0}

\section{Sensitivity Analysis for Methanol Input Change}





\section{Appendix 0 - Sensitivity for Methanol Input Change}

Table 0.1. E85 (Methanol Substitute) Fuel Sensitivity Data

\begin{tabular}{|c|c|c|c|c|c|c|c|c|}
\hline \multirow{2}{*}{$\begin{array}{c}\begin{array}{c}\text { Time } \\
\text { interval }\end{array} \\
\text { Minutes }\end{array}$} & \multirow{2}{*}{$\begin{array}{c}\text { Input } \\
\\
\text { E85 } \\
\text { Fuel \% } \\
\end{array}$} & \multicolumn{5}{|c|}{ Output Syngas } & \multicolumn{2}{|c|}{ Output syngas ratios } \\
\hline & & $\begin{array}{c}\mathrm{CO} \\
\%\end{array}$ & $\begin{array}{c}\mathrm{CO}_{2} \\
\%\end{array}$ & $\underset{\%}{\mathrm{CH}_{4}}$ & $\begin{array}{c}\mathrm{H} 2 \\
\%\end{array}$ & $\begin{array}{c}\text { inert } \\
\text { constituent } \\
\% \\
\end{array}$ & $\begin{array}{c}\mathrm{CO} /\left(\mathrm{CO}+\mathrm{CO}_{2}\right) \\
\% \text { ratio }\end{array}$ & $\begin{array}{c}\mathrm{CO} / \mathrm{H}_{2} \\
\% \\
\text { ratio } \\
\end{array}$ \\
\hline 0 & 20 & 9.7 & 25.8 & 20 & 7.4 & 37.1 & 0.27 & 1.31 \\
\hline 5 & 21 & 10.5 & 25.4 & 19.5 & 8.4 & 36.2 & 0.29 & 1.25 \\
\hline 10 & 22 & 12.5 & 23.7 & 20 & 10 & 33.8 & 0.35 & 1.25 \\
\hline 15 & 23 & 15 & 22.4 & 18.9 & 12 & 31.7 & 0.40 & 1.25 \\
\hline 20 & 24 & 17.5 & 20.4 & 18.4 & 14 & 29.7 & 0.46 & 1.25 \\
\hline
\end{tabular}

Table O.2. E85 (methanol substitute) Fuel Sensitivity Summary

\begin{tabular}{|c|c|c|c|c|c|c|c|c|}
\hline \multirow{2}{*}{$\begin{array}{c}\begin{array}{c}\text { Time } \\
\text { interval }\end{array} \\
\text { Minutes }\end{array}$} & \multicolumn{2}{|l|}{$\begin{array}{c}\text { Total } \\
\text { input } \\
\text { change }\end{array}$} & \multicolumn{4}{|c|}{ Output syngas change } & \multicolumn{2}{|c|}{$\begin{array}{c}\text { Output syngas ratio } \\
\text { changes }\end{array}$} \\
\hline & $\begin{array}{c}\text { E85 Fuel } \\
\% \\
\end{array}$ & $\begin{array}{c}\text { CO } \\
\%\end{array}$ & $\begin{array}{c}\mathrm{CO}_{2} \\
\%\end{array}$ & $\begin{array}{c}\mathrm{CH}_{4} \\
\%\end{array}$ & $\begin{array}{c}\text { H2 } \\
\% \\
\end{array}$ & $\begin{array}{c}\text { inert } \\
\text { constituent } \\
\% \\
\end{array}$ & $\begin{array}{c}\mathrm{CO} /\left(\mathrm{CO}+\mathrm{CO}_{2}\right) \\
\% \text { ratio } \\
\end{array}$ & $\begin{array}{c}\mathrm{CO} / \mathrm{H}_{2} \\
\% \\
\text { ratio } \\
\end{array}$ \\
\hline 20 & 4 & 7.8 & -5.4 & -1.6 & 6.6 & -7.4 & 0.189 & -0.061 \\
\hline
\end{tabular}

Table O.3. E85 (methanol substitute) Fuel Sensitivity Temperature Profile

\begin{tabular}{ccccc}
\hline $\begin{array}{c}\text { Time } \\
\text { interval }\end{array}$ & \multicolumn{4}{c}{$\begin{array}{c}\text { Thermocouple Output Temperature } \\
\text { (degrees Celsius) }\end{array}$} \\
\hline Minutes & TC 1 & TC 2 & TC 3 & TC 4 \\
\hline 0 & 943 & 715 & 493 & 264 \\
5 & 951 & 719 & 491 & 268 \\
10 & 965 & 723 & 492 & 272 \\
15 & 975 & 724 & 494 & 275 \\
20 & 984 & 727 & 492 & 278 \\
\hline
\end{tabular}


Table 0.4. Oxygen Input Sensitivity Data

\begin{tabular}{|c|c|c|c|c|c|c|c|c|}
\hline \multirow{2}{*}{$\begin{array}{c}\text { Time } \\
\text { interval }\end{array}$} & \multirow{2}{*}{$\begin{array}{c}\text { Input } \\
\begin{array}{c}\text { Oxygen } \\
\%\end{array} \\
\end{array}$} & \multicolumn{5}{|c|}{ Output Syngas } & \multicolumn{2}{|c|}{ Output syngas ratios } \\
\hline & & $\begin{array}{c}\text { CO } \\
\%\end{array}$ & $\begin{array}{c}\mathrm{CO}_{2} \\
\%\end{array}$ & $\begin{array}{c}\mathrm{CH}_{4} \\
\%\end{array}$ & $\begin{array}{c}\mathrm{H} 2 \\
\%\end{array}$ & $\begin{array}{c}\text { inert } \\
\text { constituent } \\
\% \\
\end{array}$ & $\begin{array}{c}\mathrm{CO} /\left(\mathrm{CO}+\mathrm{CO}_{2}\right) \\
\% \text { ratio }\end{array}$ & $\begin{array}{c}\mathrm{CO} / \mathrm{H}_{2} \\
\% \\
\text { ratio } \\
\end{array}$ \\
\hline 0 & 18 & 17.5 & 20.4 & 18.4 & 14 & 29.7 & 0.46 & 1.25 \\
\hline 5 & 19 & 18.6 & 19.2 & 18.9 & 15 & 28.3 & 0.49 & 1.24 \\
\hline 10 & 20 & 19.1 & 18.9 & 18.2 & 15.5 & 28.3 & 0.50 & 1.23 \\
\hline 15 & 20 & 20 & 19.1 & 15.7 & 16.3 & 28.9 & 0.51 & 1.23 \\
\hline
\end{tabular}

Table O.5. Oxygen Input Sensitivity Summary

\begin{tabular}{|c|c|c|c|c|c|c|c|c|}
\hline \multirow{2}{*}{$\begin{array}{c}\begin{array}{c}\text { Time } \\
\text { interval }\end{array} \\
\text { Minutes }\end{array}$} & \multirow{2}{*}{$\begin{array}{c}\begin{array}{c}\text { Total } \\
\text { input } \\
\text { change }\end{array} \\
\begin{array}{c}\text { Oxygen } \\
\%\end{array} \\
\end{array}$} & \multicolumn{5}{|c|}{ Output syngas change } & \multicolumn{2}{|c|}{$\begin{array}{c}\text { Output syngas ratio } \\
\text { changes }\end{array}$} \\
\hline & & $\begin{array}{c}\mathrm{CO} \\
\%\end{array}$ & $\begin{array}{c}\mathrm{CO}_{2} \\
\%\end{array}$ & $\begin{array}{c}\mathrm{CH}_{4} \\
\%\end{array}$ & $\begin{array}{c}\mathrm{H} 2 \\
\%\end{array}$ & $\begin{array}{c}\text { inert } \\
\text { constituent } \\
\% \\
\end{array}$ & $\begin{array}{c}\mathrm{CO} /\left(\mathrm{CO}+\mathrm{CO}_{2}\right) \\
\% \text { ratio }\end{array}$ & $\begin{array}{c}\mathrm{CO} / \mathrm{H}_{2} \\
\% \\
\text { ratio } \\
\end{array}$ \\
\hline 15 & 2 & 2.5 & -1.3 & -2.7 & 2.3 & -0.8 & 0.050 & -0.023 \\
\hline
\end{tabular}

Table O.6. Oxygen Input Sensitivity Temperature Profile

\begin{tabular}{|c|c|c|c|c|}
\hline \multirow{2}{*}{$\begin{array}{c}\text { Time } \\
\text { interval }\end{array}$} & \multicolumn{4}{|c|}{$\begin{array}{c}\text { Thermocouple Output Temperature } \\
\text { (degrees Celsius) }\end{array}$} \\
\hline & TC 1 & TC 2 & TC 3 & TC 4 \\
\hline 0 & 984 & 727 & 492 & 278 \\
\hline 5 & 993 & 730 & 491 & 282 \\
\hline 10 & 1001 & 730 & 489 & 284 \\
\hline 15 & 1014 & 732 & 489 & 287 \\
\hline
\end{tabular}




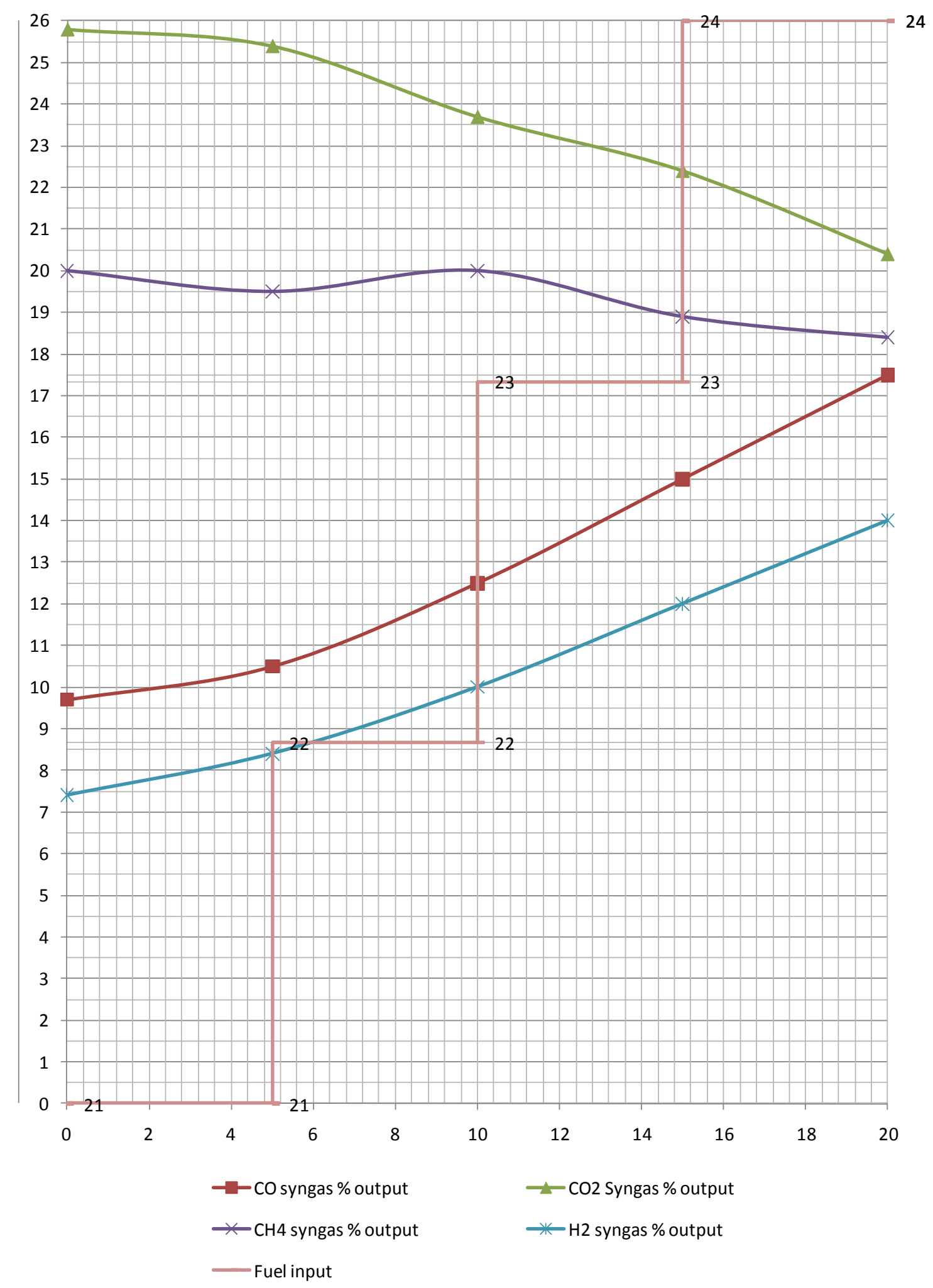

Figure O.1. Methanol Input Change versus Syngas Output 


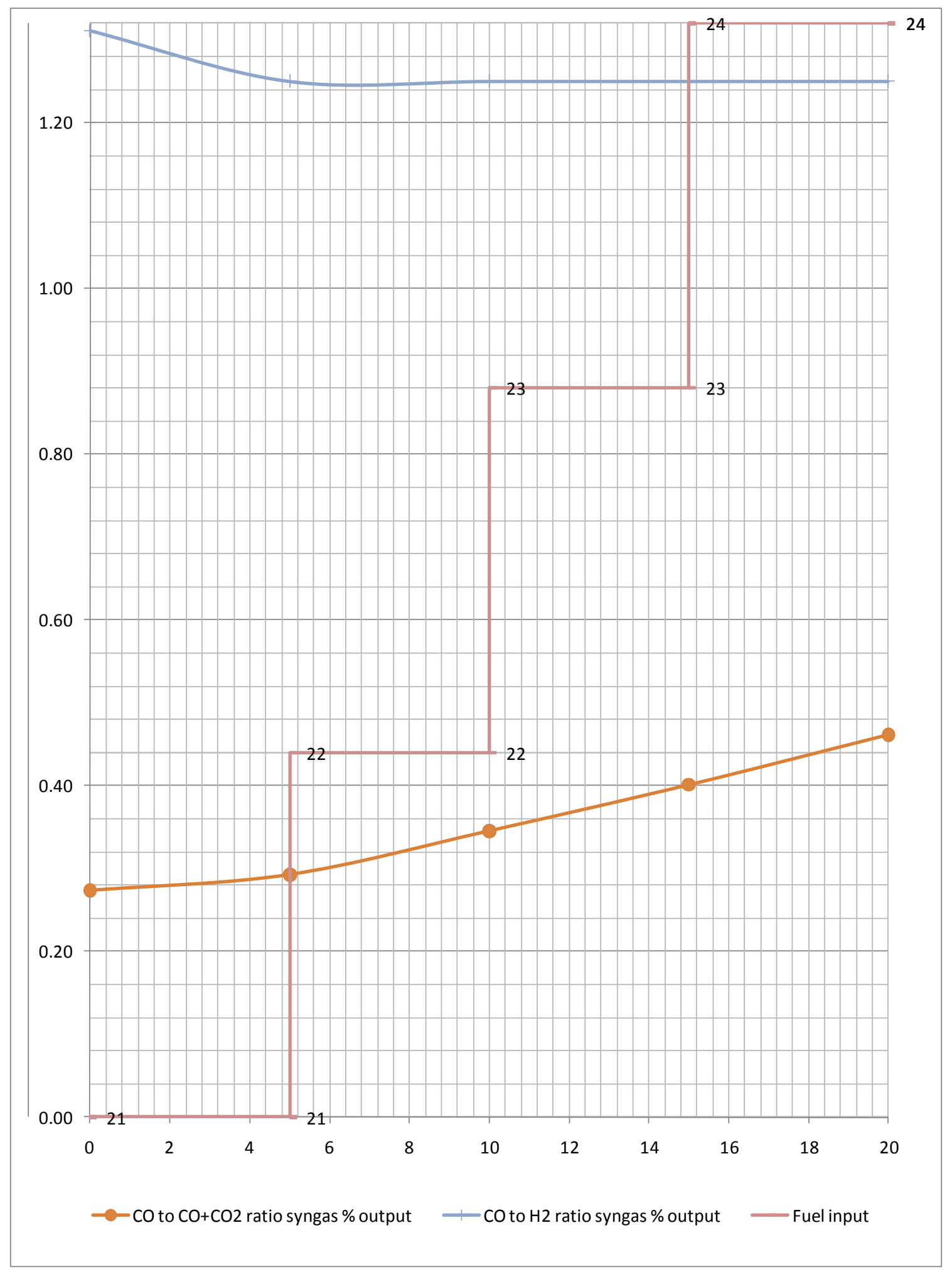

Figure O.2. Methanol Input Change versus Syngas Ratio Output 


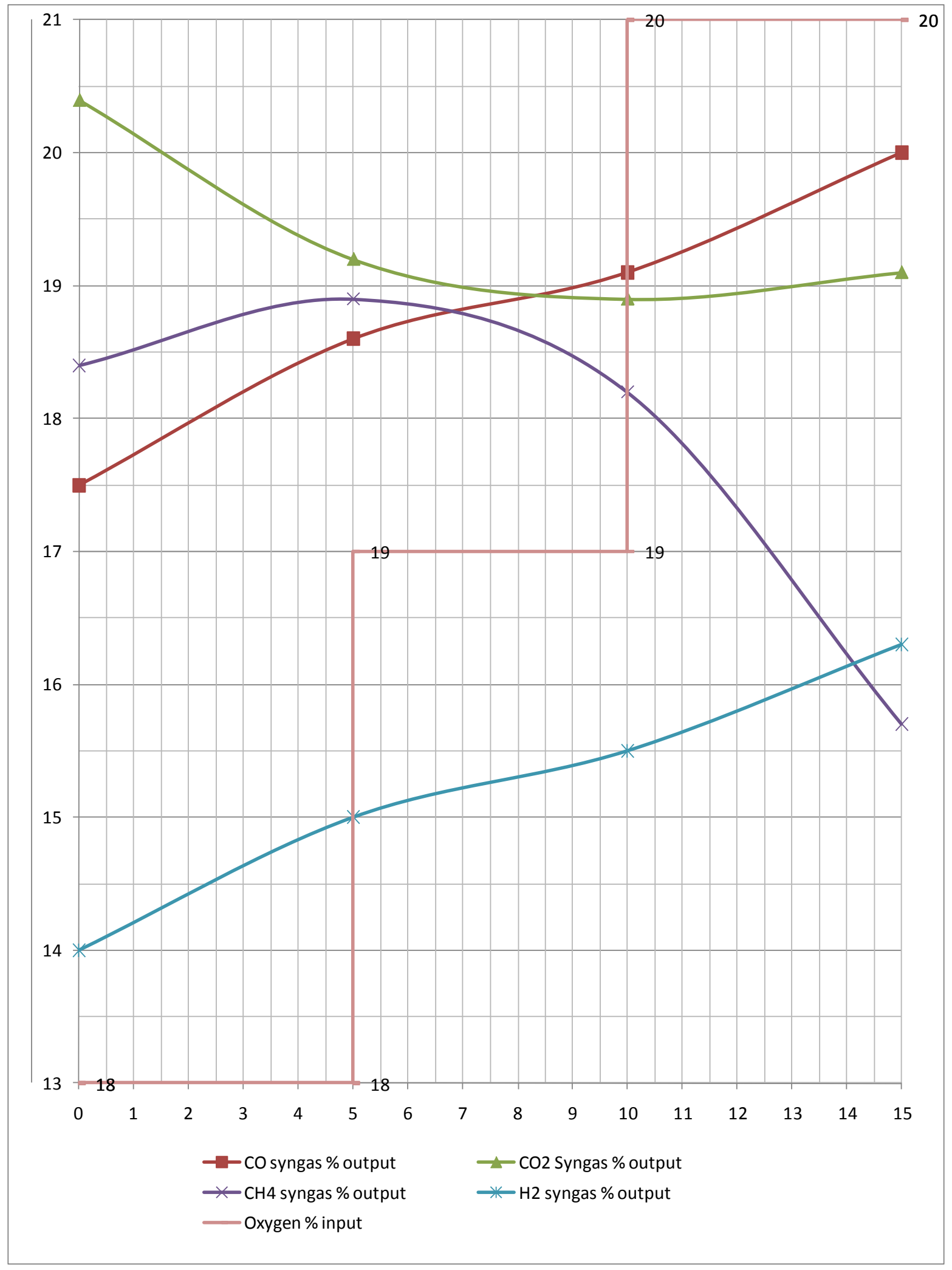

Figure 0.3. Oxygen Input Change versus Syngas Output 


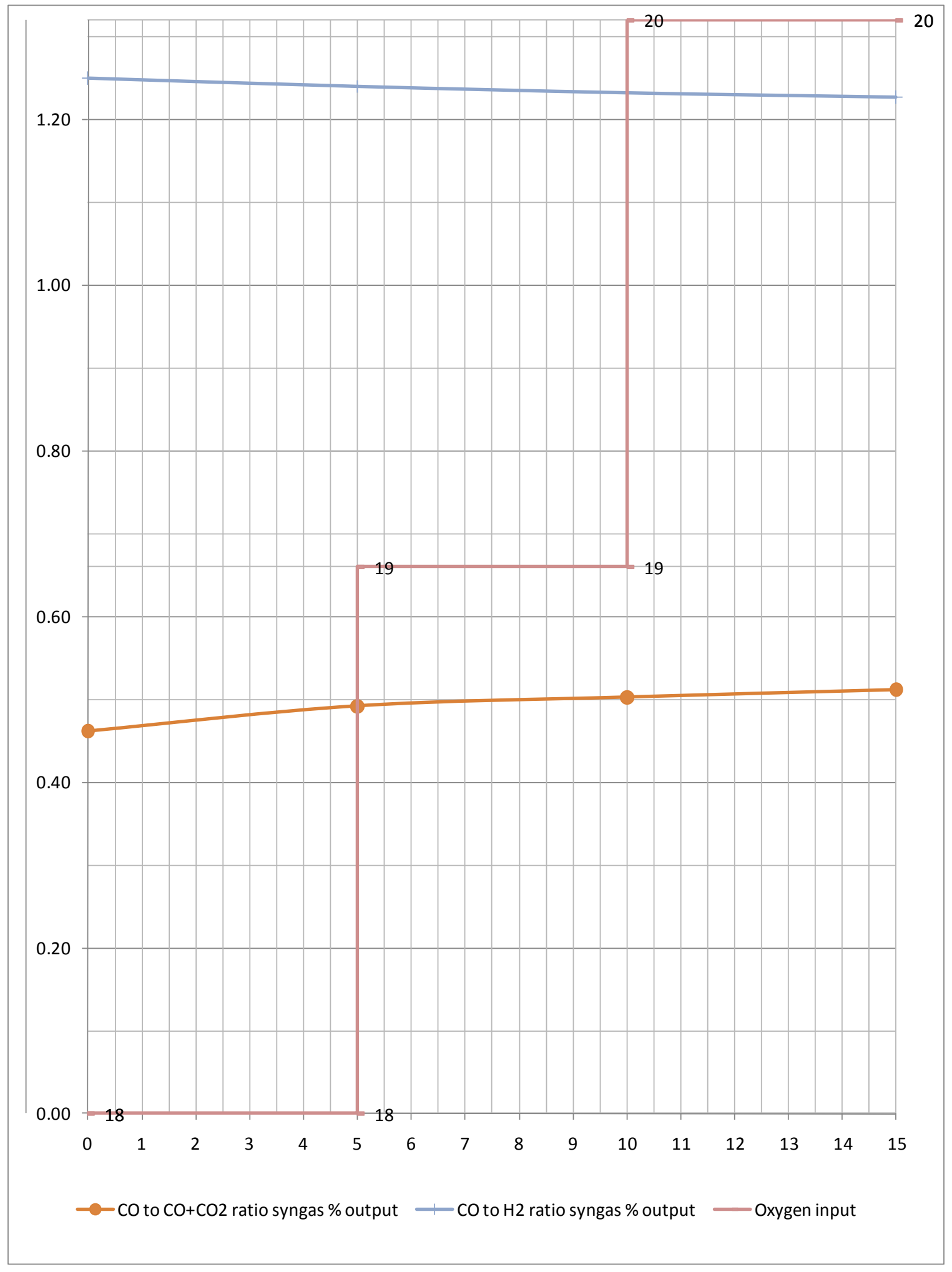

Figure 0.4. Oxygen Input Change versus Syngas Ratio Output 


\section{Distribution}

No. of

Copies

1 Local Distribution

Pacific Northwest National Laboratory

$\begin{array}{ll}\text { D Reid } & \text { PDF } \\ \text { MD Bearden } & \text { PDF } \\ \text { JE Cabe } & \text { PDF } \\ \text { TJ Samuel } & \text { PDF } \\ \text { RJ Robertus } & \text { PDF } \\ \text { ML Elliot } & \text { PDF }\end{array}$

Distr.1 




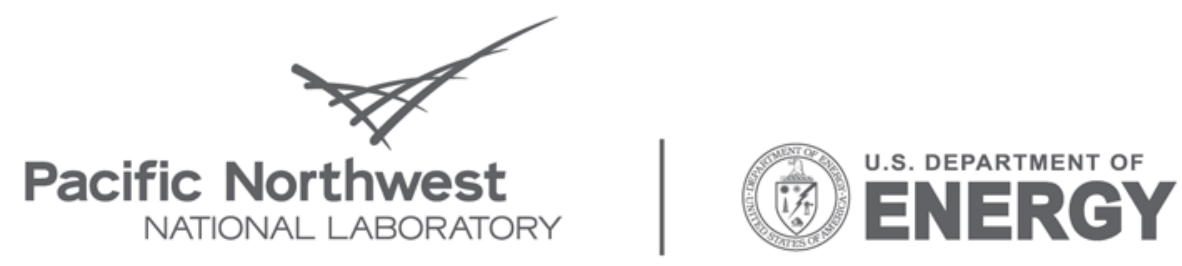

Proudly Operated by Battelle Since 1965

902 Battelle Boulevard

P.O. Box 999

Richland, WA 99352

1-888-375-PNNL (7665)

www.pnl.gov 